- $x_{10}$

(10)

(m) II)

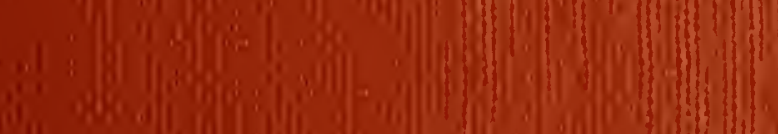

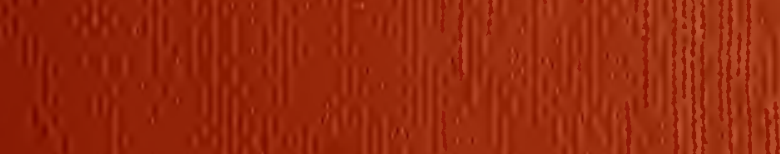

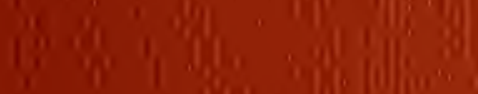

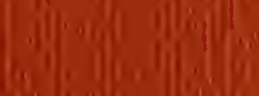

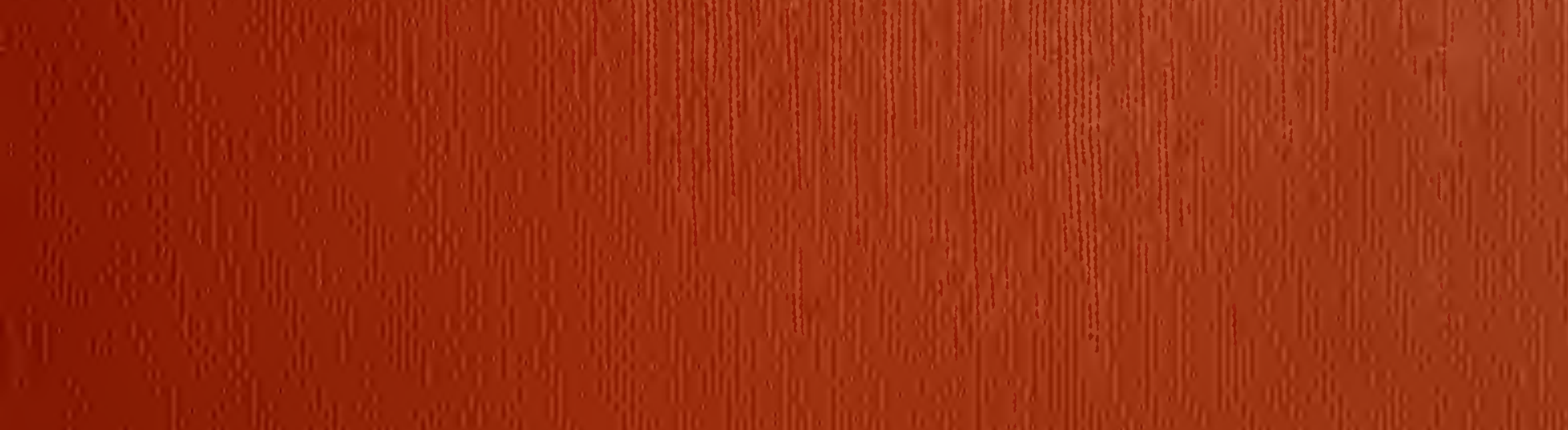

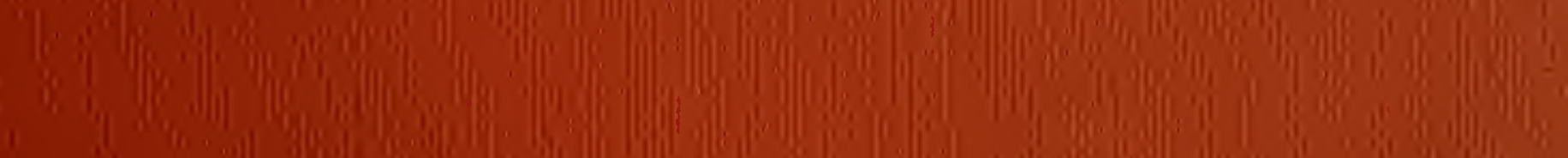

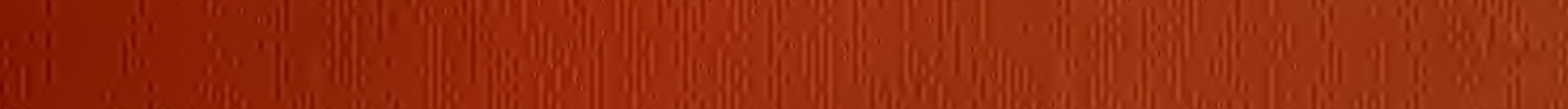

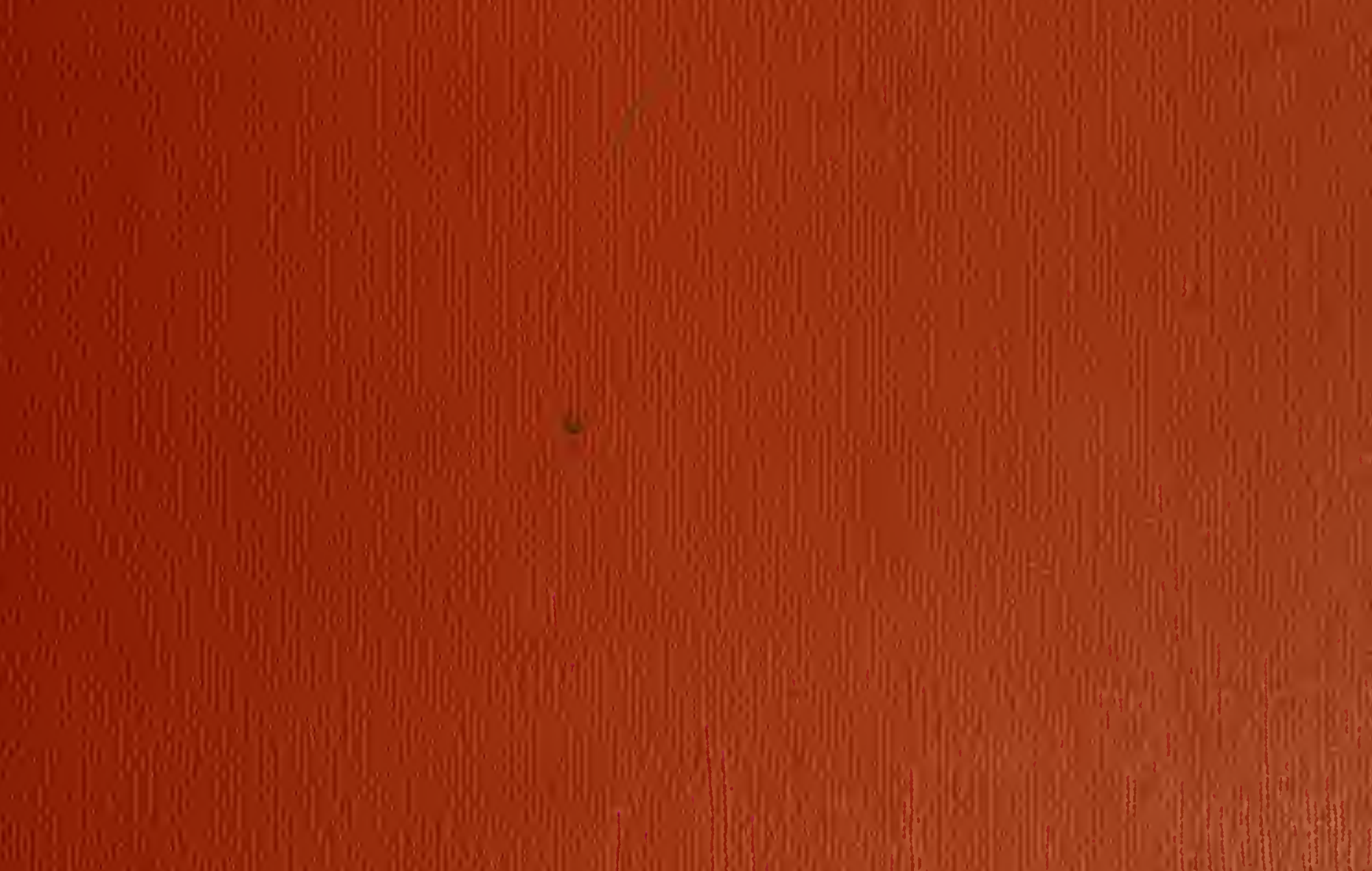



CARDEL

$$
\text { Banns }
$$





Memoirg of the Anseum of Comparative zodlogy

AT HARVARD COLLEGE.

VoL. XL. No. S.

\section{NOTES ON THE CRAYFISHES}

IN TIIE

UNITED STATES NATIONAL MUSEUM

AND THE

MUSEUM OF COMPARATIVE ZOÖLOGY

WITH DESCRIPTIONS OF NEW SPECIES AND SUBSPECIES

TO WHICII IS APPENDED

A CATALOGUE OF THE KNOWN SPECIES ANT SUBSPECIES.

BY

WALTER FAXON.

With Thirteen Plates.

CAMBRIDGE, U. S. A.:

Drinted for the Museum.

JULY, 1914. 

Demotrs of the Duseum of Comparative zoölogy

AT HARVARD COLLEGE.

VOL. XL. No. S.

\section{NO'TES ON 'THE CRAYFISHES}

IN THE

UNITED STATES NATIONAL MUSEUMI

AND THE

MUSEUM OF COMPARATIVE ZOÖLOGY

WITH DESCRIPTIONS OF NEW SPECIES AND SUBSPECIEN

TO WHICH IS APPENDED

A CATALOGUE OF THE KNOWN SPECIES AND SUBSPECIES.

BY

WALTER FAYON.

With Thirteen P'Lates.

CAMBRIDGE, U. S. A.:

printed for the Museum.

JuLY, 1914 . 

acherontis, Ortannicus

ecualnatus, Bartonius, bartoni1 $.66 ! n-424: 5-67$

8cut1ssias $=$ blendingil, acutus, Ortmann1cis $\ldots \ldots \ldots 17-413: 8 \mathrm{~F}-22$

acutus $=$ blandigig11 =8cutus, ${ }^{\circ}$ timannicus $\ldots \ldots \ldots \ldots 17-413:$ F -21

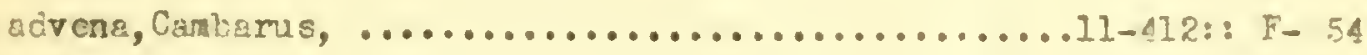

affinis, Faxonius ........................

alabaansi s, Faxonius ........................... 52-420: : F-104

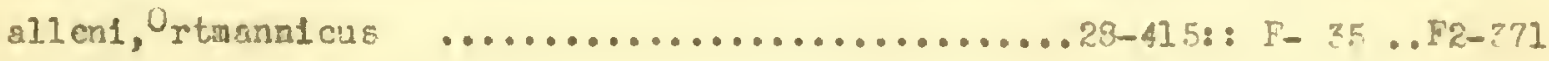

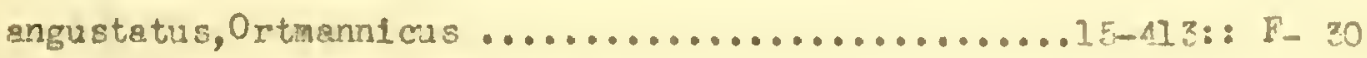

areolatus, Cambarellus, montezumae ..............22-416: :

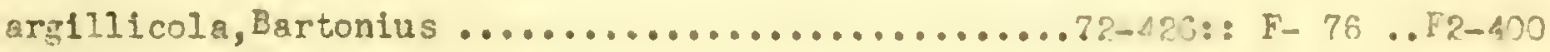

a sperimanus, Bartonius, bartoni1 .............66g-424

atkinsoni, Procanbaris ..................... -4.11

syersif, Bartonius .......................... $52-4,2$

aztecus $=$ mexicanus, Procanbams $\ldots \ldots \ldots \ldots \ldots \ldots 4-410:: \bar{F}-51$

Berbetus, Ortmannicus .....................25-414

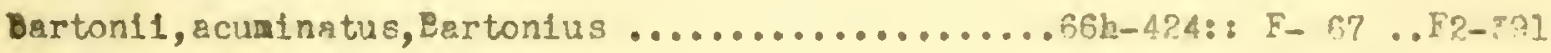

asperimanus, Bartonius ..............figg-424: : F2-?7I

Bartontus ........................6-423

carinlrostris, Dartonius ...........66n-423: F2-284

cavatus, Bartonius $\ldots \ldots \ldots \ldots \ldots \ldots \ldots$..........

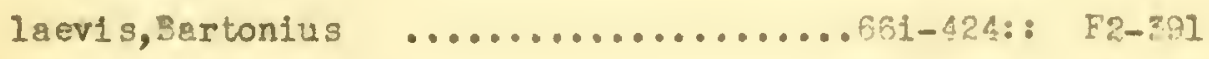

longirostris, Bartonius ............6. 6s-4?4: F-s4

longulus, Sartonfus ...............66e-424:: F-75 ..F2-88a

montanus, Partonfus...............68b-4?z: : F-6ศศ.. FR-798

robustus, Bartonius ...............63c-423: : F-61.. F2-?87

spinirostris, Dertonius $\ldots \ldots \ldots \ldots \ldots$........ $658-124$

tenebrosus, Bartonius ................6 6 j-424

veteranus, Bartonius ..............6sf-424: : F2-389 


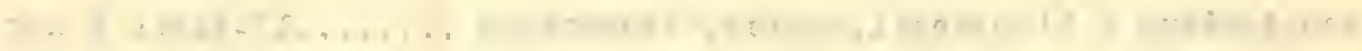

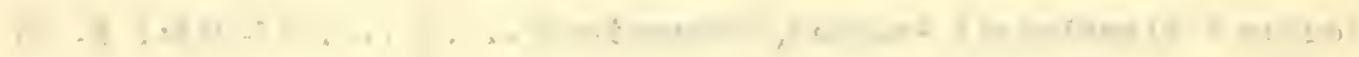

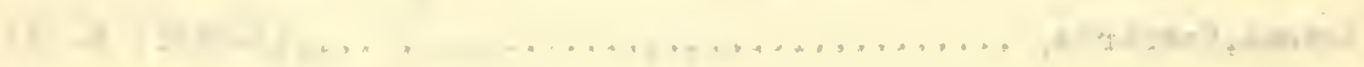

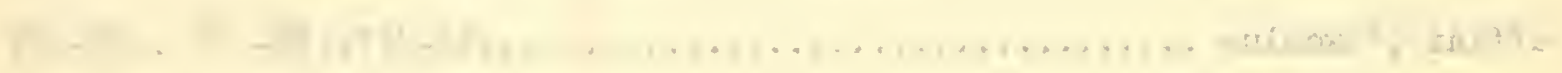

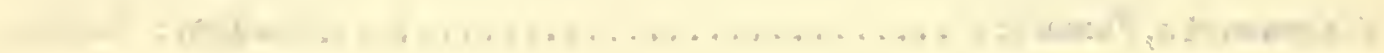

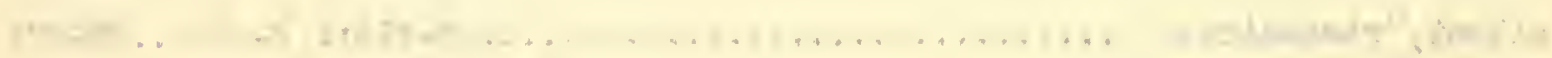

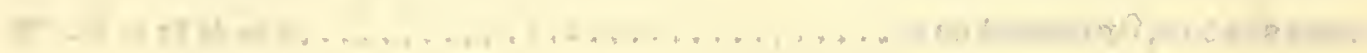

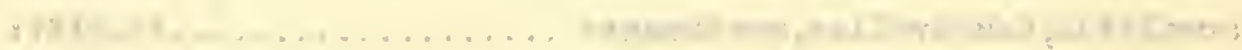

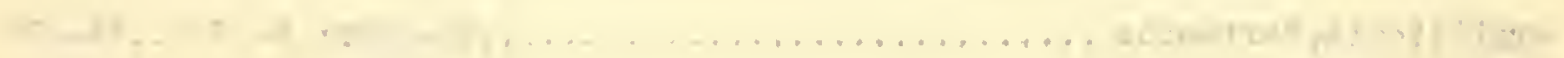

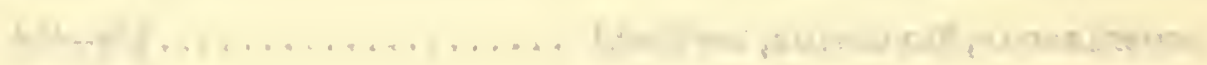

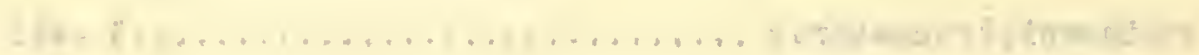
$1-1$

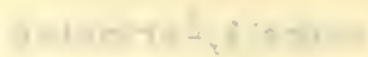

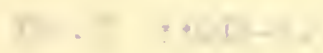

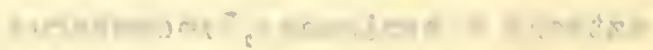

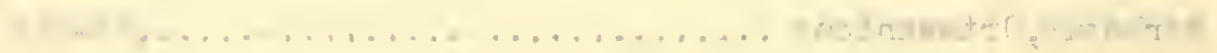
$+\ldots+\ldots \ldots \ldots \ldots$.

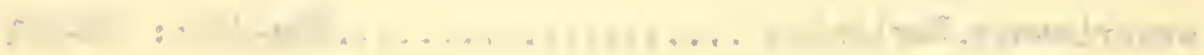

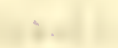

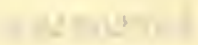

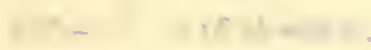

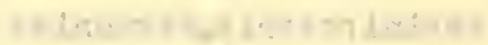
$+=$

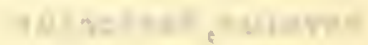

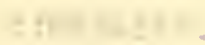

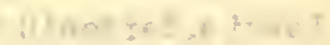

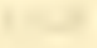
$.1 \ldots$

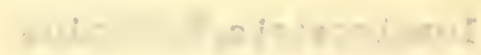
. . . * an -1.0

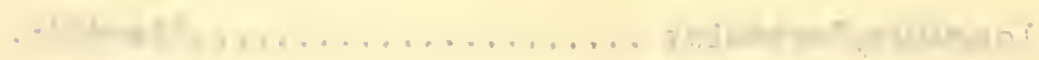

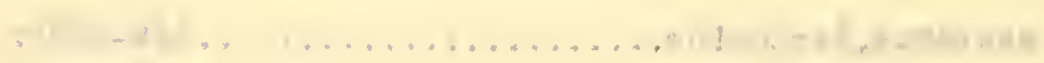
, t $1, n=$

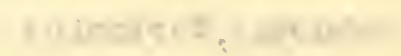

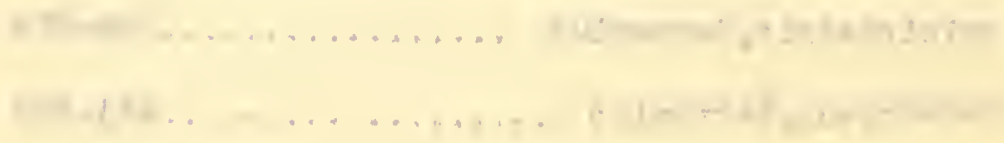


blending11, ecutus, ortmanni cus .................. 17-41z: F2-357

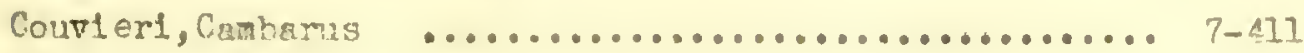

carinatis $=$ di grueti, Procarbams ................... 1-410

carlnirostris, Bartonius, bartoni1 ................ 66s-42?: $2-z ? 4$

carolinus, Dartonius ...........................70-425:F-54, F?-295

dublus, Bartonlus, ..................... 70a-425:F-70

monongelensts, Bartonius ................ 7nb-425

cavatus, Bartonius, bartonil ....................... $56 k-425$

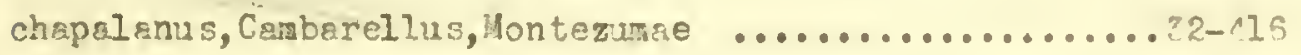

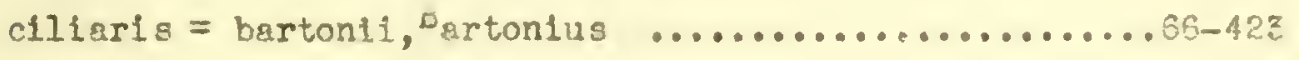

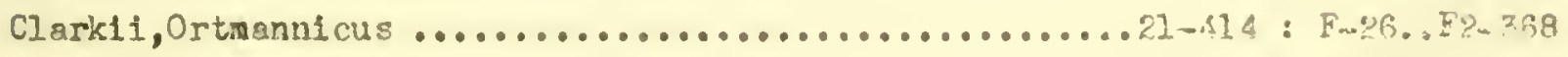

paeninsulanus,0rtannicus, ................2Ir-114: F2-369

Clypeatus, Faxonella ............................. 74-126: F2-470

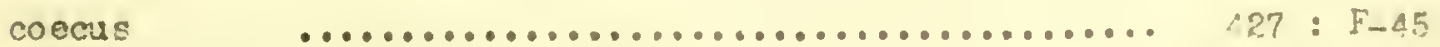

corpressus, Faxontus ........................47-419:F-105

consobrinus, Procambarus, cubensts .................

couesi, Faxonius ............................... 50-420 : F-97

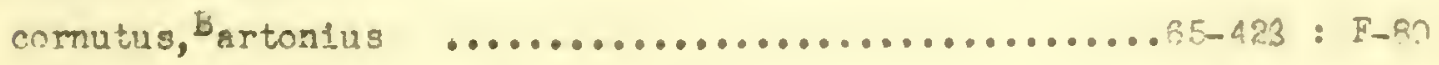

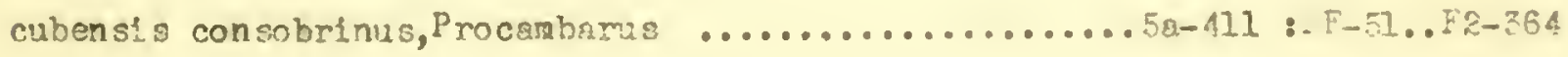

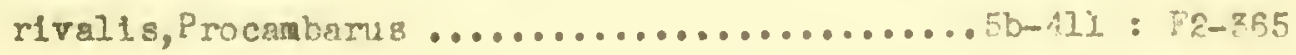

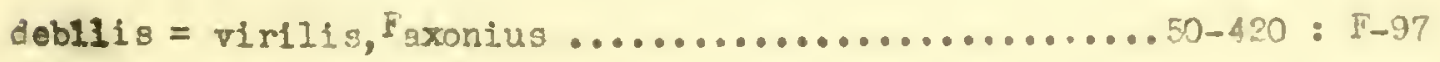

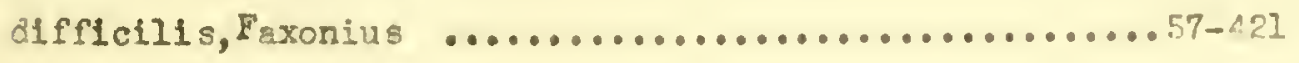

siguet1,Procambams .......................... 1-410: F2-z62

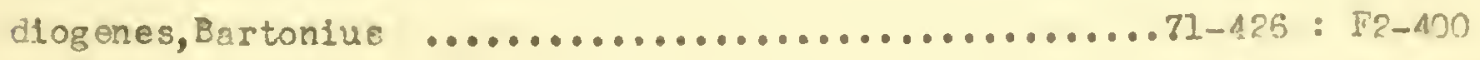

Iudovicianus, Bartonlus ,................71a-426:F-72..F2-400

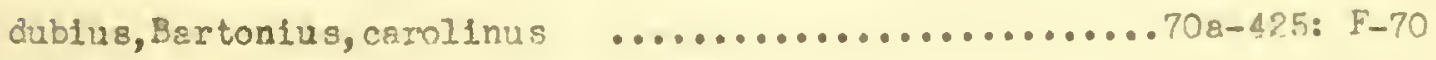

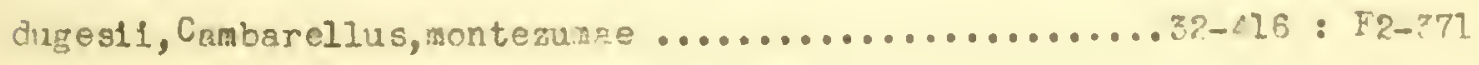


ans …

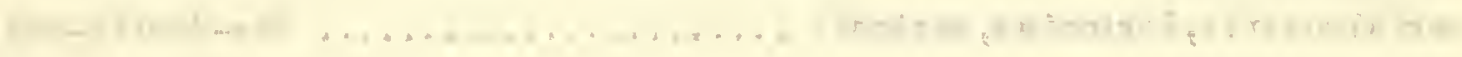

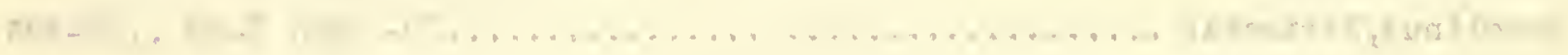

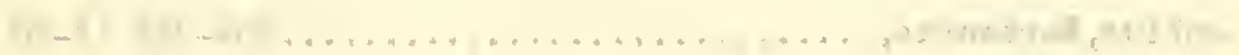

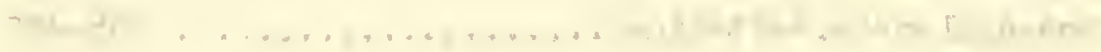

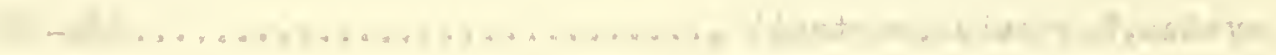

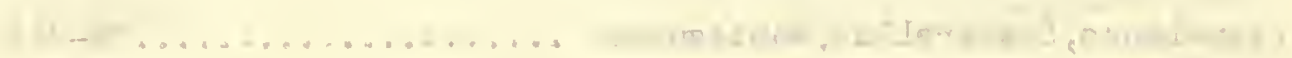

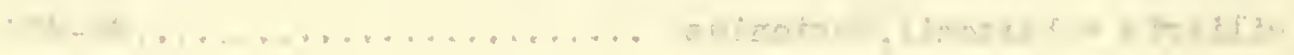
$0+2 \ldots+\cdots+1 h-$

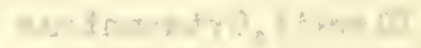

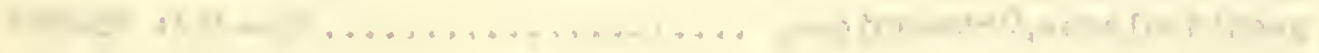

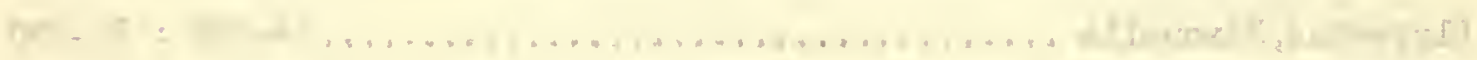

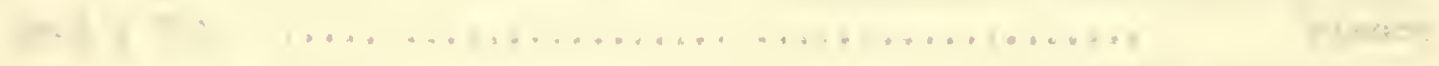

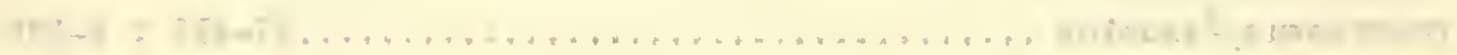

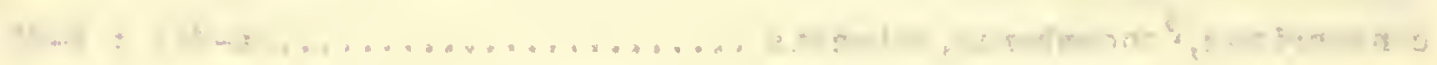

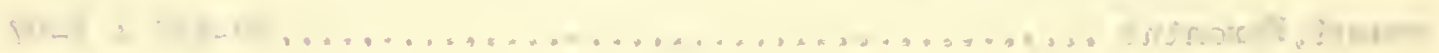

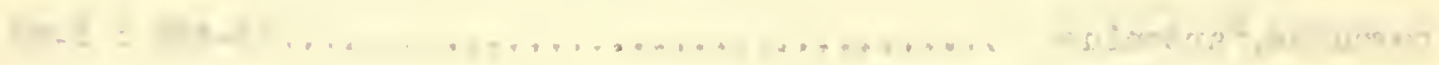

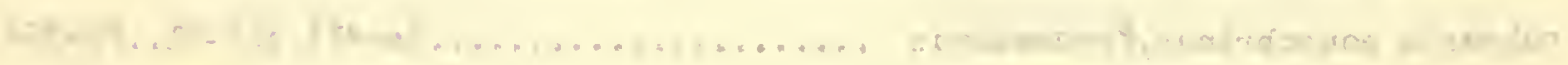

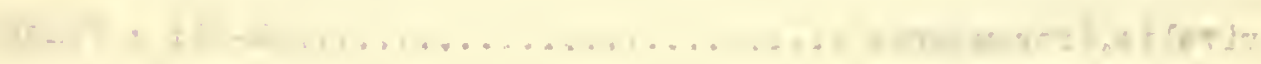

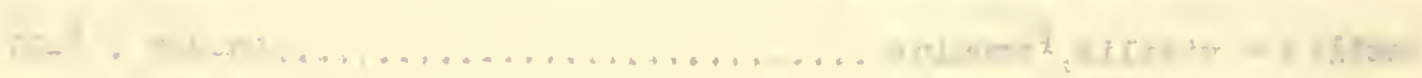

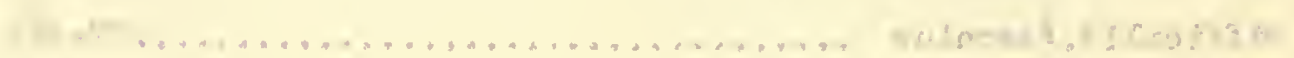

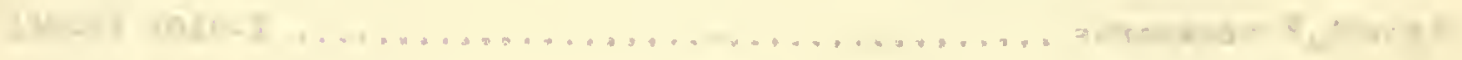

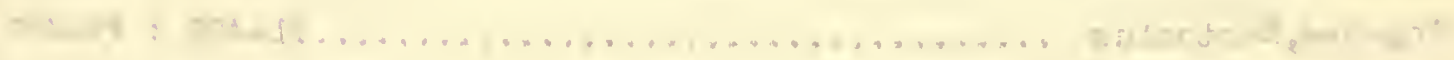

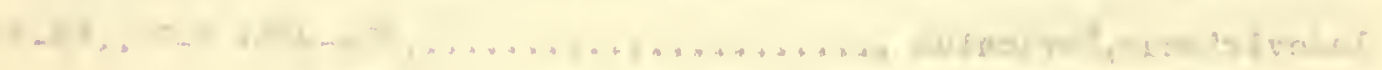

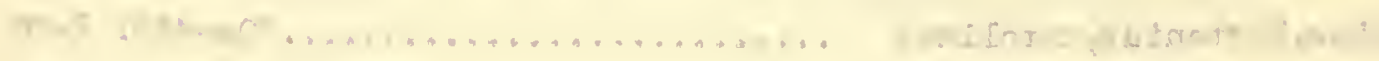

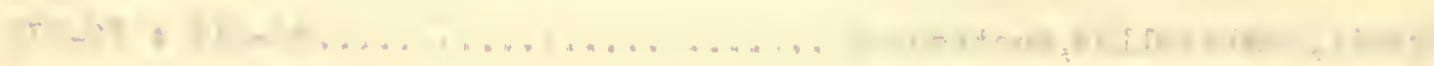


erlchsonianus, Faxinnus .................? ra- 48

eversanni, Ortannicus ......................23-414

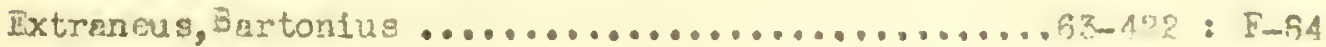

girardianus, Bartonlus ................-422: $F-79$

fallex, Ortasnnicus .......................... $41 z ; F-23 . . F 2-368$

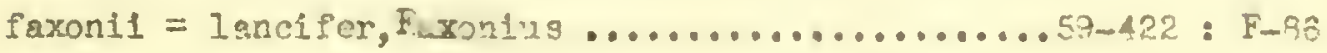

forceps, Faxonius .......................41-418 : F-1.19

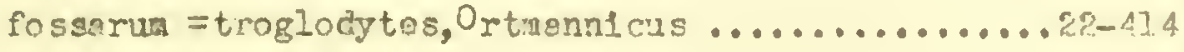

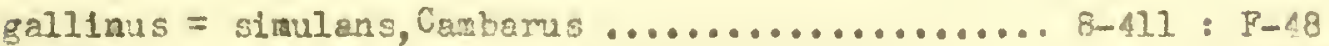

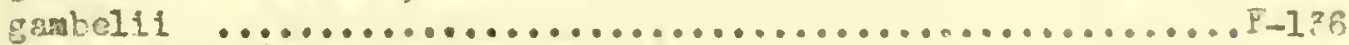

girerdianue, Bartonfus, extraneus .............6. ${ }^{T}-42 z: E-7 ?$

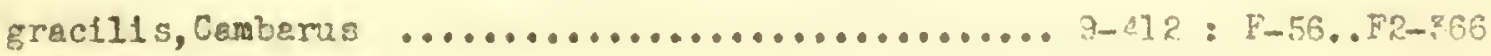

graysoni,Bartonius ......................

gritelmi, Faxonius, splrosuo ..............4?-419: F2-375

Fagen 1enus, Cambarus ...................10-412:F-56.F2-?56

hamulatus, Ertonius ....................60-422: F-81

herrisoni1, Faxonius ......................?

hagi, Ortaknicus,....................... 18-41?:F-?4..F?-?68

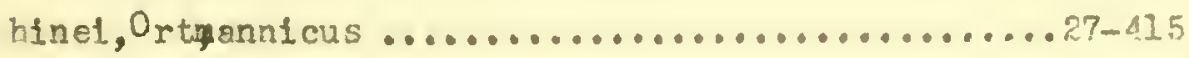

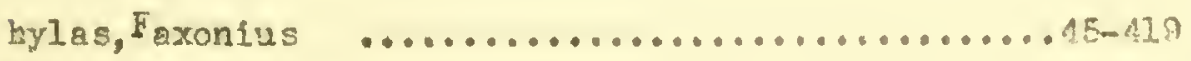

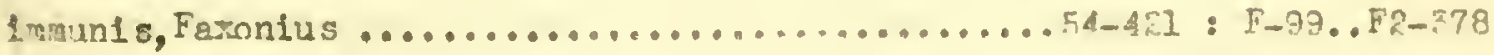

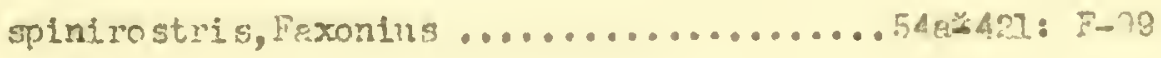

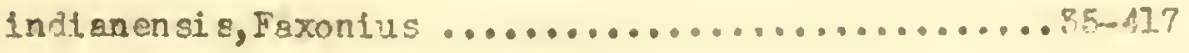

Inermis $*$ pelluctdus, 0 rtmanntmas .............28-115:F-12

fordant, Dartonius ........................... 423 : F-33

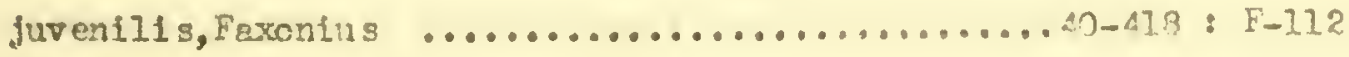

laevis, Bartonius, ba toni1 ................... fri-424

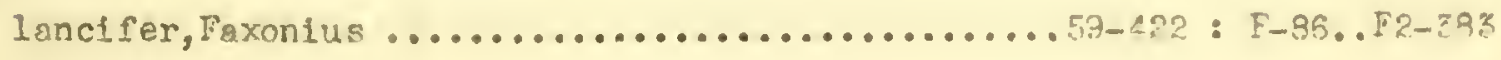

latimanur, Bartonius ......................37-405: F-6n.,F2-835 


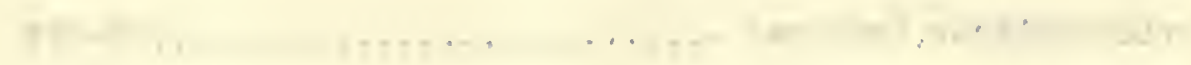

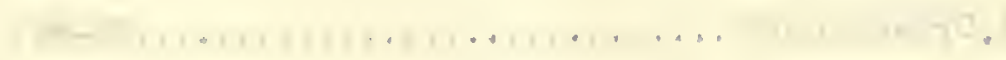

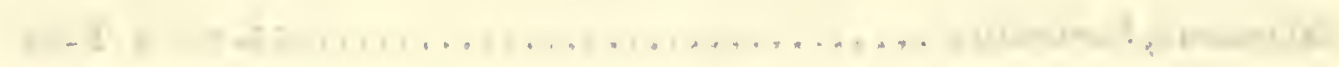

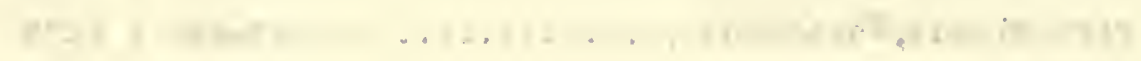

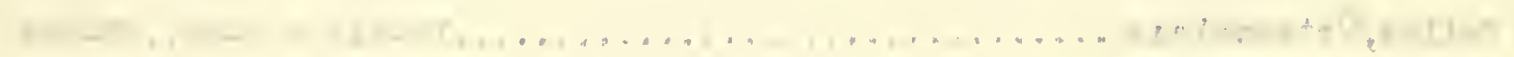

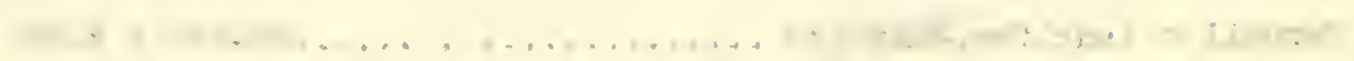

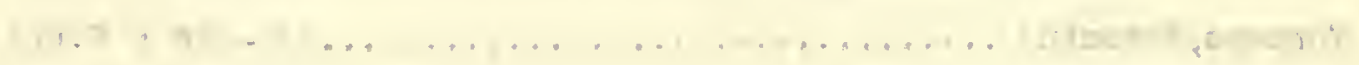

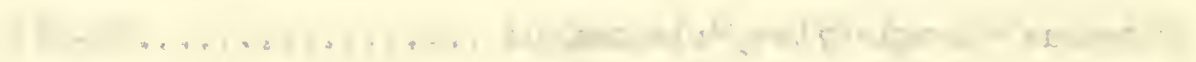

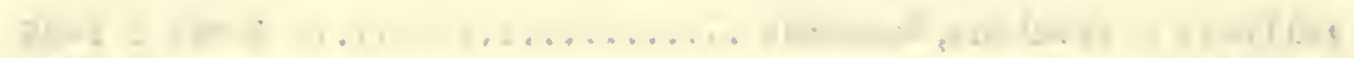

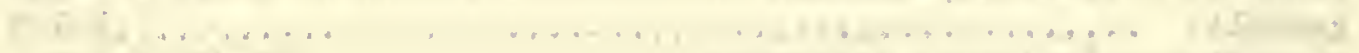

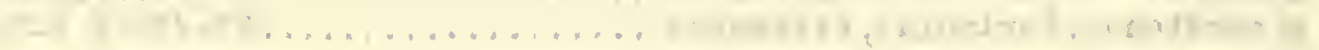

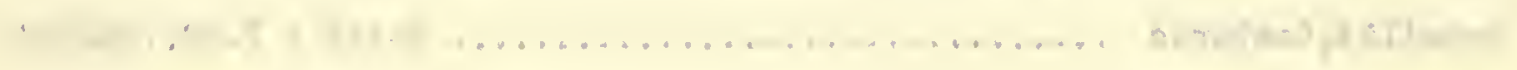

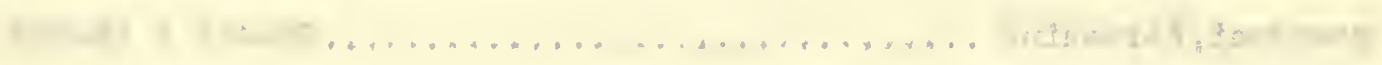

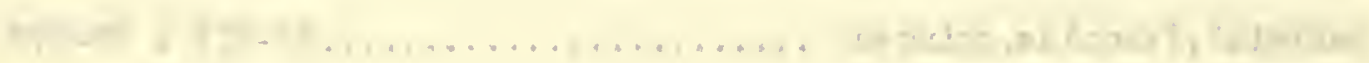

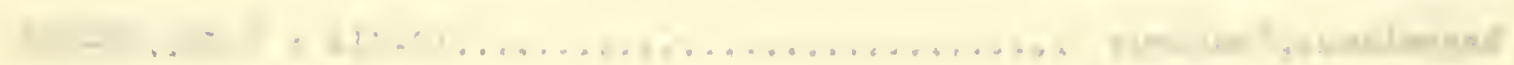

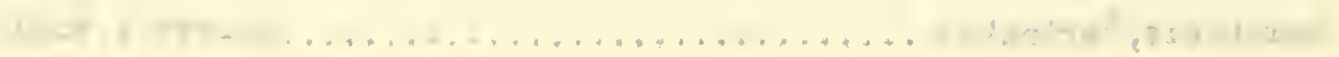

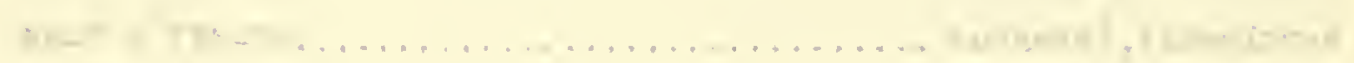

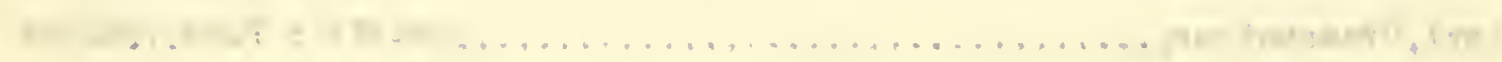

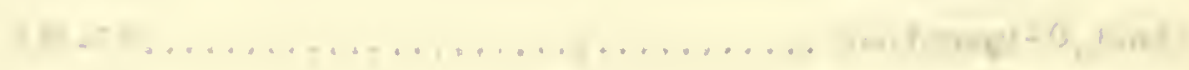

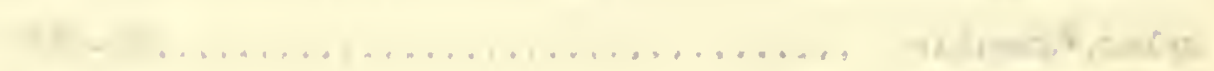

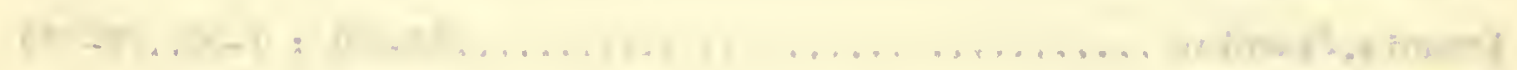

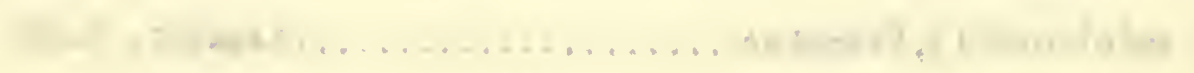

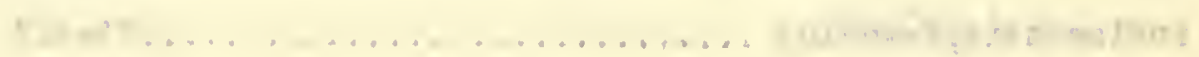

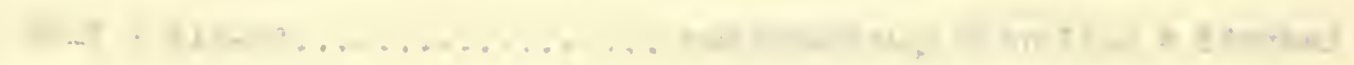

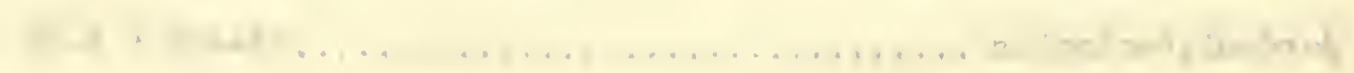

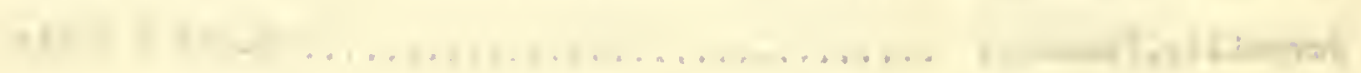

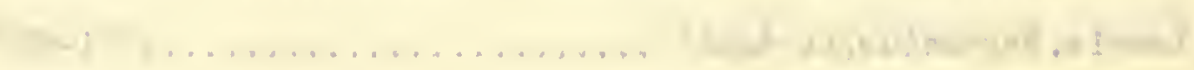

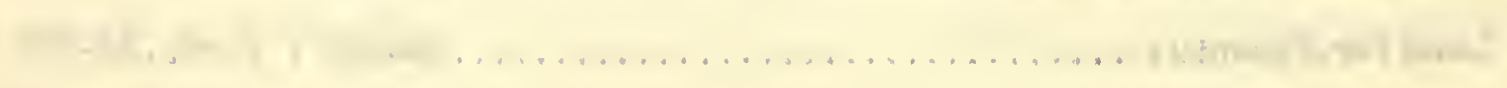

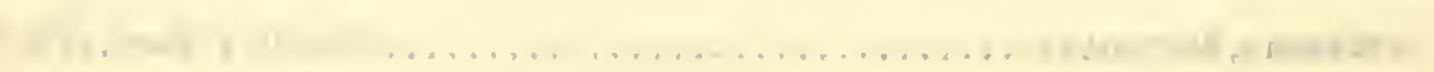




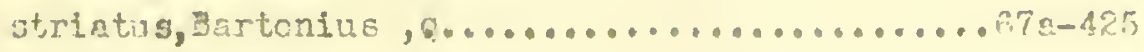

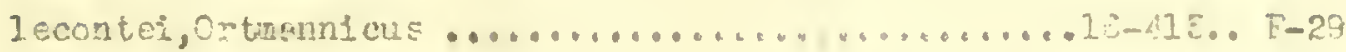

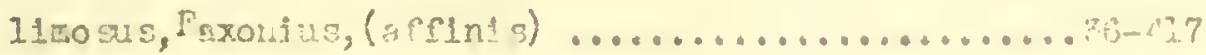

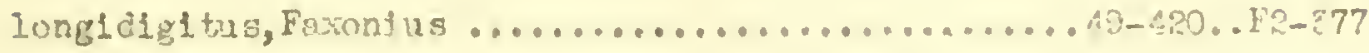

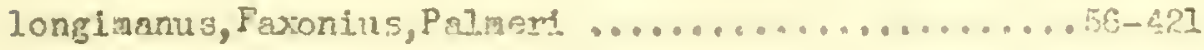

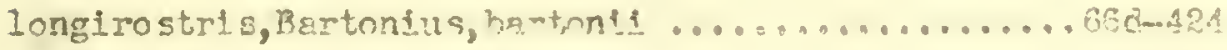

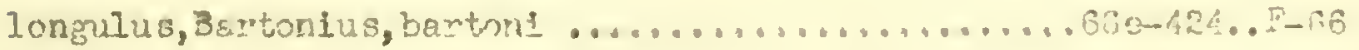

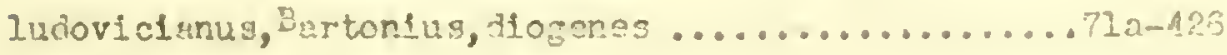

Menl culgtus, sp.? ..................... $427-F-23$

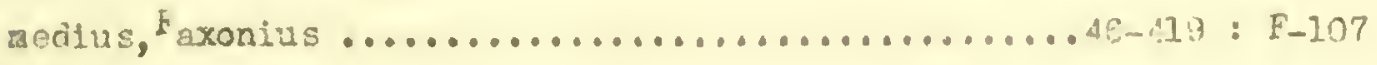

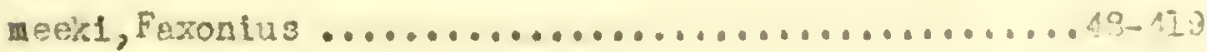

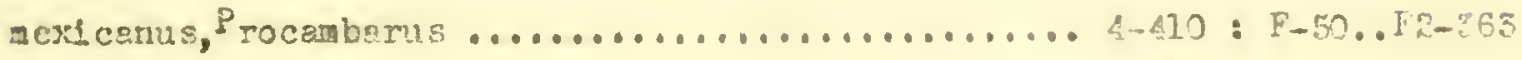

a1se1seippiensis, Faxonius ...................

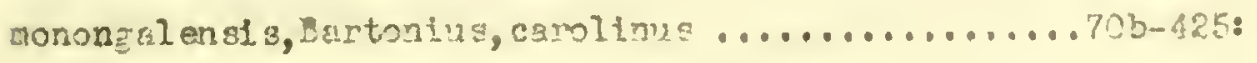

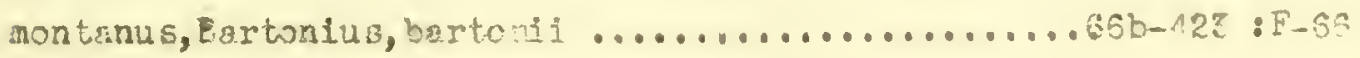

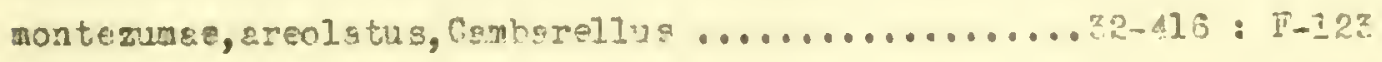

chaprinas, Cemberel1ug ............?2-415: $\$ 2-371$

duges11, Cerbare11uv ................2-416: $: 2-371$

occicistolie, Cerbgrellus .............22-416: F2-z71

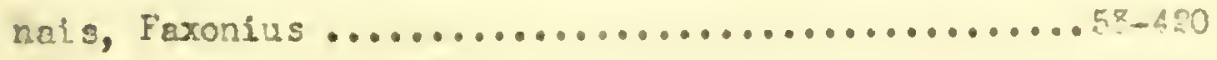

nebrascensis $=$ defene, Bartonius ..............71-426: $P-75$

neglectus, Faxonius ..........................118: F2-7.75

ohesia, Eertonius ........................71-A: : $F-71$

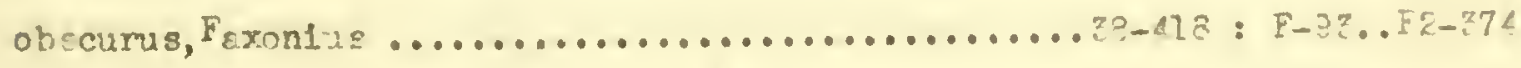

occldentslis, canharellus, monterusee .............. $2-416$

oreganus

F-1:3

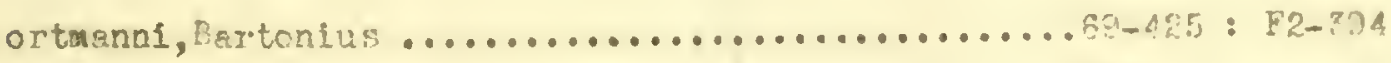

preninsulsus, Ortmenricie, clark11 ..............216-414

palsert. Fuxonius ..................................... : F-103

longianu, Faxonius ................56-421 
$+\cdots, \ldots, \ldots, \ldots, \ldots, \ldots+\ldots,+\infty, \ldots ;$

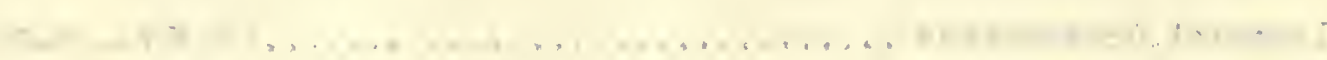

$\ldots \ldots \ldots \ldots \ldots \ldots \ldots+\ldots \ldots+1+\ldots+\ldots$

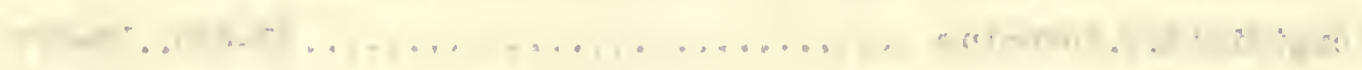

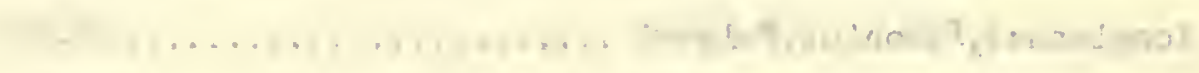

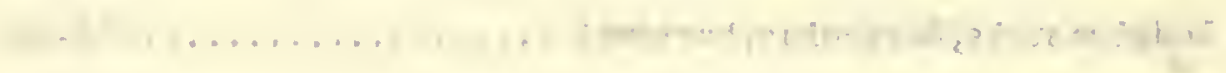

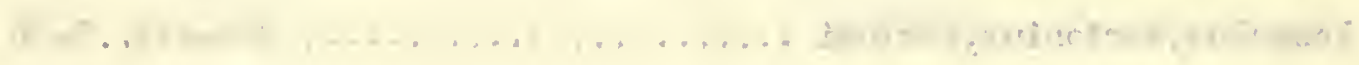

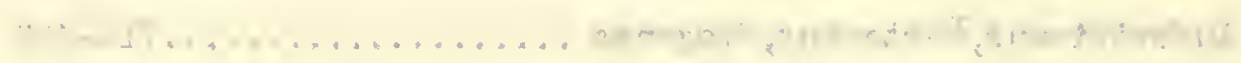

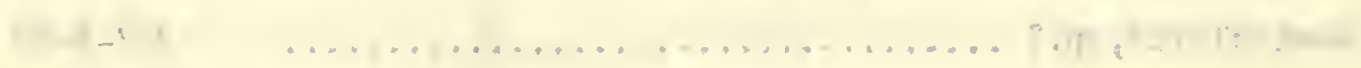

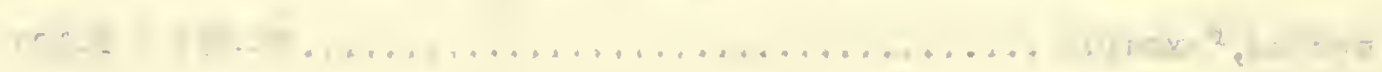

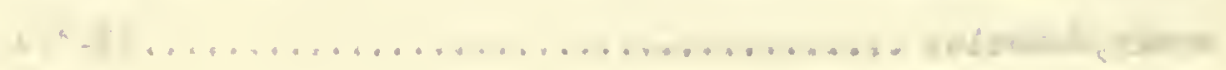

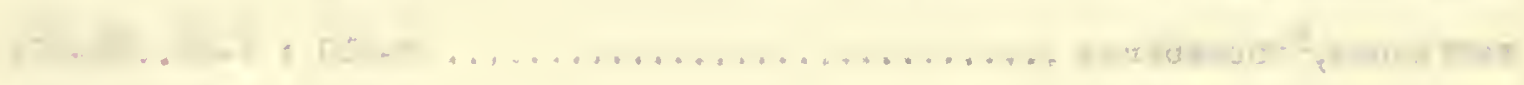

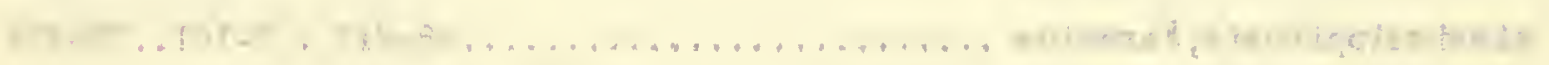

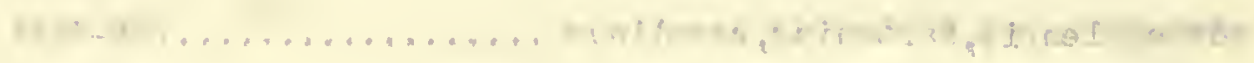

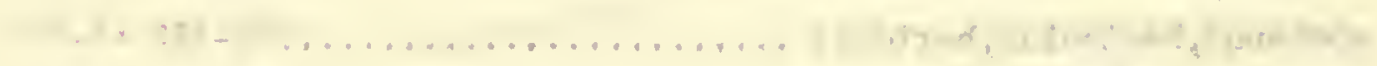

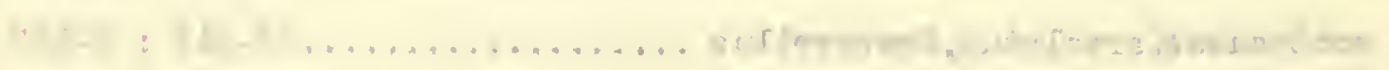

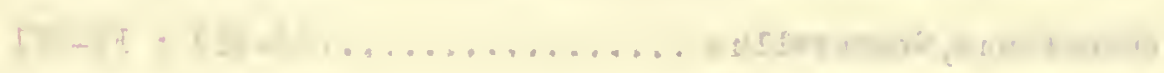

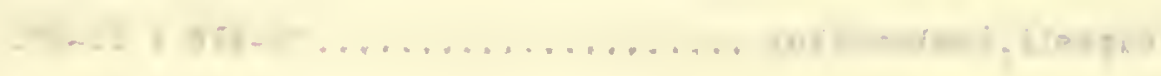

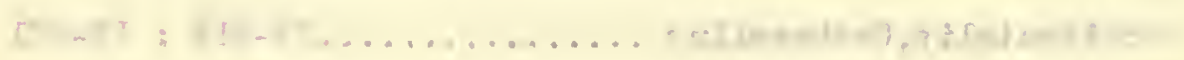

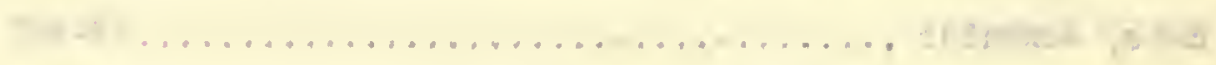

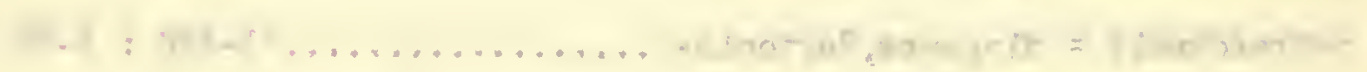

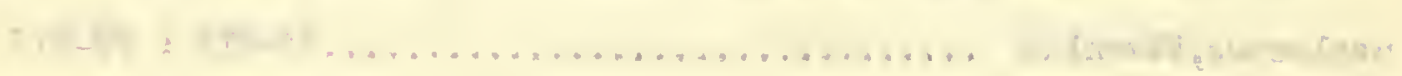

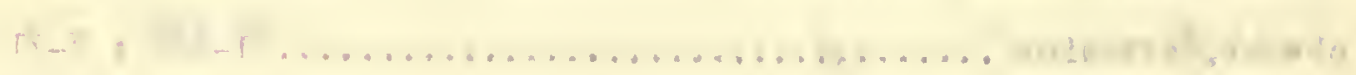

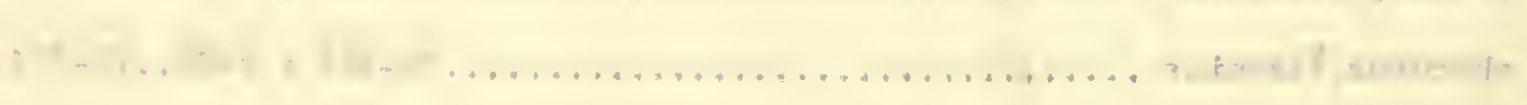

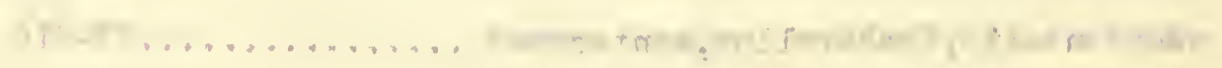

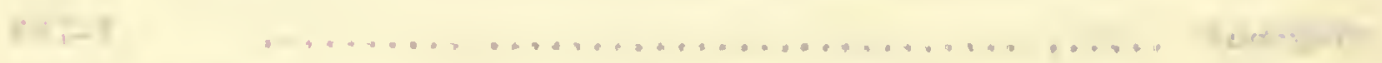

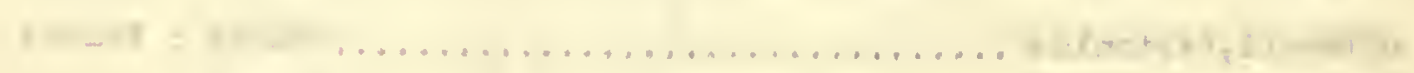

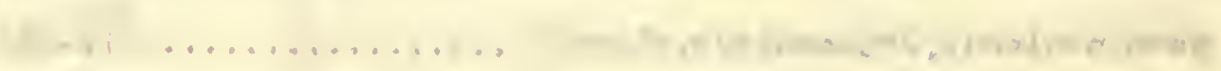

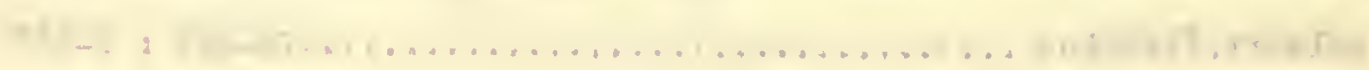


peradoxus,Paracambarus ......................?-415

pealed, Faxontus, affinis ...................... 36-417:F-88

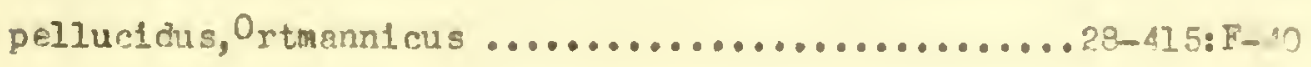

testil, Ortmannicus $\quad \ldots \ldots \ldots \ldots$..........29a-415

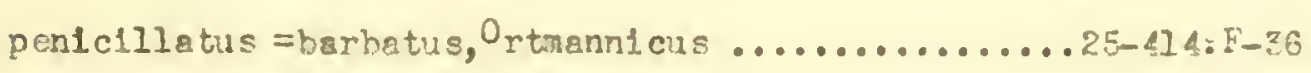

p1losiaenus, Procambarus ..........................10:F2-362

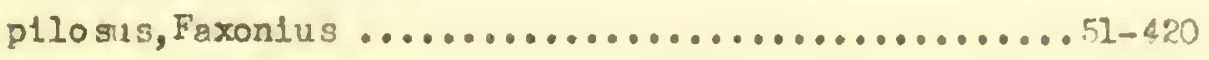

placicus, Faxontus .......................40-418: F-111

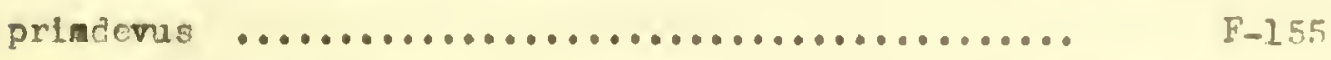

propinguus, Faxonius ........................4-417:F91..F2-37z

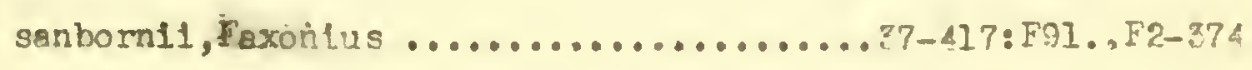

pubescens, ortannicus ........................... 412:F-zI

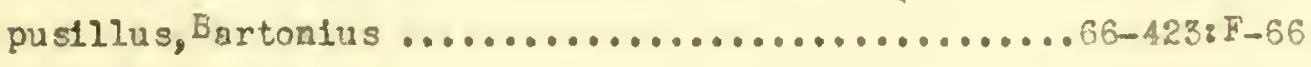

putnani, Faxontus .........................44-419:F-118..F2-377

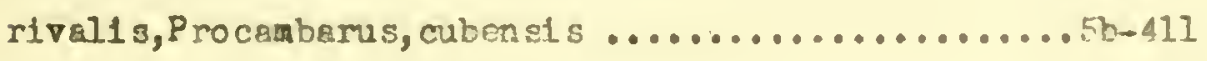

robustus, Bartonfus, bartonil ................. sfic-12z:F-67

rusticus, Frxonlus ......................40-418:F-108.. Fr-?75

sanbornl1, Faxonlus, proplnçus ............... $77-417: F-32$

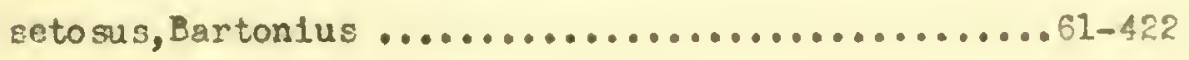

shufeldt11, Canbarellus .......................16:F-124..F?-z71

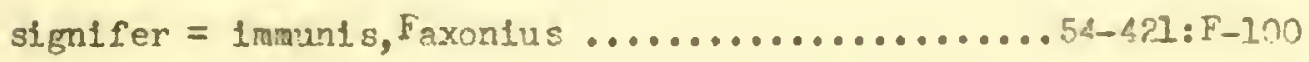

simulans, Cambarus ..................... 8 $411: F-48 . F 2-z 65$

sloant1, Faxontus .......................... $14-417: F^{\prime}-89 . . F 2-372$

splculifer, Ortmannicus .......................

sninirostris, Bartonius, bsrtont1 .............660 424

Faxontus, imaunis ................. b-4:1:F- 91

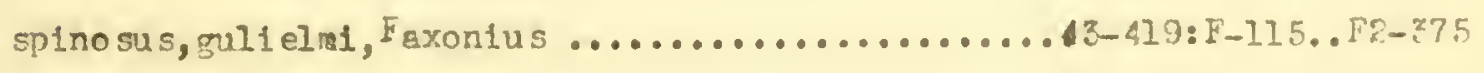

strlatus, Bertonlus, let1manus ..............678-425

styglus, sp. .......................... $\angle 27: F-46$ 


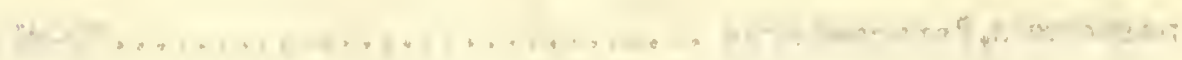

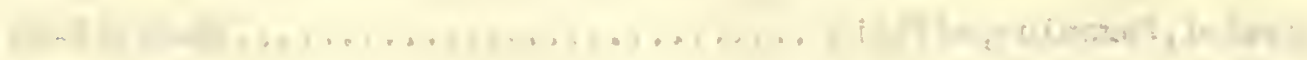

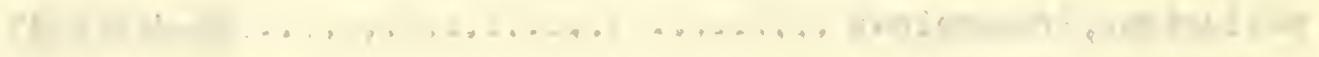

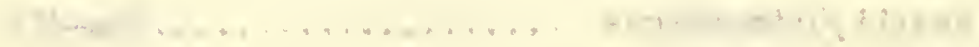

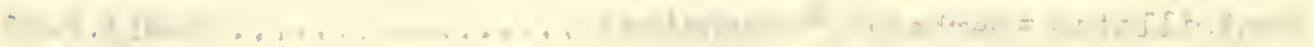

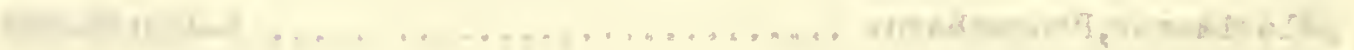

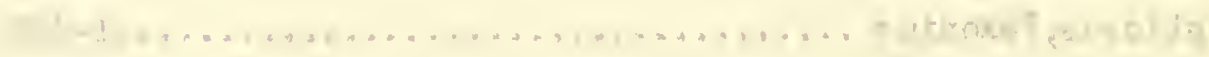

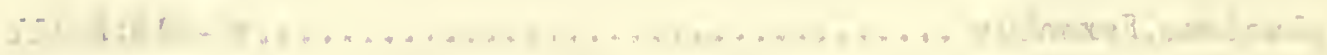

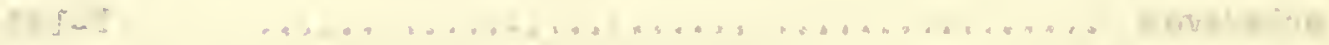

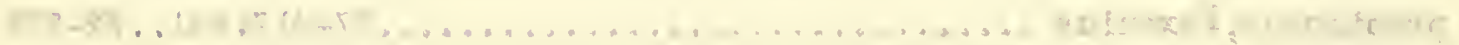

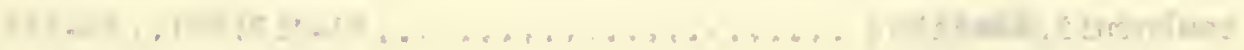

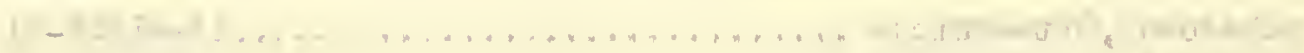

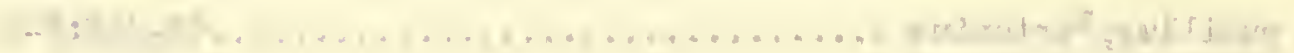

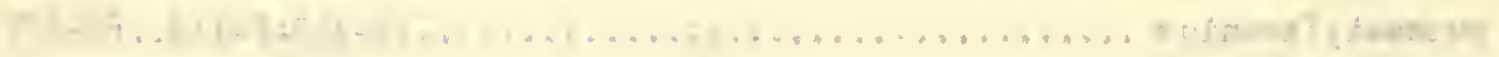

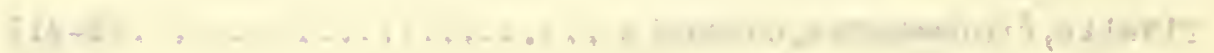

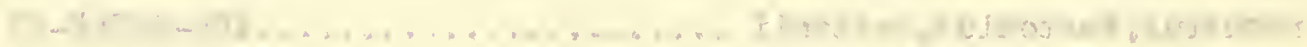

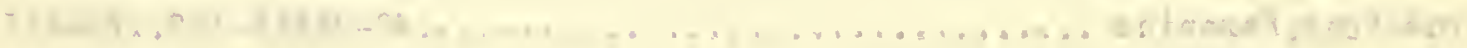

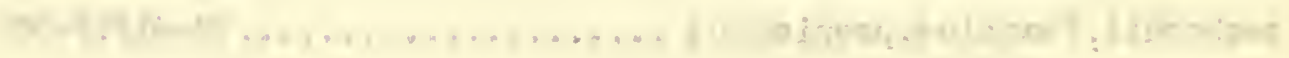

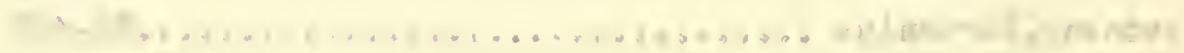

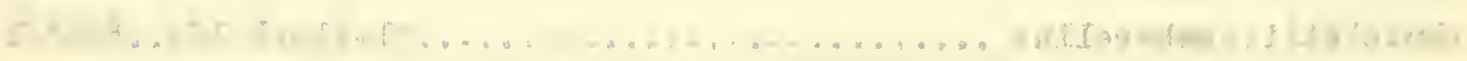

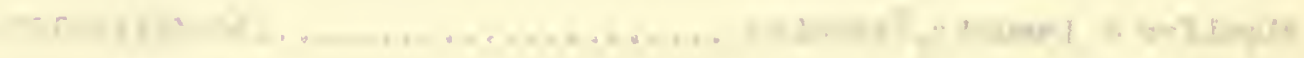

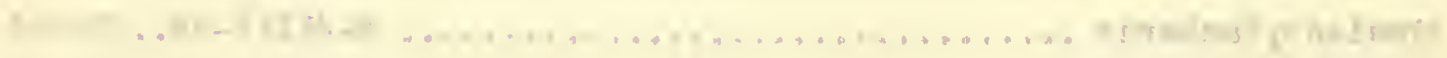

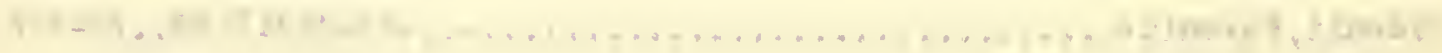

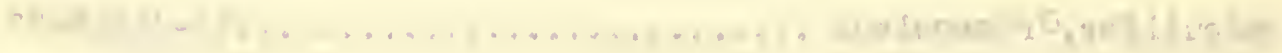

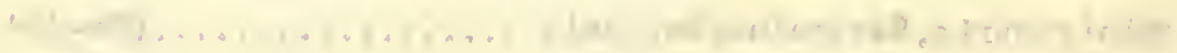

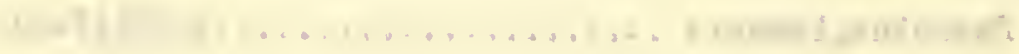

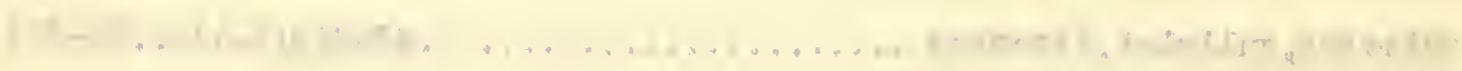

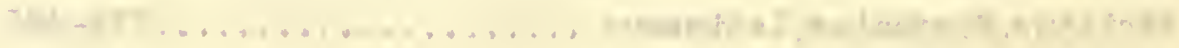


tenebrosus, Bartonius, bertonil $.66 j-424$

test11,Ortmannicus, pellucious - $29 a-415$

troglodytes, Ortmennicus $22-414: F-27$

typhlobius sp? $.427: F-45$

Ohleri, Bartonius $.73-423: F-77 . . F 2-400$

Yalldus, Farontus $.55-421: F 2-782$

veteranus, Bartonius, bartonil $.66 f-424 \ldots .72-283$

versutus, Ortmannicus $.12-412: 1-3 \cdot 4 \cdot . F 2-267$ vien-virids, Ortannicus $.24-414: F 2-370$ viricis, Fexonius $50-420$ virilis, Faxonius $50-420: F-95+12-277$

whitmant $=$ longidig1 tus, ${ }^{\text {axonius } \ldots . . . . . . . . . . . .49-420 ~}$ mi egmenn1, Ortaannicus ......................26-415:F-78. F2-369 ल111 amsoni, Procambrus $2-110$ $\rightarrow 1$ sconsinensis, Faxonius $40-418: F-113$ 


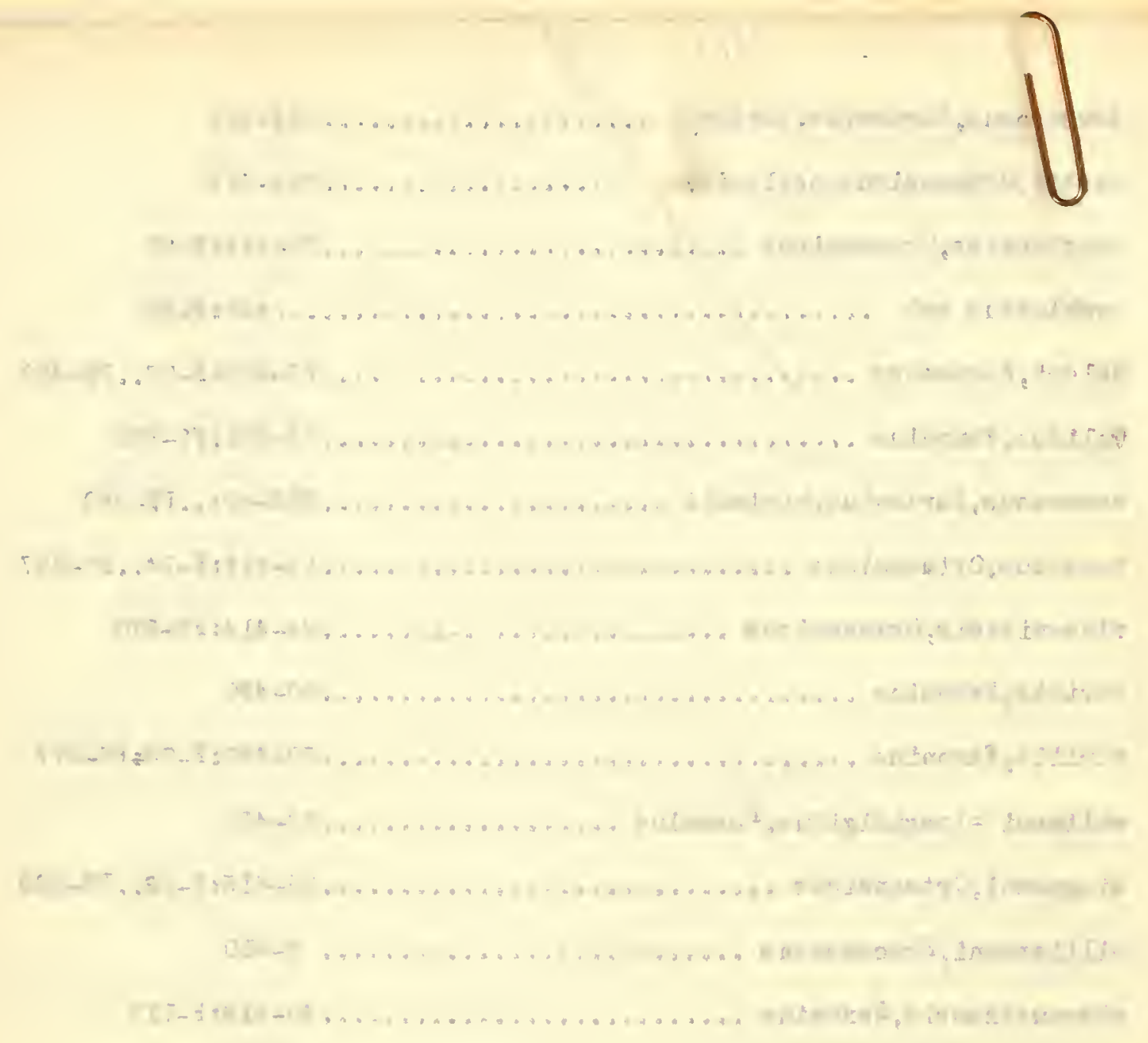




\section{PREFATORY NOTE.}

THE following notes on Crayfishes were made during an examination of all the Crayfishes that have been received at the United States National Museum and the Museum of Comparative Zoölogy since my last paper on these animals was published in the Proceedings of the United States National Museum, Feb. 7 , 1S9S, 20, p. 643-694, pl. 62-70. I am deeply indebted to the authorities of the National Museum for sending to me the vast amount of material that has come to Washington since my last review of the subject. I am also indebted to Mr. W. P. Hay of Washington, Prof. S. E. Meek of the Field Museum of Natural History, Chicago, Ill., and Dr. A. E. Ortmamn of the Carnegie Museum, Pittsburgh, Pa., for the loan of specimens. 


\section{NOTES ON THE CRAYFISHES. $\quad \checkmark$}

\section{Astacopsis australasiensis (Milne Edwards).}

Astacus australasicnsis M. EDw., Hist. Nat. Crustacés, 1837, 2, p. 332, 11. 24, f. 1-5.

There are two eotypes of this speeies in the Museum of Natural History in Paris. One of these, a female, has been kindly loaned to ne by Prof. E. L. Bouvier. The rostrum of this specinen is long-triangular, excarated, the aemmen provided with an upturned, blunt, apical denticle and a similar dentiele on each side; behind the lateral dentieles the margins of the rostrum are obscurely erenate. 'The post-orbital ridges teminate anteriorly in a blunt tubercle; they are chamnelled throughout their length and ar' followed by two obsoleseent tubereles at a little lower level on the gastric region; the hepatic area also is tuberculated and a few less prominent tubereles are visible on the posterior margin of the cervical groove on each side of the earapace. The areola is broad, narrowing from before backward, punctate. Pranchial regions obsoletely squamose. Abdomen rather smooth, with a submarginal row of small tubercles on the pleura of the second somite; plemra rounded. Apine on dorsal face of inner branch of posterior abdominal appendages submarginal. Antennal seale of moderate width, flanked with a sharp denticle on the outer side at the base. Anterior process of the epistome triangular, with eonvex sides, ending anteriorly in an attenuated angle. Chelipeds nearly symmetrieal, meros armed below with spines biserially disposed, upper margin thereof atso furnished with a few (three or four) spinules; upper margin of earpus armed with two proninent spines, the distal the larger; outer faee furrowed longitudinally, slightly tubereulate along the upper edge of the furrow; innel face of the carpus somewhat tubereulate and armed with one spine in the middle of the distal border. Propodite distinctly earinate on the upper border, less distinctly so on its lower border; the superior crest is eut into five teeth, the lower margin is denticulate; the outer face of the propodite is thickly eovered with deprensed tubercles. Daetylus furnished with one denticle near the proximal end of the upper border. Length, $63 \mathrm{~mm}$; length of earapace, $30.5 \mathrm{~mm}$; ; breadth of carapace, $13 \mathrm{~mm}$.; length of areola, $9 \mathrm{~mm}$; breadth of areola at anterior end, $6 \mathrm{~mm}$, at posterior end, 4.5 mm.; length of chela, $20 \mathrm{~mm}$.; breadth of chela, $10 \mathrm{nmm}$; length of dactylus, $11.5 \mathrm{~mm}$.

Bay of Sydney, Verreaux, No. 944, 1837. 
I doubt if this is the specimen figured by Milne Edwards: he gives as the length of the body, two inches; the figure, which is said to be life size, is $56 \mathrm{~mm}$. long.

Dr. Giuseppe Nobili ${ }^{1}$ also has examined the same cotype belonging to the Paris Museum and is convinced that it belongs to the same species as a male speeimen, 66 mm. long, in the Museum of Natural History of Genoa, said to have been collected by D'Albertis in 1872 on the little island of Sorong in the Strait of Galevo, northwestern coast of New Guinea. Perhaps a misplacement of labels has oecurred in this ease; the extraordinary distribution of this speeies implied by the nominal locality label accompanying the Genoa specimen, as well as the nature of the islet of sorong, make it probable that the specinen was in reality secured at sydney, Australia, where D'Albertis eollected in 1873.

Astacopsis australasionsis may turn out to be nothing but an immature stage of A. spinifera.

\section{AstaCONEPhrops albertisil Nobili.}

Astaconephrops albertisii NobIL, Annali Mus. Civ. Storia Nat. Genova, 1499, 40, p. 244; Bolletino dei Musei di Zoologia ed Anatomia Comparata di Torino, June 9, 1903, 18, p. 1.

The genus Istaconephrops, with its one species albertisii, based on a single female specimen in the Museum of Genoa which is said to have come from Katau on the southern coast of New Cruinea, needs further elucidation. According to Tobili the margins of the rostrum (which in a general way resembles the rostrum of Paranephrops) are continued back, in the shape of two keels, over the earapace to the cerrical groore; the abdominal segments are produced into points laterally; the inner branch of the last pair of abdominal appendages is furnished with a rib or keel on the dorsal face, terminating in a spine near the centre of the branch: the chelae are long and slender and on account of the elevation of the middle of the two faces appear subprismatical; the carpus is eylindrical, or rather depressed, and armed on the inner side with a sharp spine concealed in a large tuft of hairs; the imner margin of the palm is furnished with minute teeth, all the rest of the palm being smooth; the fingers are unarmed, but provided with hairs along their eutting edges.

From the description of this aninal given by Nobili one would infer a conıbination of the characters of Nephrops, Paranephrops and Cheraps. The

${ }^{1}$ Contribuzioni alla Conoscenza della Fauna Careinologica della Papuasia, delle Molluche e dell' Australia. Annali del Mus. Civ. Storia Nat. Genova, 1599, 40, p. 246. 
branchial formula is the same as in the genus Cheraps, and essentially the same as in Paranephrops; but aceording to Nobili the podobranchiae of the eighth and ninth somites are not furnished with an ala or lamina in the genus Istaconephrops, whereas in the genus Cheraps these podobranchiae are alate.

\section{Parastacus araucanius, sp. nov.}

Plate 4.

Male:-Cephalothorax shorter than the abdomen, strongly compressed laterally, mostly smooth, minutely granulated on the sides; areola broad (about two thirds as broad as long), minutely punctated; rostrum short, not reaching the distal end of the second antennulary segment, margins elevated, slightly convergent from base to near the tip, where they abruptly converge to form the abbreviated acumen; the infero-lateral edges of the rostrum are visible from above, forming the superior borler of the orbit separated from the supero-lateral edge of the rostrum by a groove; distal half of the rostrum concare above; antero-lateral margins of the carapace produced into a prominent, rounded angle below the small eye which lies in a deep and uneommonly complete orbit. Post-orbital ridges, obsolete. The pleural angles of the abdomen are rounded, the telson long with a pair of lateral spines and a longitudinal median furrow on - its upper face along its distal half; the median rib on the upper side of the inner branch of the last pair of abdominal appendages ends in a small spine situate a little distance from the margin. Antennal seale short and broad. The chelipeds are asymmetrical, the right one being the larger; the meros is tuberculated on its lower face, granulate on the superior margin, but destitute of spines; the surface of the carpus is lightly squamoso-granulate, the granulations becoming more pronounced on the supero-interior edge where they take the form of blunt tubercles; the chela, too, is lightly squamoso-granulate, without any prominent spine or tuberele, except one blunt tubercle or tooth near the base of the immovable finger; the superior and inferior borders are rounded.

Dimensions. Length, $42 \mathrm{~mm}$; length of eephalothorax, $19 \mathrm{~mm}$; length of areola, $6 \mathrm{~mm}$., breadth of areola, $4 \mathrm{~mm}$.; length of larger elaw, $15.5 \mathrm{~mm}$., breadth of do., $7 \mathrm{~mm}$., length of dactylus, $8.5 \mathrm{~mm}$.

Corral, Chile, Dec. 1S, 1908, in a cascade stream. 'Thomas Barbour coll., M. C. Z., No. 7,355 .

This species is related to $P$. nicoleti (Phit.) and $P$. hassleri Fax. Like these it. has a strongly compressed cephalothorax, indicating a burrow-dwelling species. 
It differs from both of these species in its short and hroad arcola. Compared with $P$. nicoleti, it differs in the lack of sculpture of the chela and carpus. Compared with $P$. hasslcri, the rostrum is shorter, broader, and more abruptly truncate, the chela is rounded above and below and unprovided with the crest-like series of low, squamous tubercles.

Six species of Parastacus have been previously described from Chile, viz.:$P$. chilensis ( $\mathrm{II}$. Edw.) in 1837, P. spinifrons (Philippi) in 1882, P. nicoleti (Philippi) in 1882, P. bimaculatus (Philippi) in 1894, P. agassizii Fax. in 1898, and $P$. hassleri Fax. in 1S9S. The type of $P$. chilensis, a single dry specimen, is in the Muscum d'Tistoire Naturelle in Paris, and should be more fully described, since Milne Edwards's diagnosis (Hist. Nat. Crust., 1837, 2, p. 333) is entirely insufficient. In 1849 (Gay's Hist. Chile, Zool., 3, p. 211, Atlas, 2, Crust. pl. 1, f. 4) Nicolet described and figured as Astacus chilensis M. Edw. a crayfish certainly different from Milne Edwards's species, and R. A. Philippi therefore gave Nicolet's species a new name, Astacus nicoleti, in a paper published in the Anales de la Universidad de Chile, 18S2, 61. In a paper published in 1998 when I was ignorant of Philippi's paper, I also gave a name to Nicolet's crayfish, fortunately the same name that had been already given it by Philippi. In the same paper Philippi describes and figures a new species, Astacus spinifrons; the diagnosis is as follows:- A. rostro elongato-triangulari ad basin utrinque spinula acuta; earpo extus profunde sulcato, margine superiore grosse tuberculato; mano crassa subtus rotundata; digitis haud lineato-sulcatis, intus basi longe barbato-ciliatis.

In 1894 Philippi ' published a description of another new species of Parastaeus from Chile under the name of Astacus bimaculatus. This is probably the species which I described later by the name of Parastacus agassizii (Proc. U. S. Nat. Mus., 1898, 20, p. 690).

\section{Parastacus spinifrons (Philippi).}

Plate 9, Fig. 1.

Astncus spinifrons P'HLLPpI, Anales Univers. Chile, 1882, 61.

A male Parastacus in the Musem of Natural History, Paris, sent to me for identification by Prof. E. L. Bouvier, I think belongs to this species. It differ's,

${ }^{1}$ Dos Palabras sobre la Sinoninia de los Crustícens, Decápodos, Braquiuros o Jaivas de Chile. Anales Universidad Chile, 1894, 87, p. 369-379. I have been unable to consult either of Philippi's memoirs directly. Mliss Rathbun, lowever, has kindly furnished me with a transeript of the earlier one, copied from the volume of the Anales in the Lihrary of Congress, Washington, and Dr. A. E. Ortmann has courteously lent me a MS. copy of the later pitper, given to him by F. Philippi, son of the author. about 1900 . 
it is true, from Philippi's figures of $P$. spinifrons, at least from the copy of those figures in Dr. Ortmann's possession, in some respects, for instance the rostrum is shorter and broader and the immobile finger of the large claw is much longer. These discrepancies may be due to the inaceuracy of the original figures or of the copy of these figures which is all that I have before me. Philippi's diagnosis, moreover, takes no account of the pronounced asymmetry of the chelipeds, a marked feature of the specimen from the Paris Museum. I append a description of the latter; future explorations in Chile will determine whether it is the same species as Philippi's.

Cephalothorax subcylindrical, smooth, shorter than the abdomen; areola broad, considerably less than one half the length of the anterior section of the carapace; rostrum triangular, reaching to the distal end of the second antennulary segment, upper surface plane, with slightly elevated margins; post-orbital ridges obseurely marked exeept anteriorly where they form an elongate, low, tuberele without an acute spine; the antero-lateral angle of the earapace is produced to a prominent blunt angle below the orbit; there is no lateral or branchiostegian spine. The abdominal pleura are broad, with rounded angles. The antennal scales are broad, broadest in the middle; lower surface of the peduncle of the antenna hairy; epistoma triangular, anterior angle acute; third pair of maxillipeds clothed with dense hair below. Chelipeds unsymmetrical, the right one being much the larger, meros pretty smooth, except on its lower face which is provided with a row of small marginal tubereles and clothed with a heary coat of hair; the superior margin of the meros is clestitute of a spine; the carpus has a deep longitudinal groove along its external face; below this groove the surface is smooth, above it there are small squamous tubercles which on the superior border of the carpus assume the form of prominent tubercles, or blunt teeth, four or five in number; the infero-interior face of the carpus of the larger cheliped is likewise furnished with similar tubercles; the right (larger) claw is rery thick, with rounded superior and inferior border's; the body of the claw is beset with flattened low tubereles which are most pronounced anteriorly, near the socket of the dactylopodite; the fingers gape, are pitted in place of being tuberculated, and there are about three blunt teeth on the eutting edge of each finger, one of which is especially prominent; both fingers are hearily bearded at the base, especially on the inner side; the left (smaller) claw is nearly smooth, with long and slender finger's that meet throughout their length, destitute of teeth but furnished with a beard at the base, like the larger claw. Inner branch of the last pair of abdominal appendages armed with a submarginal spinule at 
the distal end of the median rib. Length, $90 \mathrm{~mm}$., length of earapace, $41 \mathrm{~mm}$., width of carapace, $20 \mathrm{~mm}$, width of base of rostrum, $6.5 \mathrm{~mm}$., length of rostrum, $9 \mathrm{~mm}$., length of arcola, $11.5 \mathrm{~mm}$., breadth of areola, $7 \mathrm{~mm}$., length of antennal scale, $7 \mathrm{~mm}$., greatest brealth of do., $4 \mathrm{~mm}$., length of larger elaw, $31 \mathrm{~mm}$, breadth of do., $17.5 \mathrm{~mm}$., length of superior margin of hand, $10 \mathrm{~mm}$., length of dactylus, $19 \mathrm{~mm}$., length of smaller chela, $23 \mathrm{~mm}$, breadth of do., $9 \mathrm{~mm}$., length of dactylus, $16 \mathrm{~mm}$.

There are four specimens of this species in the U. S. National Museum from the rivulets of MII. Bbok and Jones, Lake Nahuel Huapi, on the eastern slope of the Cordilleras in Argentina. The chelipeds are preserved in three of these specimens; in two the larger claw is on the left side, in one it is the right, as in the Paris specimen.

The tip of the rostrum is setose in this spccies, and in most cases there are a pair of minute, homy, bcad-like lateral teeth just back of the point of the rostrum. The rostrum is therefore essentially like that of $P$. bimaculatus. From the latter the present species differs in having much stouter, shorter-fingered, more heavily tuberculated claws, and a somewhat longer metathorax and narrower" areola.

Parastacus agassizii (= bimaculatus) has been recorded from Lake Nahuel Huapi by Ortmann (Proe. Amer. Philos. Soc., 41, p. 293). The specimens should be examined anew with reference to the possibility of their belonging to the present species, $P$. spinifrons?

Specimens from Puerto Montt, Lake Llanquihué, on the opposite slope of the Cordilleras, in Chile, are said by Doflein (Sitzungsber. Akad. Wissensch. München, 1900,30, p. 133) to agree wholly with my description of $P$. agassizii ' (= bimaculatus).

\section{Parastacus bimaculatus (Philippi).}

1stacus bimaculatus R. 1. PHinppi, Anules Universidad Chile, 1894, 87, p. 37 (Chile).

Parastacus agassizii Faxon, Proe. U.S. Nit. Mus., Fel). 17, 1898, 20, p. 690, pl. 70, figs. 4, 5 ('Talcahuano, Chils). Doflers, Sitzungsber: Akar\}. Wissensch. München, 1900, 30, p. 132 (Puerto Montt, Lago Llanquihué, Chile). Lecrz, Zool. Jahrb., Kupp., Nay 2, 1902, 5. p. 736 (Tumbes, Chile). Porter, Revista Chilena de Hist. Nat., Dee. 31, 1904, 8, p. 25S, P']. 9 (Contulmo and Chillán, Chile).

1 The error in the branchial formula of $P$. agassiziz as it appears in my paper in the Proe. U. S. NatMus., 1598, 20, p. 992 , has been pointed out hy Doflin. This cror was due to an unfortunate dislocntion of the table in printing, as is evident on comparing the table of the branchial arrangement in the genus Paractacus on p. 683. 
A single specimen of this species has been lately received at the Musenm of Conparative Zoölogy from V'alparaiso, C'hile.

As noted above, $P$. agassizii has been recorded from Lake Nahuel Huapi in Argentina by Ortmann (Proc. Amer. Philos. Soc, 41, p. 293). Specinens from this locality in the T. S. National Musem belong to a different although similar species, P. spinifrons (Phil.)? and Dr. Ortmann's determination should therefore be verificd.

I think that my $P$. agassizii is the salue species as the one previously deseribed by R. 1. Philippi in 1894 under the name of Astacus bimaculatus. Philippi's description is as follows:-

"Astaeus bimaculat us $\mathrm{Pl}$.

“A. cephalothorace utringue maenda nagna triangulari, albida notato; rostro dongato, peracnto, utrinque ante apicem dentieulo armato, unde lineac elevatae sensin divergentes nascuntur; "helis valde inaequalibus, sinistri majore; carpo ejus extus inflato, velut bullato, nargine suyeriore unispinoso; digitís gracilibus, denticulatis. Longit. corporis $72 \mathrm{~mm}$, chelae majoris $37 \mathrm{~mm}$.

"El color del cuerpo es oseuro siendo una mezela de negro virdoso i de pardo rojizo, como en las demas erpecies, i en cado lado se ve una gran mancla triangular blanquizea; su sujerfieir in lisa, pero las patas antrriores están eubiertas de granulaciones bistunte gruesas, que faltan solo cu la parte influla del carpo. El pico es easi tan largo como lit escana situada en la base do las antenas esteriores; se adelgaza paulatinamente en una punta mui iguda c inclinada. De carlo lado i mui cerea de la punta se notan dos dientecitos puntiagudos, de doncle parten listones bastante elevados i agudos, qui diverjen paulatinamente. In dientecito mui puntiagulo se obscrva tambien ante el borde te la órbita. Las patas anteriores son mui desiguales, la izquierda es muclio mas larga i sobre todo mas gruesa; por lo denas su liechura ('s la misma. En el borde superior del art ietlo tereero se nota una cspina, $\mathrm{i}$ dos o tres en el borde inferior. El carpo muestra tambien una o dos espinas en su borde superior, i en su lado esterior una hinehazon casi seni-globosa, mui notable (n el carpo izquierdo, nenor pero hien aparente en el derecho. La mano es mucho mas angosta i estirada que en las otras tres especies ehilenas, sobre todo los dedos, cuyo borde interior es finamente dentiulo. Las otras partes del euerpo no ofrecen nada de particnlar."

This description agrees pretty well with the species which I described as $P$. agassizii, but I do not know what Philippi means by asserting that the figure of Astacus fluviatilis in the Régue Animal of Cuvier (Disciples' Ed., pl. 49, fig. 2) is an exact representation of his new Chilean species. The colour of the specimens from Taleahuano had long since vanished when I described them. Porter, however, has more recently described the living colours of $P$. agassizii, and they seem to conform in the main to the colour scheme of $P$. bimaculatus as deseribed by Philippi:

"El color es en el dorso i flancos del cuerpo bruno-oliváecu, notándose en cuda costiudo del cefalotórax, por detras del surco eervical, una gran nuncha friangular de color amarillo limon cuyo vértice redondeado aleanza hasta la aréola, confundiéneluse en esta rejion con la del lado opuesto en muchos cjemplares. A veces se vé ademas una manclia redondeada de] mismo eofor a pocos milímetros del loorde anterior del earapaclo. Los tubereulillos escaniformes de las quelas lo mismo gue las espinitas del rostro 
son anaranjados, color que se observa en la parte inferior del cuerpo e inferior e interna de las patas. Estas últimas son de color bruno-oliváceo o bien oliváceo, especialmente en las quelas."1

With reference to the large triangular colour-patch on each side of the carapace of $P$. bimaculatus as described by Philippi and of $P$. agassizii as described by Porter, it should be observed that spots of the same shape and in the same place are often seen in erayfishes of divers kinds shortly after they are immersed in alcohol. These spots or blotehes are the result of the quick action of the alcohol on the thinnest part of the branchiostegites, which are bathed in the fluid on both sides, within and without. At first red, these spots afterwards fade into yellowish white, - the colour which ultimately pervades the whole of the body in specimens prescrved in spirits. One is almost inclined to suspect that the colour-pattern noted by Philippi and Porter was due to recent immersion of the specimens in alcohol.

\section{Astacus leniusculus Dana.}

A large number of specimens of this spceics were enllected for the U. S. National Museum in Johnson Creck, Portland, Multnomah Co., Oregon, by Messrs. Lyon and Benedict in May, 1905. The largest of these are upwards of five and one half inches long and demonstrate the fact that this species has as full, obese a form as A. troubridgii. There is considerable variation in relative width of the areola in these specimens. Of twenty-six specimens, eighteen $\left(7 \rho^{7}, 11 \%\right)$ have the right and left claws symmetrical, while in eight $\left(5 o^{7}, 3 \%\right)$ the claws are asymmetrical. In many of the asymmetrical individuals I think the smaller, slenderer claw, which may be either on the right or left side, is a new claw grown after the loss of the original one.

In a male specimen collected by MIr. S. E. Meek, in Ten-Mile Lake, Florence, Lane Co., Oregon, Oct. 17, 1896 (U. S. N. M. No. 23,121), the chelae have the form characteristic of $A$. leniusculus, and both pairs of post-orbital spines are developed as in that species, but in the shape of the rostrum and the proportions of the areola it agrees with A, trowbridgii. Another specimen in the U.S. National Museum from Astoria, Clatsop Co., Oregon, resembles A. trowbridgii in the breadth and inflation of the claws and the length of the posterior section of the carapace. Still another specimen in the same Museum (collected by Mr. Wm. Palmer) from the base of MIt. Tamalpais, Marin Co., Cal., taken altogether would be classed with $A$. trowbridgii; yet in the proportions of the posterior sec- 
tion of the carapace and the areola it agrees rather with $A$. leniusculus. As these two species inhabit the same region it is possible that they interbreed and produce hybrids.

\section{Astacus trowbridgil Stimpson.}

Astacus trowbridgii stands midway between A. leniusculus and A. hlamathensis. As it varies in one direction towards the former species, as has just been shown, so, on the other hand it passes through intermediate forms into the latter species. Such intermediate forms I have seen from Wilson Creek, Willapa, Pacific Co., and Littlerock, Thurston Co., Washington; and Sinslow River, Mapleton, Lane Co., and Wallowa Lake, Oregon. In dealing with small, immature individuals it is often difficult if not impossible to decide whether they should be assigned to A. klamathensis or to A. trowbridgii.

\section{Astacus klamathensis Stimpson.}

Plate 11, 12.

Astaeus klamathensis has a wide distribution in British Columbia, and in the states of Idaho, Washington, Oregon, and northern Cahifornia, in the vast area drained by the Columbia River and its tributaries as well as in the smaller streams that empty into the Pacific Ocean on the west side of the Caseade Range of mountains.

New localities:- IDaho: Indian Creek, Washington Co. Washington: Goldendale, Klickitat Co.; Granite Lake, Spokane Co.; Naches River, North Yakima, Yakima Co.; Crab Creek, [Douglas Co.?]; Creek near Hemp P. O.; Salmon River; Prairie Creek; North River; Willapa River, Holcomb, Nasel River, Nasel, Pacific Co. Oregon: Wallowa Lake, Wallowa Co.; Silver Creek, Harney Co.; Bcar River, Medford, Jackson Co., Johnson Crcek, Portland, Multnomah Co.; Nehalem River, Tillamrok Co. California: "Shasta River, near Montague, Siskiyou Co.; Cottonwood Creek, near Hornbrook, Siskiyou Co.; Priceland and Garberville, Humboldt Co.

In a lot of two dozen or more specimens of this species from Portland, Oregon, in the U.S. National NIuseum, a slight rariation from the typieal form is apparent in the lengthening of the rostrum and antennal scale and the more pronounced granulation of the chclae. In these regards they show a slight approach towards A. trowbridgii. Many of these individuals have lost their 
claws and grown them anew (see Plate 11, 12). It is interesting to note the restored claws never assume the normal form but are elongated and flattened. When both chelipeds have been lost and re-grown simultaneously, the result is an individual with perfectly symmetrieal elaws on the riglxt and left sides, so different in shape from the normal claws that one might easity be led to believe that it is a distinct speeies. Sueh a speeimen is shown in Plate 12, fig. 2. The restored claws in these eases assune an aneestral, less highly specialized from.

Astacus nigrescens fortis, subsp. nov.

Plate 7, Fig. 5, 9; Plate 9, Fig. 2.

Similar to Astacus nigrescens, from which it is distinguished by the following eharacters: - the sides of the rostrum converge more from the base to the tip; the areola of the carapace is narrower in proportion to its length; the chelae are shorter, broader, and more inflated.

Dimensions of a male:- length, $94 \mathrm{~mm}$; length of carapace, $49 \mathrm{~mm}$.; width of carapace, $26 \mathrm{~mm}$; length of abdomen, $45 \mathrm{~mm}$.; width of abdomen, $24 \mathrm{~mm}$; length of posterior section of earapace, $19 \mathrm{~mm}$.; width of areola, $6 \mathrm{~mm}$.; length of chela, $42 \mathrm{~mm}$; width of chela, $19 \mathrm{~mm}$.; length of dactylus, $22 \mathrm{~mm}$.

Types:-Fall River, Fall City Mills, Shasta Co., Cal., Aug. 29, 1898, Rutter and Chamberlain eoll., U. S. N. M., No. 44,404, $20^{7}, 3$ क , 1 juv.

Paratypes:- Hat Creek, Cassel, Shasta Co., Cal., Aug. 30, 1898, Rutter and Chamberkin eoll., U. S. N. M., 3 ㅇ.

\section{Astacus gambelir connectens, sulsp. nov.}

Plate 7, Fig. 6, 10; Plate 10, Fig. 1.

Similar to A gambelii (Girard), but different in these regards:- the rostrum is narrower and longer, with a longer acumen, and in eorrelation with this the antemal seales are mueh longer, their internal margin sloping gradually to the lengthened apical spine. The post-orbital ridges, though rudimentary, as in A. gambelii, develop a pair of prominent posterior spines as in A. nigrescens, while the anterior pair - the only post-orbital spines found in A. gambelii - are mueh more prominent than in that form. The ehelae are longer and slenderer than in A. gambelii.

Types:-U. S. N. M. No. 23,096, Snake River at Upper Salmon Falls, Idaho, Oet. 3, 1894, Evermann and Seovill eoll., $3 \sigma^{7}, 1$ \% 
Paratype:-Silvies River, Burns, Harney Co., Oregon, July 27, 1904, J. O. Snyder coll., 1 o. U. S. N. M.

This form bears the same relation to $A$. gambelii as $A$. leniusculus does to A. trowbridgii. In the development of the posterior pair of post-orbital spines it shows an affimity to $A$. nigrescens. It appears to be eonnected with $A$. gambelii by intermediate forms. A large male upwards of $3 \frac{1}{4} \mathrm{in}$. long in the U. S. National Museum, collected at the mouth of St. Joe Rirer, Coeur d'Alene Lake, Idaho, has the long narrow rostrum and the elongated hand and fingers of A.g.connectens, but the posterior pair of post-orbital spines are wanting, and specimens (also in the U. S. National Museum) from Warm Springs, Harney Co., Oregon, in most respects like typieal A. gambelii, show traces of the posterior post-orbital spines.

Dimensions of a male:- Length, $65 \mathrm{~mm}$.; length of earapace, $34 \mathrm{~mm}$.; length of abdomen, $31 \mathrm{~mm}$.; length of posterior section of carapace, $11 \mathrm{~mm}$.; width of areola, $5 \mathrm{~mm}$.; length of chela, $31 \mathrm{~mm}$; breadth of chela, $7.5 \mathrm{~mm}$; length of dactylus, $18 \mathrm{~mm}$.

Astacus leptodactylus Eschscholtz.

New locality:-Myslowitz, Cermany, IS93, Coll. Hofer, (U. S. N. M., No. 43,317) $10^{7}$.

Astacus pallipes italicus, subsp. nor.

Plate 8, Fig. 2.

In the Italian Crayfish as eompared with the typical form of $A$. pallipes from France, the margins of the rostrum are less convergent from the base to the lateral pair of spines, so that the breadth of the rostrum between the lateral spines is greater; the rostral aeminen, too, is longer. The sides of the abdominal segments end in a distinetly more acute angle. The chelae are more coarsely gramulated, the granulations or small tubereles separated by wider intervals. The anterior process of the epistoma is more broadly triangular. The antemnal scale is larger, longer, and terminates in a more prominent spine. The tip of the inner part of the gonopods of the male is produeed beyond the tip of the external part, whereas in A. pallipes the tips of the two parts are suberual. The telson is relatively broader.

Types:- U. S. N. M., No. 28,63S, River Sarno, Pompeii, Italy, June 10, 1900, Dana Coolidge coll. 11 ơ $^{7} 9$. 
Two specimens, $1 \sigma^{7}, 1$ o , in the U. S. N. M., No. 20,073, from Piobesi, near Turin, Italy, received from the Turin Zoölogical Museum agree in the essential characters with the Pompeiian specimens.

From these specimens I infer that the Cisalpine crayfishes constitute a marked geographical race, which in some respects (viz. the form of the rostrum, antennal scale, epistoma, and gonopords) shows an approach to Astacus astacus. It is not, however, liable to be confounded with that species, since the median carina of the rostrum is not denticulated, and the post-orbital ridges are entire, not broken up into an anterior and a posterior section as is the case with Astacus astacus. In the important matter of the branchial apparatus, moreover, A stacus pallipes italicus differs from $A$. astacus and agrees with $A$. pallipes in having but two rudimentary pleurobranchiae on each side of the body, upon the eleventh and twelf th body-segments. ${ }^{1}$

The crayfish found in the neighbourhood of Madrid, Spain, is in almost every respect like the typical French Astacus pallipes. It does, however, show an approach to the Italian examples in one regard, viz. an enlargement of the anterior process of the epistoma, and with this in a few specimens goes a tendency toward a broadening of the rostrum. It would nevertheless be an over-refinement to separate the Spanish crayfishes from Astacus pallipcs.

\section{Cambarus digueti Bouvier.}

Cambarus digueti Bouv., Bull. Mius. d'Hist. Nat., Paris, 1897, 3, p. 225.

Cambarus carinatus Faxon, Proc. U.S. Nat. Mus., Feb. 17, 1898, 20, p. 648.

New locality:- Ocotlan, State of Jalisco, Mexico (Field Mus. Nat. Hist.).

\section{Cambarus pilosimanus Ortmann?}

A young female crayfish, $35 \mathrm{~mm}$. long (M. C. Z., No. 7,405) was collected by Mr. J. L. Peters at Camp Nenzel, 36 miles from the mouth of the Hondo River, in the Territory of Quintana Roo, Mexico, March 27,1912 . It is closely affined to C. pilosimanus and C. williamsoni of Ortmann, if not identical with one of these. It presents certain features, howerer, that are not found in either of Ortmann's species; viz:- there are two well-marked spines, one above the

${ }^{1}$ This was determined by examination of the branchial apparatus of two examples from the type lot of $A . p$. italicus from the River Sarno. The rudimentary gills borne on the eleventh and trelfth somitrs have the form of reduced simple filaments representing the stem of the completely formed gill. 
other, on each side of the latero-anterior margin of the carapace, above the welldeveloped branehiostegian spines. This is a feature that one would not suspeet to be a jurenile mark, and it may denote specific diversity. There are, moreover, two sharp spines on the second segment of the antennae near the base of the antennal seales.

The chelae of the specimen collected by Mr. Peters are slender and nearly smooth, the fingers sparsely pilose, the spines of the carpus and merus well developed, as in young specimens of $C$. pilosimanus according to Ortmann. The anterior segment of the telson is three-spined on each side, the inner spine being very small; the median longitudinal rib on the dorsal face of the imner branch of the last abdominal appendages ends in a spine some distance from the posterior margin.

The type locality of $C$. pilosimanus is Coban, Guatemala. Dr. Ortmann also records one speemen, in the Museum of Natural History of Paris, from Belize, British Honduras, a loeality not very remote from the place where Mr. Peters got his specimen. Mr. A. S. Pearse (13th Ann. Rep. Mich. Aead. Sci., 1911, p. 110) has more reeently recorded it from Cuatotolapam, Canton of Acayucan, State of Vera Cruz, Mexico. The type locality of C. williamsoni is Los Amates, Province of Izabal, Guatemala.

\section{Cambarus mexicanus Erichson.}

New localities:- Mexico: Tuxtla Gutierrez, State of Chiapas (U. S. N. M., No. 30,580); Jalapa, State of Vera Cruz (Field Mus. Nat. Hist.).

Mr. A. S. Pearse ${ }^{1}$ has reently redeseribed this species under the name Cambarus rutheni, sp. nov, from the hacienda of Cuatotolapam, Cinton of Aeayucan, State of Vera Cruz, Mexico, altitude, 15 metres.

\section{Cambarus curensis Eriehson.}

New localities:- CuBA: Almendares River, Calabazar, Provinee of Habana (U. S. N. MI., No. 31,SS1); Unión de Reyes, l'rovince of Matanzas (M. C. Z., No. 7,633); Ciego de Avila, Provinee of Camagïey (Coll. J. T. Nichols).

There is a small specimen, a male, only $\frac{3}{4} \mathrm{in}$. long, in the U.S. National MLusemn (No. 28,625), fron Nueva Gerona, Isla de Pinos. It was colleeted by

${ }^{1}$ Report on the Crustacea collertel by the Iniversity" of Michigan - Wallere Expedition in the state of Vera Cruz, Mexico. Thirteenth Ann. Rej. Mich. Acad. Áci., 1911, 1, 110. 
Messrs. Palmer and Riley, July 8, 1900. It may be an immature specimen of one of the races of $C$. cubcnsis, or posibly a nearly allied species.

Since the above paragraph was written, and the specimen returned to the United States National Museum, Dr. A. E. Ortmann" has described as a new species, Cambarus (Procambarus) allinsoni, a crayfish eollected by Dr. A. Athinson in the tributaries of Rio de los Indins, Los Indios, Isle of Pines, May 25, 1910. It is closely related to C. eubensis, from which it differs principally in the much less dilated inner face of the copulatory organs of the male.

\section{Cambarts cubensts consobrinus Salissure.}

Cambarus consobrinus Sauss., Rev. ot Mag. Zool., 1857, nér. 2, 9, p. 101 ; 11 mm. Soo. Phys. Hist. Nat. Gent̀ve, 1855,14, p. 457 , pl. 3, fig. 21.

C'ambarus cubersis consobrime FAxon, Bull. Mus. Comp. Zoül., Oct. 1912, 64, p. 458.

In this form of the Cuban Crayfish the rostrum is narrower than in the typieal $C$. cubensis, more deply coneave above, its margins more distinctly raised and less convergent between the base and the pair of lateral spines near the distal end; these lateral rostral spines, moreover, are much better dereloped than in the typical form, and the rostral acumen is longer; the post-orbital ridge is more prominent, flistinctly grooved along its outer face, and produced anteriorly into an acute spine muel more strongly emphasized than in the typical c'. cubensis; there is, too, an evident lateral spine on each side of the carapace, on the hind border of the cervical groove, - a spine which is not present in $C$. cubensis cubensis. The external sexual organs are alike in the two forms.

Nine specimens of this erayfish $\left(50^{7}, 4\right.$ \& $)$, MI. C. Z., No. 7,343, were seemed by Dr. Thomas Barbour from lads who were using them for fish-bait, at san Antonio de los Baños, in the interior of the Province of Habana, Cuba, April, 1909.

Cotypes of Saussure's Cambarus consobrimus are now dispersed anong the Museums of Geneva, Paris, Berlin, and Washington. It is very likely that Saussure's material inchuded some of the typical form of $C$. cubensis; his description and figures, nevertheless, were grounded on the form with long rostral acumen, and distinct rostral and lateral thoracic spines; the type locality of consobrimus, moreover, as specified by Sanssure, is the central part of the island.

In the cotype in the U. S. National Nuseum (No. 20,684, ex Mus. Geneva),

'A New Species of the Genus Cambarus from the lsle of P'ines. Ann Carnegie Mus, May 5, 1913. 8, p. $414-417$. 
a male, dried and transfixed with a pin, the rostrum is abnormal, the right margin thereof being pared away toward the tip, carying with it the right matrginal spine. This deformity was evidently present in the living specimen. On the left side the marginal rostral tooth or spine is well developed, as are also the spines at the anterior end of the post-ocular ridges. The lateral thoracio spines too are fairly well marked.

\section{Cambarus cubensis rivalis Faxon.}

Camburus cubensis rivalis Fax., Bull. Mus. Comp. Zoöl., Oct., 1912, 54, p. 459.

Differs from typical $C$. cubensis (which lives in the low country, near the sealerel) in having a much shorter and broader areola, a shorter, broader, and more heavily granulated claw; the sides of the rostrum, furthermore, are more nearly parallel and they bear a pair of distinct lateral spines at the base of the acumen. In so far as the rostrum is concerned this subspecies resembles $C$. $C$. consobrinus, yet it differs from consobrimus by having a short and wide areola and by the absence of lateral thoracic spines. The sexual parts are like those of C. cubensis.

Length of an origerous female, $44 \mathrm{~mm}$., length of carapace, $21 \mathrm{~mm}$., length of areola, $6 \mathrm{~mm}$., breadth of areola, $2 \mathrm{~mm}$.

This form is an inhabitant of the mountain streams of western Cuba. The extent of its distribution remains to be determined by further exploration of the island. The type specimens (AI. C. Z. No. 7,406), two males of the secourd form and three females, were eaught by Dr. Thomas Barbour in a mountain stream near San Diego de los Baños, in the l'rorince of l'inar del Rio, Feb., 1912. There are also specimens in the U.S. National Museum from the same place (Nos. $28,626,25,627$ ) and also from a mountain brook north of the town of lintur del Rio (Nos. 23,656, 23,657).

\section{Cambarus simulans Faxom.}

New localitics:- Texas: Sourlake, IIardin Co. (U. A. N. M.). Irkansas: Saline R., Benton, Saline Co. (U. S. N. M.). OkLaHout: Mount Scott, Comanche Co. (U. S. N. M.).

Under the name Cambarus gallinus this species has been recorded by Messr's. T. D. A. Cockerell and Wilmath Porter (Proc. Acad. Xat. Sci. Phila., 1900, p. 434-435) from the Gallinas River at Las Vegas, San Niguel Co., in lakes at Watrous, Mora Co., and from Roswell, Chaves ('o., in the State of New Mexico. 
Its range is now known to inelude the fire states, Texas, Arkansas, New Mexico, Oklahoma, and Kansas.

\section{Cambarus gracilis Bundy.}

New localities:- Iturnors: Abingdon, Knox Co. (U.S. N. M.); Oquawka, Henderson Co. (U. S. N. M.).

\section{Cambarus hagenianus Faxon.}

Plate 1; Plate 7, Fig. 1, 7.

Cambarus carolinus HaGeN, nee Erichson.

Cambarus hagenianus Faxon, Proc. Amer. Acad., 1884, 20, p. 14.

This species has been hitherto known only through the type specimen in the Museum of Comparative Zoölogy (No. 232), a male of the first form received early in the history of the Museum from Professor Lewis R. Gibbes of Charleston, S. C. The United States National Museum has recently received it in ample numbers from the Agrieultural College, Oktibbeha Co., Miss., and also from Muldon, Monroe Co., Miss., and Farmdale, Ala. It is a pest to the cotton growers of these regions, riddling the fields with its burrows, and devouring the young plants; to a less degree it is destruetive to young blades of maize or Indian corn. ${ }^{1}$

Hagen's Crayfish attains to a length of three inches. It is nearly related to $C$. gracilis Bundy, replacing that species in more southern localities. In $C$. gracilis the sides of the rostrum are more nearly parallel; the sub-orbital angle, which is prononneed in C.gracilis, is wanting in C.hagcnianus. The branchioeardiae lines, although contiguous in both $C$. gracilis and $C$. hagenianus for a considerable distance, obliterating the areola, are united for less distance in the former than in the latter; the abdomen is much broader in C. gracilis, and the longitudinal rib on the upper side of the inner branch of the last pair of abdominal appendages terminates in a spine which lies some distance from the posterior margin, while in $C$. hagenianus this rib extends elear to the margin, where the spine projects freely. The gonopods of the first form male are formed after a similar fashion in C. hageniamus, C. gracilis, and C. simulans; there are three terminal teeth (one of which is compressed or laminate) in C. gracilis and $C$.

${ }^{1}$ Sere U. S. Depart. Agric., Rept. Bureau Biol. Surv, for 1911, p. 9; and A. K. Fisher, Crawfish as Crop Destroyers, Yearbook U. S. Depart. Agric. for 1911, 1912, p. 319-324, pl. 22. 
simulans, but the smallest of the three is smaller in $C$. simulans than in C.gracilis and lacks the horny texture; in C. hagenianus the truncate end of the gonopods bears but two teeth.

In the second form of the male the gonopods are less perfectly finished at the tips, the terminal teeth being blunter and membranous. The annulus ventralis of the female C. hagenianus is much like the annulus of $C$. gracitis, being produced on each side of the median line into a prominent tuberele, each tubercle tending to denticulation.

The specimens from Muldon, Miss, are peculiar in having a beard along the internal border of the upper face of the hand in the males, as in Cambarus barbatus and Astacus gambelii.

Colour of living specimens from Muldon, Miss.:- Male (Plate 1, fig. 2), metacarapace violet-gray with round greenish spots on the branchial regions; procarapace greenish, dashed with red anteriorly; abdomen light orange, with two longitudinal rows of irregular olive spots; chelae and earpus olive, the tubereles and granules green; fingers and antennae orange, beard whitish. Female (Plate 1, fig. 1), metacarapace bluish; procarapace, abdomen, and chelae tending to green at the expense of the orange tints.

Few eases of colour differences correlated with sex have been noted anong Crustacea. See Andrews, Zool. Anz., Apr. 25, 1911, 37, p. 40I.

\section{Cambarus versutus Hagen.}

New locality:- Auburn, Lee Co., Alabama (M. C. Z.).

\section{Cambarus blandingit (Harlan).}

New localities:-Virginia: Cape Henry, Princess Anne Co. (U. S. N. M.). North Carolina: Mattamuskeet Lake, Hyde Co. (U. S. N. M.); Reedy Fork, Cape Fear River, Greensboro, Guilford Co. South Carolina: Charleston Co. (U. S. N. M.).

\section{Cambarus blandingil acutus (Girard).}

New localities:- Ilunors: Greathouse Creek, Wabash Co. (U. S. N. M.). Arkansas: Bruce Lake, Little Roek, Pulaski Co. (U. S. N. M.). Maryland: Fulton Co. (U. S. N. M.). Mississippi: Rosedale, Bolivar Co. (U. S. N. M.). Louisiana: Frierson, De Soto Co. (U. S. N. M.). Texas: Angelina River (U. S. N. M.). 
A large male, form I., in the U. S. National Museum, eollected in 1897 in the Mississippi River at. New Orleams, La., measures $5_{8}^{3}$ in. from the tip of the rostrum to the end of the telson, the chelipeds are $6 \frac{7}{8} \mathrm{in.}$ long, the chelae $3_{4}^{3} \mathrm{in}$. long. The dimensions of a male of about the same size were given on page 23 of my Revision of the Astacidae. This specimen also eame from New Orleans (M. C. Z., No. 3,327) and is the same one whose measure was given by Dl" Hagen on page 37 of his Monograph of the North American Astacidae with an errour of over an inch in the length.

\section{Cambarus hayi Faxon.}

New locality:- Agricultural College, Oktibbeha Co., Mississippi (U. S. N. M.).

\section{Cambarus fällax Hagen.}

New localities:- Flonida: Auburndale, Polk Co.; Kissimmee River, between L. Hateh and Kissimmee, Oseeola Co.; Lake Monroe, near Sanford, Orange Co.; St. Johns R., at Palatka, Putnam Co.; St. Johns River at Beecher' Point.

Cambarus acherontis Lömmberg.

New locality:- Eustis, Lake Co., Florida, 2 f. II., 7 q, in U. S. N. M.

\section{Cambarus clareit Girard.}

New lnealities:- Texas: Fort Clark, Kinney Co.; Seguin, Guadalupe Co.: San Mareos, Hays Co.; Houston, Harris Co.; Corpus Christi, Nueces Co.; Angelina River; Beamont, Jefferson Co. Loussinna: Lake Lepourde, Morgan City, Saint Mary Co.; Melville, Saint Landry Co.; Frierson, De Soto Co. Arhansas: Little Rock, Pulaski Co., (1 q coll. by O. P. Hay, U. S. N. M., No. 19,762). Nll of the above are in the U. S. National Muscum.

As noted in my Rerision of the Istacidae, p. 26, specimens of C. clarkii from New Orleans, La., differ slightly from the typieal specimens from western 'Texas in having the branchin-cardiae lines in close apposition for' a long distance through the procarapace, obliterating the areola and redueing the size of the anterior and posterior triangular fields. This is well shown in Roetter's beautiful drawing of a specimen from New Orleans in Hagen's Monograph of the North Ameriean Astacidae, Pl. 4. 


\section{Cambartes charkit podeninstlanus, mbep. nov.}

The examples of Clark's crayfish found in the peninsular portion of the State of Florida differ slightly, albeit constautly, from the typical Texas form in heing smoother, in haring a more tapering rostrun, and a shorter and broader antennal seale; there is moreorer a slight difference in the shape of the tip of the male sexual appendages: the anterior terminal tooth being narrower and more acute than in the typical form in which this tooth is broader, more laminate and less acute at the tip; in the Foridan subspecics, too, the anterior half of the telson bears on each side from three to five spines, while in the typical C. clartii there are but two spines on each side.

Type: M. C. Z., No. 3,530, 1 \% f. II. Three miles below Horse Landing, St. John's River, Florida, Feb. 9, 1869, J. A. Allen.

There are a good many speeimens of this subspecies in the U. S. National Museum collected by W. C. Kendall at Beecher's Point, st. John's River, Fla., in February and March, 1S97, Nos. 28,587, 28,5S9.

\section{Cambarus megmanni Erichson.}

This species is still imperfectly known; Erichson's type, which came from Mexico, is no longer extant; it was described as having hook so both the third and fourth pairs of legs in the male. I female individual from Mexico, in the collection of the Academy of Natural seiences of Philadelphia, was referred to this species by Dr. Hagen and myself, although with some doubt on account of the want of male spccinens. In 1906 Dr. Ortmann (Proc. Wishington Acad. Sci., 8, p. 15-19) described and assigned to this species a male belonging to the Philadelphia Lademy, collected by Professor E. D. Cope in 1855 in Lake Xochimilco, south of the City of Miexico, in the Federal 1)istrict; in this specimen the legs of the third pair are furnished with a very small tubercle only, while those of the fourth pair are armed with a strongly developed hook.

Four specimens, three male, one female, recently collected by Mr. W. M. Mann at San Miguel, State of Hidalgo, Mexico, and now in the Museum of Comparative Zoölogy, conform to Ortmann's description of the Cope specimens, barring the fact that there is no vestige of even a tubercle on the third pair of legs of the male, the fourth pair alone being provided with hooks; these specimens may represent an undescribed species, but on account of the sad dearth of requisite material and the loss of the type of $C$. wiegmanni the elueidation of this question must needs be deferred to a later time. 


\section{Cambarus viae-viridis, fp. nov.}

Plate 5.

Male, form I: - Rostrum long, triangular, plane abure, margins raised so as to form a sharp rim, destitute of lateral spines or angles; acumen strongly deflexed, not clearly defined; a shallow depression or foveola at the posterior end of the rostrum. Carapace punctate above, finely granulate on the sides; post-orbital ridges terminating bluntly before; cervical groove simuate, interrupted on each side; no lateral spine, branchiostegian spine minute; areola narrow, equal in length to about one half the distance from the cervical groove to the tip of the rostrum. Abdomen punctate, pleural angles rounded off, hind border of anterior section of the telson bispinose on each side. Anterior process of the epistome triangular, with slightly convex sides. Antemnal scale short and rery broad, trumeate at the anterior end. C'helipeds of moderate length; upper margin of the meros serrated, below there are two series of spines; carpus tuberculate and spinulose on the inner face; chela of moderate proportions, with slender fingers; superior margin of the hand spinulose, outer and inner faces spinuIoso-tuberculate; dactylus spinulose through the proximal quarter of the superior border. Basal segment of last pair of thoracic appendages provided with a crest which is produced on the inner side into a projecting tooth. Third segment of third and fourth pairs of legs hooked. First pair of abdominal appendages rather short, tip truncate, outer part furnished with a prominent horny tooth and two minor denticles, inner part terminating in a straight spine, the end of which does not reach to end of the largest tooth of the outer part.

Length $45 \mathrm{~mm}$., carapace $23 \mathrm{~mm}$., areola $7.5 \mathrm{~mm}$., width of areola $5 \mathrm{~mm}$. Length of hand $17.5 \mathrm{~mm}$. Length of palm $\mathrm{S} \mathrm{mm}$, width of paln $5.5 \mathrm{~mm}$. Length of fingers $9.5 \mathrm{~mm}$.

Annulus ventralis of the female transversely broad, with a deep sigmoid suleus which is open in front.

St. Francis River, Greenway, Clay Co., Arkansas, Aug. 1894, S. E. Meck coll. M. C. Z., No. 7,336, 10. specimens, or and 옹

This species is allied to Cambarus evermanni Fax. from Pensacola, Fla. It differs in having the upper surface of the rostrum flatter, with depressed acumen, the areola narrower, the hand broader, and also by the different character of the tips of the male appendages. It falls into the group of species represented by C. evermanni Fax., C. barbatus Fax., C. wiegmanni Erichs., C. hinei Ortm., and $C$. alleni Fax. 
Cambarus alleni Faxon.

New localities:-Florida: Fort Florida, Volusia (o. (M. C. Z.); ponds near Tampa, Hillsboro Co. (U. S. N. M.); Lake Butler, Talrpon Aprings, Hillsboro Co. (U. S. N. M.); Iake Yohopekalize, Kissimmee, Osceola Co. (U. S. N. M.).

\section{Cambarus shufeldti Faxon.}

'There is a male of this speeies, $21 \mathrm{~mm}$. long, in the U. S. National Museun, collected by Robert Kennicott at Cairo, Ill. It has been previously known only from the original type lot collected near New Orleans, La., by Dr. R. W. Shufeldt in $18 S 3$.

\section{Cambarus montezumae Saussure.}

New locality:- Aeambaro, State of Guanahuato, Mexico (Field Mus. Nat. Hist.).

\section{Cambarus montezumae dugesil Faxon.}

New localities:- Mexico: Chaleo, State of Mexieo; Celaya, State of Guanahuato; Lake Quitzeo, Huingo, State of Michoaean; La Barea and Lagos, State of Jalisco; all of these are in the Field Museum of Natural History; they were collected by Prof. S. E. Meek in 1901.

\section{Cambarus montezumae chapalanus Faxon.}

New localitics:- Patzcuaro and Zirahuen, State of Miehoacan, Mexico (Field Mus. Nat. Hist.).

\section{Cambarus montezumae occidentalis Faxon.}

Two males, collected by Prof. S. E. Meek, in Lake Quitzeo, Ituingo, State of Michoacan, Mexico, and now deposited in the Field Museum of Natural History, appear to belong to this subspecies. It has been alleady recorded from the same place by Dr. A. E. Ortmann (Proc. Washington Acad. Sci., 1906, 8, p. 20). 


\section{Cambarus sloanit Bundy.}

Four specimens, males of the scoond form, collected hy MIr. W. P. Hay between I'aoli and Wyandotte, Ind. (U. S. N. M., No. 19,776), and detemined by Mr. Hay as C. slomii, differ in some important regards from the types of C. sloanii from New Albany, Ind.: The tip of the immer ramus of the gonopods is not deflected inward so strongly, the rostrum is longer, with a longer acumen, the large claws are distinctly narrower, with relatively longer fingers, and the onter row of spines on the lower face of the merus of the chcliped is reduced to a single terminal spine. These specimens perhaps represent a new species or subspecies, but in the absence of the first form of the male and the female I refrain from naming it.

\section{Cambarus affinis (Say).}

New loculities:-Marrland: Sam's Creck, Frederick Co. (U. S. N. M.); Little Pipe Creck at. Union Bridge and near New Windsor, Carroll Co. (U.s. N. M.); Northwest Branch near Hyattsville, Prince Georges Co. (U. S. N. M.). Virginia: Orkney Springs, Shenandoah Co. (U. S. N. M.). Massachusetts: Bancroft's Pond, Brown's Pond and Epring Pond, Peabody, Essex Co. (MI. C. Z.); Mansfield Pond, Great Barrington, Berkshire Co. (M. C . Z.);

This species, whose real home is in the rivers that flow into the Itlantic in New Jersey, Pennsylrania, Maryland and Virginia, is now well established in the town of Peabody, Essex C'o., Mass. How or when it got there I do not know. The first report of it came to me in 1901 when the late. J. H. Sears brought me a specimen $90 \mathrm{~mm}$. long, which he har caught in Bancroft's Pond, Peabody, on the the of Iugust of that year. In Sept., 1911, Dr. John C. Phillips sceured a good many (43) specinens from spung Pond, Brown's Pond and Bancroft's Pond in Peabody, some of them attaining a length of $98 \mathrm{~mm}{ }^{1}$ Dr. Phillips's collector searched for crayfishes in the following ponds in Essex County with negative results:- Ilood's, Stephens, Four-Milc, Stiles's, Spofford's and Perley Pond in Boxford, and Chebaceo, Beck's, Round and Ciravelly Ponds in Hamilton.

On the 14th of Jume, 1912, I captured a female C. affinis, with young under her abdomen, in Mansfield Pond, Great Barrington, Berkshire Co., Mass.

${ }^{1}$ The largest specimen of $C$. affinis in the Museum of Comparative Zoölogy, a female from Havre de Grace, Ml., No. 180, collected in 185t, measures $12 t \mathrm{~mm}$. from the tip of the rostrum to the ent of the telson. This is the inclividual figured, slightly lengthened. (m Plate 5 of Ingen's Monograph of the North American Astacidae. 
I was told in Great Barrington that these animals were introduced 10-15 years ago into Lake Buel, on the borders of the neighlooring towns of MIonterey and New Marlborough, by anglers who were using them as fish-bait, that they are now exceedingly mumerous in Lake Buel and have been probably transerred thence to neighboring ponds by boys.

C. affmis has been introduced into Europe as a piscicultural cxperiment in acclimatization at the Station Agricole at Féeamp, France, ${ }^{1}$ and elsewhere.

This species has also been found of late in Central Park Lake, New Jork City, and in Prospect Park Lake, Brooklyn; it has also been reported as introduced into a lake in East Hampton, Middlesex Co., Comn. (Bull. N. I. Zoöl. Soc., Nov. 1912, 16, p. 924).

\section{Canbarus propingues Girard.}

New localities:- NEw York: Mumsville, Madison Co.; Glemmark Creck, North Rose, Wayne Co.; Chammont River, Bataria, Cicncsee Co.; Seneca Lake; Nud Creek and Saint Lawrence Rivel, Cape Vineent, Jefferson Co.; Griffin's Creek, Chaumont, Jefferson Co.; Stony Island, Jefferson Co.; Stony Creek, Henderson Harbor, Jefferson Co.; Sandy Creek, North Hamlin, Monroe Co.; Nine-Mile Point, Webster, Monroc Co.; Selkirk, Oswego Co.; Marsh Creek, Point Breeze, Orleans Co.; Tonawanda C'reek; Canada Way Creck, Dunkirk, Chautauqua Co.; Tan Buren Point, Chautauqua Co.; Nilver Creck, Chautauqua Co.; Cattaraugus Creek. Omı: Cowles Creek, Crenera, Ishtabula Co.; Conneaut Creek, Kingsville, Ashtabula Co.; Rocky River, Olmsted Falls, Cuyahoga Co.; Port Clinton, Ottawa Co.; Catawba Island, Ottawa Co.; Lakeside, Ottama Co. Indians: Tippecanoe River, Delong, Fulton Co, sims, Grant Co.; Winona Lake, Kosciusko Co.; Eagle Lake, Waraw, Koseiusko Co.; Eransville, Vanderburg Co.; Eel River and Blue River, Columbia City, Whitley Co. Itunots: Wabash R., Hutsonville, Crawford Co. (Mus. Comp. Zoöl.): Kankakee River, Momence, Kankakee Co.; Illinois River, Havana, Mason Co. Michigav: Raisin River, Nonroe, Monroe Co.; Black Creck, Lexington, Sanilae. Co.; Port Sanilac, Sanilac Co.; Crand River below Lansing, Ingham Co.; Wolf Lake, Jackson Co.; Long Lake, 8 miles north of Ilpenat, Mpena Co.; Tawas City, Iosco Co.; Au Sable River, Au Sable, Iosco Co.; mouth of C'arp River, 12 miles from Straits of Mackinac; Nullet Lake, Cheboygan Co. (U. S. N. M.). Mexico: Jimenez, State of Chihuahua (Field Mus. Nat. Hist.).

The locality Jimenez, Mexico, is such an extraordinary one for this species

'Acclimatation des Eerevisses Américaines. Rerue Scientifque, Jan. 9, IS97, scr. 4, 7, p. 56. 
that one might well suspect some error if the origin of the specimens were not so well attested. Seven specimens, males of the first form, now in the Field Museum of Natural History, were collected by Mr. S. E. Meek, together with four female C. virilis, June 9, 1901, in the drainage of the Rio de los Conchos, one of the southern tributaries of the Rio Grande. They were picked out from among the fishes which were the chief object of Mr. Meck's exploration of Mexico and sent to me for determination in Jamuary, 1902.

The conditions obtaining at the time and place of their capture are thus described by Mr. Meek in his account of the fishes secured during his Mexican explorations of $1901:^{1}$

"At Jimenez the Rio Conchos was nearly iry. Our collections were unade from a few deep holes about two miles below the eity. These contained a large amount of aquatic vegetation, which made collecting difficult and unsatisfactory. The water was very clear, and in the deeper places were seen many large suckers which we were unable to capture. Sunfishes were very abundant. All of these streams beeme large and deep in the rainy season, at which time the Riu Conchos at Jiminez becomes two hnudred or more feet in width and as moch as fifteen feet in depth."

\section{Cambarus propingues sanibornit Faxon.}

New localities:- Онюо: Black River, Elyria, Lorain Co.; Hudson, Smmmit Co.; Vermilion River; Cuyahoga River, Kent, Portage Co.; Dover Creek, Dover, Cuyahoga Co. West Virginia: Horse Creek (U. S. N. M.).

\section{Cambarus obscurus Hagen.}

Newlocalities:- New York: Cattaraugus Creek. West Virginia: Cassity, Randolph Co.; Cheat River, Ises Ferry, Sand Run, Childer's Run, and Trubie's Run, near Buckhamnon, Upshur Co.; Queens, Upshur Co.; Weston, Lewis Co.; Hacker's Creek, near Janelew, Lewis Co.; Ten-Mile Creek at Lumberport, Harrison Co.; Decker's Creek above Morgantown, Monongalia Co. (U. S. N. MI.).

Cambarus obscurus is an abundant river species in the Upper Ohio River Basin in northern West Virginia, and western Pennyslvania. It is also found in the Lake Erie and Lake Ontario drainage in the states of Pennsylvania and western New York, and in Wills Creek, an affuent of the Potomac River, at Hyndman, Bedford Co., Pa., and Ellershie, Allegany Co., Mrd. ${ }^{2}$ In the U.S.

${ }^{1}$ A Contribution to the Idnthyology of Mexico. Field Colunbian Musenm, Publ. 65, Zoöl. Ser., May, 1902, 3, p. 65.

${ }^{2}$ Ortmann, Mem. Carnegie Mus., 1906, 2, p. 445. 
National Museum there is a female crayfish (No. 22,5IS) collected by D. S. Jordan in northern Wisconsin which looks like this species, but the locality is an extraordinary one for this species and should not be accepted as authentic until confirmed by securing more material.

\section{Cambarus rusticus Girard.}

New localities:- Iowa: West Fork of Des Moines River, Spring Vale, Humboldt Co. (M. C. Z.). Oııo: Sandusky River, Fremont, Sandusky Co.; Presque Isle, Perrysburg, Wood Co. Indans: Moot's Creek, White Co.; Salmonie River, Monnt Etna, Huntington Co. Kentuckr: Salt River. Tennessee: Richland Creek, Nashville, Daridson Co. (U. S. N. M.).

\section{Cambarus neglectes Faxon.}

New localities:-Mrssouri: Indian (reek, MeDonald Co. (U. S. N. M.). Colorado: Republican Rivel, Wray, Iuma (o. (M. C.Z.).

Canbarus spinosus gulielmi, subsp. nov.

Cambarus spinosus IAY, Proc. U. S. Nat. NHus, 1902, 25, p. 439 (nec Bundy).

Cephalothorax shorter than the abdomen, densely punctate above, granulate on the sides, the gramules largest on the hepatic region where they assume the form of small tubercles; the whole surface, but more particularly the sides, is clothed with fine setae arising as pencils from the pits of the dorsal surface and the granules of the sides; the rostrum is deeply excarated above, its sides parallel from the base to the lateral pair of teeth at the base of the moderately long, triangular apex; the post-orbital ridges are prominent and provided with a small tooth at the anterior cnd; the sub-orbital angle is obliterated, but there is a well-dereloped branchiostegian spine, as well as a lateral spine on the cervieal groove; the section of the carapace behind the cervical groove in the median dorsal line is a little less than one half the distance from the cervieal groove to the tip of the rostrum. Areola of moderate width. The anterior segment of the telson bears two spines on each side. The anterior process of the epistome is moderately broad, its sides convex, its anterior angle rounded off. The antennal flagella are long and slender,- - longer than the body; the scale or scaphocerite is of moderate width, widest at a point a little anterior to the middle. The chelae, like the carapace, bear numerous setae springing from the pits and 
tubereles on its surface; the inner border of the hand is furnished with squamoid tubercles disposed for the most in two longitudinal rows; along the distal half of the outer border of the hand there runs a low, but well-marked, carina; the dactylus is tubereukte on its free border, blunt-toothed (like the immolile finger) along its prehensile edge and ridged longitudinally along its outer face; the earpus is armed with an acute spine on the middle of its internal border, and with a small tuberele at each end of the same border; below, the median carpal spine is well pronouneed and there is a small acute spine at the inferior point of articulation with the propodus; the two customary spines are present near the anterior end of the upper margin of the merus; the outer of the two rows of spines on the lower face of the merus is reduced to two at the distal end. The dorsal carina of the inner branch of the last abdominal appendages terminates in a tooth a little distance within the hind margin.

The gonopods, in the seeond form of the male, are long and straight, reaching forward, when the abdomen is flexed, as far as the hasal segments of the second pair of legs; their rami are rather thick, blunt at the tip, and the outer one is but a trifle longer than the inner one; when viewed from the inner side the two rami are fused up to within a short distance of the end of the organ.

The ammulus ventralis of the female is bituberenlate in front, unitulereulate behind, the anterior and posterior walls being separated by a transverse fossa which is divided longitudinally by the sigmoid fissure.

Dimensions of a female:- length, $73 \mathrm{~mm}$., length of earapace, $37 \mathrm{~mm}$., length of rostrum from tip to a level with the post-orbital spines, $11 \mathrm{~mm}$., width of rostrum at base, $5 \mathrm{~mm}$., length of areola, $12 \mathrm{~mm}$., widt th of areola, $2 \mathrm{~mm}$., length of cheliped, $54.5 \mathrm{~mm}$., length of chela, $27.5 \mathrm{~mm}$., hreadth of chela, $12 \mathrm{~mm}$., length of dactylus, $16 \mathrm{~mm}$.

This crayfish is closely related to the Cambarus spinosus of Bundy, but is different in the following respects:- the body is more villous, the metacarapace longer in proportion to the procarapace, the anterior process of the epistome is much narrower than in the types of Bundy's species and (what has most weight in regarding it as a subspecies) the external sexual organs are elearly different. The gonopods in C. s. gulielmi heing shorter, the rami thicker, blunter, nearly ectual in length, and separate for but a short distance from the tip, while in C. spmosus the rami are slender, pointed, the onter one exceeding the inner by a great distance and the split between the two parts involving a large part of the length of the organ. The annulus ventralis of the female, though of the same type as that of the typical C.spinosus, differs slightly in having a more open transverse fossa. 
The villosity may be an evanescent character, as it is a rondition often apparent in indiriduals that have recently undergone a moult; at a later period the setae are apt to disappear hy attrition.

U. S. National Museum, Nos, 26,379, $12 \sigma^{7}$ f. II., 14 . From a small stream flowing from a pond fod by the cave strom known as John Ross sipring, near Rossville, Walker Co., Georgia, Aug, 23, 1901, William Perry Hay coll.

\section{Cambarus putwan Faxon.}

Upward of one hundred specinens of a erayfish closely resembling (. putnami were collected by Mr. Wr. P. IIay in southwestern West Virginia in the summer of 1900 . They were found in the shathower parts of streams, wsully under flat stones, - in Barrenshe Creek, near Perryville, U. N. N. M., No. 25,018, 28,6I3, and Iforsepen Creck, (U. S. N. M. No. 28,612) and War Creek (U. S. N. M. No. 28,614). In these specimons the rami of the gonopods are a trifle longer than in the types of ( . putnumi from Kentucky, the rostrum, moreorer, shows a pretty constant faint carina on its upper surface, neas the tip, and the anterior angle of the epistome is truneate. These peculiarities do not seem to me important enough to separate this form nominally from $C$. pulnami.

According to Mr. Hay's notes their eolour when alive was olive-green on the dorsal surface of the body and chelipeds, changing to rinaceous on the sides, under parts and other appendages; the tips of the fingers were horn-yellow and preceded by a rather broad band of dark orange-red.

\section{Cambarus longidigitus Faxon.}

New locality:- James River, springfield, Cireen Co., Mistouri (U. S. N. M. No. 20,856).

James River, Missouri, without further specification of locality, is the type locality of Combarus whitmani sitrole, ${ }^{1}$ which as far as can be seen from the description is the same as $C$. Iongidigitus.

\section{Cambarts virilis Hagen.}

New localities:- Indins: Praire Creek, scotland, Green, Co. Itunoms: Henderson Co.; Kankakee River, Momenere, Kankaken Co. Munnax: Belle Isle, Detroit, Wayne Co.; Pigon River, Caseville, Ifuron Co.; Bird Creek, Purt

${ }^{1}$ Univ. Cincinnati Bull. No. 10, 190:3, p. 24 
Austin, Huron Co.; Sand Beach, Huron Co.; Pinnebog River, Port Crescent, Huron Co.; Mud Creek, Bay Port, Huron Co.; Black River, near Port Huron, Saint Clair Co.; Pine River, West Harrisville, Aleona Co.; Au Sable River, Au Sable, Iosco Co.; Rabbit's Back Creek, 5 miles above Saint Ignace, Mackinac Co.; 12 miles from Straits of Mackinac. Minnesota: Deer River, Itasca Co.; Lake of the Woods. North Dakota: Borit's Ford, Cheyenne River. Nebraska: Lineoln Creek, York, York Co. Missour1: Clinton, Henry Co. (U. S. N. M.). Colorado: Republiean Rivel, Wray, Yuma Co. (M. C. Z.). Mexico: Jimenez, State of Chihuahua (Field Mius. Nat. Hist.).

The Mexican specimens (four females) were collected by MIr. S. E. Meck from deep holes, Rio de los Conchos, about two miles below Jimenez, June 9, 1901. For the circumstances of their capture, see under Cambarus propinquus, page 373,374 .

Cambarus manunis Hagen.

Plate 2, 6 .

New localities:- Nebraska: Norfolk, Madison Co. (U. S. N. M.); Elkhorn River, Fremont, Dodge Co. (U. S. N. M.); Omaha, Douglas Co. (M. C. Z.). Missourl: Lake City, Jackson Co. (M. C. Z.). Iowa: West Fork of Des Moines River, Spring Vale, Ifumboldt Co. (M. C. Z.). Mtchigan: Pine River near Thest Harrisville, Alcona Co. (U. S. N. MI.); Caseville, Huron Co. (U. S. N. M.); mouth of Bunce River, south of Port Huron, St. Clair Co. (U.S. N. M.). Ilunors: Wabash Co. (U.S. N. M.); Indian Creek, Abingdon, Kínox Co. (U.S. N. M.); Illinois River, Havana, Mason Co. (U.S. N. M.). Oнı: Cedar Point, and Presque Isle, Toledo, Lucas Co. (U. S. N. M.); Toussaint River, ten miles below Port Clinton, Ottawa Co. (U. S. N. M.). New York: Pond near the mouth of Cattarangus Creek, Chautauqua Co. (U. S. N. M.); Silver Creek, Chantauqua Co. (U.S. N. M.); Fish Creek, Buffalo, Erie Co. (U. S. N. M.); Stony Island, Jefferson Co. (U. S. N. M.). Massachusets: Pontoosuc Lake, Lanesborough, Berkshire Co. (M. C. Z.); Onota Lake, Goodrich Pond and Housatonic River, Pittsfield, Berkshire Co. (M. C. Z.); East Washacum Pond, Sterling, Worrester Co. (M. C. Z.); Blackstone River, Uxbridge, Worcester Co. (M. C. Z.); Lake Boone, Stow, Middlesex Co. (Boston Soc. Nat. Hist.); Walden Pond, Concord, Middlesex Co. (M. C. Z.). New Hampshrne: Lake Winnepesaukee (U. S. N. M.).

Cambarus immunis, taken as a whole, has an enormous range, as a common species, through the western states, from northern Ohio, through Indiana, 
Illinois, Michigan, Wisconsin, Minnesota, Iowa, Missouli, Kansas and Nebraska, into Colorado and Wyoming. ${ }^{1}$ To the eastward of Lcorain Comnty, Ohio, it has hitherto been lecorded from only two localities, both in the state of New York: in $1891 \mathrm{Mr}$. Gerrit Fmith Miller, Jr., brought me three specimens which he found in July of that year in a small stream flowing into Oneida Lake; these were recorded by me in 1898 (Proc. U. S. Nat. Mus., 20, p. 65t); in 1906 Dr. Ortmamn (Mem. Carnegie Mus., 2, p. 467) called attention to specimens in the New York State Museum which had been taken by Mr. F. C. Paumier in Rensselaer Lake, Rensselaer Co., N. Y. I can now add to the New York stations for this species the following:- pond near the mouth of Cattaraugus Creek, and silver Creek, Chantauqua Co. (U. S. N. M. Nos. 22,417, 22,40S); Fish Creek, Buffalo, Erie Co. (U. S. N. M. No. 22,418); and Stony Island, at the eastern end of Lake Ontario, Jefferson Co. (U. S. N. M. No. 22,409).

My first knowledge of this species as an inhabitant of Massachusetts was obtained when I was walking across the mud-flats at the upper end of Pontoosuc Lake on the 11 th of November, 1899. The numerous mud-towers or "chimneys" here rising above the level of the flat at once betrayed the abode of some kind of burrowing crayfish. Although the soil was then frozen so as to make exploration difficult, I satisfied myself that the builders of the little mudtowers had withdrawn to their brumal retreats in the deeper waters of the Lake, learing behind them only one dead companion, a first-form male $C$. immunis spinirostris (M. C. Z. No. 6,687). Here the matter rested until, during a risit to Berkshire in 1911, I ascertained that this crayfish was abundant on the 12th of August among the water-reeds at the head of Pontoosuc Lake. Two days later I searched for it at the northern end of Onota Lake in Pittsfield and again found it in altogether similar surroundings, albeit in much smaller numbers than in the neighbouring Pontoosuc or Lanesborough Pond.

On the 15th of Jume, 1912, I again collected this crayfish at the outlet of Goodrich's Pond and in the Housatonic River just above Pomeroy's Mills, in Pittsfield.

These specimens from Berkshire Co., Mass, agree in most respects with the types of $C$. immunis spinirostris, which were collected in Obion County, Teunessee. The rostrum in the Missachusetts examples tapers a little more between the base and the ante-apical teeth and, the antemal seales are a little shorter in proportion to the length of the rostrum. Compared with the typical

\footnotetext{
"There are two specimens of $C$. immunis, or f. Il. and of, in the IT. N. National Mlusemm, No. 3,257, labelled as coming from Orizaba, Mexico, through Professor Sumichrast. (Ace. 1806, Mar. 30, 1870).
} 
form of C. immunis from Illinois, C. immunis spinirostris differs in having a distinet spine or tooth on each side of the rostrum near the tip, more prominent post-orbital and branchiostegian spines and a shorter posterior section of the carapace in relation to the section in front of the cervical groove (the proportion being 1:2 or cven less in C. i. spinirostris); the claw, too is narrower, with proportionally longer and slenderer fingers.

In full-grown living specimens from Pontoosuc Lake (Plate 2, fig. 2) the dominant colour of the earapace is a rieh Vandyke brown shading into tawny olive on the sides; the cardine area is conspicuously marked off by being a much lighter colour,- tawny olive; the abdomen is beantifully mottled above with darker and lighter shades of tawny olive; the legs are olive-coloured.

In the young, $27 \mathrm{~mm}$. long, from the same locality (Plate 2, fig. 1), the brown of the adult is replaced by an olive-green which pervades the whole dorsal side of the creature and is delicately varied by mottling of olive-buff; the cardiac area is of the latter hue and is continued backward, throngh the whole length of the abdomen, as a broad median band; the appendages are delicate olive-green, changing to a pinkish tint at the tips of the elaws.

C. i. spinirestris was first described from Obion County, Tennessee; it has also been recorded from Omaha, Nebraska (Pearse), shawnee County, Kansas (Faxon), Douglas County, Kansas (Harris), Vigo County, Indiana (IV. P. Hay), Ottawa Co., Ohio (Pearse), and Long Point Creek, Canada (Pearse). As a matter of fact, specimens of $C$. immunis agreeing more or less closely with the form which I described as var. spinirostris are to be found pretty much thronghout the range of the species. I have seen such among material collected in Nebraska, Kansas, Missouri, Michigan, Illinois, Indiana, Ohio, and New York. I am therefore disposed to regard it as a variety rather than a true geographical race or subspecies, although it is true that all of the Massachusetts specimens possess the characters of spinirostris.

When Cambarus immunis was first diseovered in Berkshire County, Mass., it had been reeorded from only one place (Oneida Lake, N. Y.) east of Lorain County, Ohio, and in the State of Ohio it had been recorded from but three localities - Huron River at Huron, Eric County (Osburn and Williamson, 6th Amm. Rept. Ohio State Lead., 189S, p. 11), Sandusky, Erie County (Faxon, Proc. U. S. Nat. Mus., 1898, 20, 1. 654), and Lake Erie, Lorain Co. (Osburn and Williamson, l. c.). I was therefore formerly inclined to think that its presence in Berkshire County, Mass., was due to artifieial introduction, like the Cambarus affinis in the ponds of Essex County, Mass.; but I have now before me speeimens from 
along the Ohio slore of Lake Erie from Lucas County, through Ottawa County. to Erie and Lorain Counties, from the New Tork borders of the same Take in Chautauqua and Erie Counties, from the eastern end of Lake Ontario and from Lake Oneida; while Ortmann's discovery of the specimens in the Albany MIseum from Renssalaer County, N. Y., extends the eastward distribution of this crayfish up to Berkshire County, Mass. In the light of all the evidence now collected it seems to me possible, if not probable, that Berlsshire county is the eastern limit of the natural distribution of this species and that the discontinuit $y^{\prime}$ results from imperfect exploration of the waters of New York State. It slould be noted however, for what it is worth, that the Berkshire countrymen whom I have questioned believe the crayfishes are a comparatively late addition to the fauna of the Lakes.

However this may be, there can be no reasonable doubt that the presence of this crayfish in Worcester and Middlesex Comnties, Mass., and in Lake Winnepesaukee, N. H., is the result of artificial transference at a comparatively recent date. The first time this animal was found in Talden Pond, Concord, Midullesex County, Mass., so far as I can learn, was in the summer of 1909 , when two or more were captured, as I am told by Mr. Reginald Heber Howe, Jr, of the Middlesex School, Concord. In $1910 \mathrm{Mr}$. Howe sent me a fine specimen, a male about $3 \frac{3}{8}$ inches long, which had been taken in the Pond, and in early October, 1911, the Rer. Smith Owen Dexter and Mr. H. Richardson of Concord secured two specimens by a long search under the stones on the edge of Walden. Mr. Dexter's specimen, taken from the Pond the 9th of October, whon ahout $1 \frac{1}{2}$ inches long, lived in my aqnarium until April 6, 1912, casting its shell twice, on February 20 and March 19, and attaining a length of $1 \frac{3}{4}$ inches. On the 14 th of June, 1912, Mr. Dexter collected four specinens, ranging from $2 \frac{1}{2}$ to $4 \frac{1}{2}$ inches in length, from the borders of the Pond, and still more during the following month. On the 24 th of July, 1912, Mr. Ir. F. Clipp and I got six speciniens there.

I bave been told by citizens of Coneord that two men who fished in Milden Pond about ten years ago (c. 1903), wsing crayfishes for bait, threw their surplus bait into the Pond and thus unwittingly stocked it with these croutures.

Walden Pond is apparently a most uneongenial abode for Camburus immunis, being clear as a well and almost clestitute of regetable growth. The farourite haunts of this species are rather muddy waters stocked with a rank growth of pond weeds.

In 1913 specimens of this erayfish were collected in Boone l'ond, stow, 
Middlesex County, Mass., by Professor G. H. Barton. Boone Pond drains into the Assabet River. Walden Pond has no visible inlet or outlet.

Dr. D. L. Belding, of the Mass. Fish Commision, collected several specimens in East Washacum Pond, Sterling, Woreester Co., Mass. (Nashua River drainage), Oct. 10, 1912; Mr. W. F. Clapp found many in the Blackstone River, at Uxbridge, Woreester County, Mass., Sept. 29, 1913, and there is a specimen in the United States National Museum collected in 1913 in Lake Winnepesaukee, N. H.

In colour as well as in all other characters the Walden Pond and Blackstone River specimens agree perfectly with those from Berkshire County. Those from Boone Pond, Sterling, and Iake Wimnepesankee I have seen only after they had been immersed in alcohol and lost their colour; in other respects they too are conformable to the Berkshire County variety, $i . e ., C . i$ spinirostris.

\section{Cambarus validus, sp., nov.}

Plate 7, Fig. 3, 4, s; Plate 13, Fig. 1.

Male, form 1.- Similar to C. immunis Hag., but differs as follows:- the rostrum is relatively narrower, less tapering from the base to the lateral angles at the proximal end of the acumen, its margins are more distinetly raised so that the upper surface of the rostrum appears to be more deeply hollowed out. The foveola at the base of the rostrum in C. immunis is scarcely evident in C. validus. The chela is very much larger, more powerful and of a different form from that of C. immunis; the immovable finger is curved strongly outward at the hase, giving a convex outline to the external margin of the hand; the movable finger is furnished with a double row of tubereles running along its external margin, while the inner margin is not exeised at the base and is armed with a row of eight or nine round bead-like tubereles; the chela is as long as the carapace, and broad and inflated. The lower face of the carpus is furnished with only a rudimentary, blunt, median spine or tuberele. The sub-orbital angle is less prominent, the posterior wall of the orbit forming a perpendicular straight line. The anterior process of the epistome is much broader, with the anterior end truneated but not notehed. In other regards, including the form of the sexual appendinges it agrees with C. immunis. The rostrun is devoid of lateral teeth or spines, like the typical form of $C$. immunis.

Length, $68 \mathrm{~mm}$; ; length of carapace, $33.5 \mathrm{~mm}$.; length from tip of rostrum 
to cervical groove, $22 \mathrm{~mm}$.; length of chcla, $35 \mathrm{~mm}$; breadth of chela, $15 \mathrm{~mm}$.; length of dactylus, $21.5 \mathrm{~m} 1 \mathrm{~m}$.

Huntsrille, Madison Co., Mabana. One male, form I. M. C. Z.. No.301.

This specimen was considered to be $C$. immunis by Hagen, is mentioned by him on page 72 of his Monograph, and its chela is probably the one figured by him on Pl. VIII, fig. b. Compare my "Revision of the Istacidae," p. 100.

six specinens in the U. .. National Museum, three of which are males of the second form, and three females (No. 23,092) collected by Mr. J. E. Benediet at Nashrille, Temnessee, in May, 1897, without much doubt are conspecific with the type specimen of $C$. validus. Is they are younger than the type specimen, and as the first form of the male is not represented among them, the peculiarities of the species are not so well pronounced. The chelae are proportionally smaller and the curve of the immobile finger is less. This finger, as in the type speeimen and in $C$. immunis, is heavily bearded within at the base. The gonopods of the males are similar to those of second-form males of $C$. immunis, but less strongly curved; indeed the curve of the stem of the organ is no greater than it is in $C$. virilis, but the bhunt reeurved tips are subequal as in C. immunis; in other words the shape of the second form male organ is the same as in C.alabamensis. The annulus ventralis of the female is virtually the same as in $C$. immunis.

\section{Cambarus mississippiensis Faxon.}

New locality:- Agricultural College, Oktibbeha Co., Mississippi (U. S. N. M.).

\section{Cambarus lancifer Hagen.}

A female specimen, collected by Robert Kemnieott at Cairo, Ill., is in the U.S. National Muscum. The few specimens heret of ore known have come from Root Pond, Miss., Vicksburg, Miss., and the St. Francis River at Greenway and Big Bay, Clay Co., Ark.

\section{CAMBarus bartonil (Fabricius).}

Neu localities:- Manne: Little Madawoska River, a tributary of Aroostook River at New Sweden, Aroostook Co. (MI. C. 'L.); brook tributary to Iroostook River at Caribon, lroostook Co. (Coll. W. P. Hay). NEw Yonk: Sehoharie Creek, Catskill Mts., Green Co. alt. 2,000 ft. (U. S. N. M.); Little 
Simonds's Pond, Franklin ('o. (M. C . Z.); Three-Mile C'reek, Oswego, Oswego (o. U. A. N.M.). Trrania: Broad Run and Gap Run, Fauquier Co. (U. S. N. M.); Orkney springs, shenandoah Co. (U. S. N. M.); Stony Man Mt., 3000 ft., Madison (O. (U. S. N. M.); Praks of Otter, $2600 \mathrm{ft}$., Bedford Co. (U.S. N. M.). W West Thania: West Branch of Potomac Rivel, 5 miles west of Circleville, Pendleton Co. (U. S. N. M.); Rich Creek, Spanishburg, Mercer Co. (U. S. N. M.); Trubie's Run, 7 miles abore Buckhannon, Upshur Co. (T'. S. N. M.). North CArolina: Looking-Glass Creek, Transylvania Co., 3300 ft. (U. S. N. M.); near Montreat, Buncombe Co. (U. S. N. M.). TenNESSEE: 7 miles northwest of ('hattanooga, Hamilton Co. (U. S. N. M.); I ittle Rivel, a tributary of the 'Tennessee River at Cade's Cave (U. S. N. M.).

The Barton's Crayfish of Aroostook County in Northem Maine (of which there is a large collection in the United States National Museum from the Allegash River a little helow Chamberlain Lake, Churchill Lake, Eagle or Heron Lake, Conslake Throughfare, and Bean Lake, St. Francis River) is a small, clean form that in these clear, cool, northern waters shows a slight differentiation from the typical C. bartomii from the Middle States. The rostrum is more strongly decurved and the fingers are narower and more cylindrical and gape yidely at the base. The differences between this form and the type nevertheless do not seem to be great enough or constant enough to warrant a subspecific separation.

\section{Cambartes bartoni carinirostris Hay MS., subsp. nov.}

"Rostrum of medium length, very broad, nearly plane or slightly exeavated above and with a more or less distinct, median, longitudinal carina; acumen short, broad, with concare sides, its tip strongly upturned. Carapace with a spinulose angle belom the eye; branchiostegian spine obsolescent; areola of moderate width. Telson bi- or tri-spinose on each side. Antennac, when extended backward, leaching beyond the middle of the abdomen. Chelipeds stout and heary, chelac broad and strong, hearily punctate abore and below; inner margin of hand obscurely serrato-denticulate; fingers usually gaping at the base, strong dorn curved, pitted in lines, upper surface heavily ribbed. Otherwise essentially the same as typical $C$. bartomii.

"This form, which I regard as a well-marked subspecies, is in typical examples very like C. bartonii in general, hut different in the following regards:the carapace is a little more cylindrical, the rostrum broader and flatter, and 
always furnished near the tip with a median longitudinal earina. This carina is usually well defined and extends from near the acumen backward to albout the midlde of the broud flat surface of the fostrum; it is generally followed by an illdelined and very shallow foreola. In less typical specimens the carina is rednced to a very low, rounded, almost invisible elevation just between the latedal angles of the rostrum, or in some eases is wanting altogether; in such specimens the other chancters, - cylindrical carapace and hroad, flat rostrum, - will hardly be sufficient to separate them from other closely related subspecies.

"Type, U. S. Nat. Mus. No. 23,962. Crandy Creek, Oscoola, Randolph Co., IT. Va. IT. P. Hay coll., July 12, 1899. Mas, forma secunda.

"This erayfish is abundant in the main stream as well as in the tributaries of the Tygart's Valley and C'heat Rivers in Randolph County, West Virginia. I have collected typieal examples from the Tygart's Valley River at Bererly and near Elkins. It is most abundant, however, further east in the Cheat River basin, and Osceola may be regarded as approximately the centre of its distribution."- II. P. Hay MS.

C. b. carinirostris Hay is a slightly dilferentiated local form of C. bartonii found chiefly in the mountain streams of Randolph Co., W. Ta., the Cheat and Tygart's Talley River's and their tributaries. Outside of Randolph County, Mr. Hay secured a few specimens at Ilbright, Preston C'o., at Queens, Upshur Co., in the above-named river-basins. It is also probably to be found in the upper waters of the Kanawa River basin further to the south, since there are a few speeimens in the U. S. National Museum (Nos. 23,975, 28,605) from the Wrest Fork of the Greenbrier River, near Durbin, Pocahontas Co., and from Laurel Creek, in second Water Cave, near Greenville, Monroe Co., that are pretty characteristic examples of this race.

The median carina on the upper surface of the rostrum is a rather elusive character, in many individuals it is seareely if at all apparent. Such specmens retain, nevertheless the peculiar quadrungular outline of the rostrum, which is often a trifte broader at the base of the acumen than it is in the midclle. The areola is of moderate width and not so thickly pitted as it is in $C$. $b$. montanus.

The dimensions of Mr. Hay's type are as follows:-

Length, $63 \mathrm{~mm}$; length of earapace, 32 mm.; length of areola, $11 \frac{1}{2} 11 m$; width of areola, $2 \frac{1}{2} \mathrm{~mm}$.; width of rostrun between the eyes, $4 \mathrm{mmn}$; length of chela, $25 \mathrm{mmn}$; breadth of chela $11 \frac{1}{2} \mathrm{~mm}$.; length of dactylus, $16 \frac{1}{2} \mathrm{~mm}$. 


\section{CAMBARUS BARTONII MONTANTS (Girard).}

In looking over any extensive collection of Cambarus bartomii from the Alleghany Mountain region of Virginia and West Virginia one is struck by the tendency of the material before him to fall into two sets of forms, one characterized by a rather narrow areola, sparsely sown with impressed points or dots which incline to a serial arrangement in three or four longitudinal rows; while in the other set the areola is shorter and proportionally broader, and its field is thickly strewn with innumerable dots. On further examination it will be seen that the narrower areola usually goes with a shorter and broader rostrum, a more depressed and oval carapare and a narrower antennal seale. These two forms are often found in the same loeality and with these alone in view one might be justified in deeming them two well-differentiated species, but it soon becomes clear that in other places specimens are found that combine in a most perplexing fashion the features of our two supposed species.

The second of the two forms above noticed, the one with the shorter and broader and more thickly punctate areola and longer rostrum is the one too curtly diagnosed by Girard under the name of Cambarus montanus.

Ginard's deseription of C. montamus is as follows:- "Antennx more elongated and more filiform than in C. Bartonii. Rostrum intermediate in shape between the latter and $C$. carolimus, being proportionally longer than in C. Bartomii and shorter and less tapering than in C. carolinus. Dorsal sutures of the carapace more apart than in both of the latter species.

"Localitics. - Within the Alleghany ranges in Virginia and Maryland: tributaries of James River in Rockbridge Co. (Va.); Shenandoah River in Clarke Co. ( $\mathrm{Va}$. ), and Cumbertand (Md.) of the hydrographical basin of the Potomac; Sulphur Spring, Greenbrier River, an affluent of the Kenhawa River (Va.) [now W. Va.] of the Ohio basin."

When Dr. Hagen was preparing his Monograph of the North American Astacidae in 1868, he had the opportunity to examine one of Girard's types of C. montamus from Greenbrier River, W. Va., sent to him by Wm. Stimpson who then had the types from the Smithsonian Institute in Chicago, where in 1871 they were most unfortunately destroyed by the disastrous conflagration of that year.

Sixteen years later, while I was revising the Astacidae, I had the advantage of close personal intercourse with Dr. Hagen and free use of his notes and memoranda. The identity of Girard's Cambarus montanus is thus assured by an umbroken tradition. Neither Dr. Hagen nor myself in my earlier publications estcemed this form worthy of even a subspecific name, although its characters 
were pointed out in my Revision, p. 64. It may be well in our present more advanced knowledge of the (C. barlomii group to recognize $r$. montrunus as a geographieal race or subspecies of $C$. bartonii.

In the collection of the leademy of Natural siciences of Philadelphia there is a young nale, labelled "James River, Va., C. montumus." which is rery prohably a eotype or paratype of Cirard's Cambanus montemus. With regard to this and other quasi types of Girard's species in the Philadelphia Leademy, the reader is referred to Hagen's Monograph, p. 7, and ny Rerision, p. 11.

I have examined specimens of $C$. bartonii montanus, nearly ol quite typical, from the following loealities:- Transia: Wytherille, Wy the Co. (U. .. N. M., No. 13,966, M. C. Z., No. 3,S3S); Rocky Giap, Bland Co. (U. S. N. M., No. 2S,568.) West Virginia: Horsepen Creek, [Mingo Co.?] (U.S. N. M. No. 28,55̃5); Madam Creek, tributary of New River, opposite Hinton, Summers Co. (U. S: N. M., No. 28,556, M. C. Z., No. 7,398); Bergen's springs, 12 miles above Hinton (U. S. N. M., No. 2S,566); Delashneet Creek, Kegley, Mercer Co. (U. s. N. M., No. 28,610); Bluestone River, just abore its mouth, Mereer Co. (U. .. N. M., No. 28,570); mouth of Delashneet Creek, Bluestone River, Mercer Co. (U. S. N. M., No. 25,565); Bluestone River, Abb's Valley (U. S. N. M., No. 28,569); East River, Mercer Co. (U.S. N. M.); Rich Creek, Spanishburg, Mercer Co. (U. S. N. M.); Barrenche Creek, Perrysuille, McDowell Co. (U. S. N. MI., No. 25,573); War Creek, MeDowell Co. (U. S. N. M., Nos. 28,56t, 28,580); Guyandotte River, Baileysville, Wyoming Co. (U. S. N. MI., Nos. 2S, 562, 28,578, $280^{7}$ ).

Isolated localities from which I have seen specimens of $C$. burlonii very closely resembling the form montames in the breadth and punctation of the areola are: Alum Creek, Franklin Co., Ohio, R. C. Osburn and E. B. Williamson (U.S. N. M., No. 22,351), Cincinnati, Ohio (M. C. Z., No. 28S), creek at Knoxville, Tenn., Walter Faxon (M. C. Z., No. 3,47T). From Cogar's Mill, Elk River, Kanawha Co., IT. Ya., I have seen an interesting lot of speeimens that combine the characters of C. b. montamus and C.b. longulus, the rostrum and chela of montanus going with the reduced sub-orbital angle of longulus. These specimens are in the. U. S. National Museum, No. 23,990, and in the Museum of Comparative Zoölogy, No. 7,401.

\section{Cambarus bartonit robustus (Girard).}

Plate 3.

From Cambarus bartonii montanus the pasage is easy to ( $C$. b. robustus, in which form the rostrum is longer and more tapering, the areola rather longer and narrower and the outer margin of the liand more costate, an emphatic de- 
presion runing along the upper and lower faces of the immohile finger. In the Tnited states National Musem there ane many specincns from West Fork of Circenbrier River, MT. Ya. (No. 23,977, 23,978) and from Crane ('reek, WT. Ya., which are rery nearly typical examples of ( $r$. b. robushus. 'They differ slightly, it is true, from more northern specimens in having a little broader areola and less pronouncel impressions upon the immobile finger. In these regards they show an approach to $(.6$. montanus, from which the form robustus is probably derived.

Sperimens collected at Wytherille, Wythe Co., Ta. (U. S. N. M., No. 13,966, M. C. Z., No. 3,838) which were referral to C. b. robustus by me in 1890 (Proc. U. S. Nat. Mus., 12, 622) are in reality C. b. montanus.

Examples from Fredericksburg, Spotsylvania Co., Vir., were formerly referred to C. robustus by Hagen in his Monoglaph, p. So, and by myself in $11 y$ Rerision, 1. 61, 67, but they are not typical examples of C. robustus. These specimens (M. C. Z., Nus. 3,615, 3,797) are in many ways like to C.acuminulus in the rostrum which is longer and more tapering than in robustus, in the relatively short postcrior section of the carapace, greater width of the areola, and the highly dereloped spines at the base of the antennal seales, on the carpus, and on the merus. The lateral spine of the carapace is distinetly developed on almost all of the Fredericksburg specimens. I similar form is found at Raleigh, N. C. (U. S. N. M. No. 22,355).

After eliminating the specimens which lave been wrongly identified with C. robustus, the distribution of the latter race, in its true form, is restricted, as far as known, to the following regions:- OnTario: Toronto, Meston. MichiIGAN: Mayne, Mashtenaw, Oaklind, Sanilac, Huron, Oscoda, C'awford, Mleona and Ionia Counties. Онто: Knox, Lorain, Cuyahoga, and Ishtabula Counties. Now York: Chautanqua, Genesec, Mllegany, Monroc, Wayne, Tompkins, Oswego, Madison, Jefferson, st. Lawrence, Herkiner and Hamilton Counties. Pennstutanda: Eric, Crawford, Warren, MeKean, and Allegheny Countics (St. Lawrence and Upper Ohio drainage). West Traginld: West Fork of Cireenbricr River and Crane Creek.

Cambarus bartonii robustus is a sombre-coloured crayfish in life (Plate 3 ), the dominant color of the upper surface being a dusky olive tone, nearly uniform and little relieved by the inconspicuously red-tipped fingers of the large claw. The ambulatory appendages have a somewhat bluish cast, and the rentral surface of the creature tends to a dull whitish tint. After the animal is placed in alcohol, a large, bright red, quadrangular patch presently appears on the branchiostegites behind the cervical groove, denoting that part of the shell which 
is most susceptible to the action of the lirquid. After some hours the red enlour extends over the whole branchial region and for a time is sharply defined from the median areola and the other parts of the body, which still retain the dusky colour of the living animal. These striking colour-patterns resulting from recent inmersion in alcohol might easily be mistaken for natural life colours by one who had not witnessed the change, and it suggests the probability that some writers have been misled into deseribing such colours as those of the living animal. Randall, for instance, in the Journal of the Acadeny of Natural Fciences of Philadelphia, 8, p. 138, Pl. 7, describes and figures Astacus oregunus $(=4$. leniusculus Dana?) as having a red spot on each side of the carapace, quite similar to the red spot which temporarily shows in Cambarus b. robustus recently immersed in alcohol. So, too, the whitish or lemon-yellow spot on the branchiostegites of Parastacus bimaculatus Philippi (Inales Universidad Chile, 87, p. 378), which is probably the same species that I deseribed under the name Parastacus agassizii ( $c f$. the colour description of this species by Plof. Carlos E. Porter in Revista Chilena de Historia Natural, 8, p. 258, pl. 9, fig. b) may possibly be the result of the action of alcohol on freshly killed specimens.

\section{Cambarus bartoni longulus (Girard).}

Ncw localities:- West Viranda: West Fork of Greenbrier River, near Durbin, Pocahontas Co. (U.S. N. M., No. 23,992); Bluestone Rivel, Ablo's Talley (U. S. N. M., No. 28,618).

In normal specimens of this subspecies the sub-orbital angle is hardly if at all prominent. The individuals which 1 mentioned in Proc. T. .. X. MI., 12, p. 623 , as having the orbit sharply defined below by a prominent angle may prove to be, I suspect, C. bartonii longirostris. This form is not very well known as yet, and I have reason to think that it acquires with maturity a claw very much like that of $C$. bartonii longulus. The character of the sub-orbital margin of the carapace seems to be very constant within the limits of a good subspecies, and it may prove to be the really diagnostic feature for separating $C$. b. longulus and C. b. longirostris.

Cambarus bartonit veteranus, subsp. nov.

Plate 13, Fijir. 2.

Rostrum long, without lateral teeth, margins elevated, strongly convergent, acumen triangular, terminating in an upturned corneous tooth. Intero-lateral 
margins of the carapace destitute of any marked angle below the eye. A small spine on each side of the carapace on the posterior edge of the cervical groove. Areola long and broad, $\frac{1}{4}$ as broad as long, thiekly strewn with impressed dots. Anterior process of the cpistome triangular, truncated anteriorly in old individuals. Chelae large, flattened, internal border furnished with a row of low tubercles, with another row of obsoleseent ones rumning along beside them. The outer margin of the chela is ridged, on account of a marked longitudinal depression which runs along the distal part of the palm and the proxinal part of the immobile finger. The fingers are long, heavily pitted, meeting only at their tips, leaving a wide gape between them. The carpus is amed with an intemal median spine, and a very small internal posterior spine; below it is furnished with the usual anterior median spine and a minute spinous tubercle between it and the internal median spine. The lower face of the merus is armed with a row of spines along its internal margin and an incomplete row on its external margin made up of about three at the distal end of the joint.

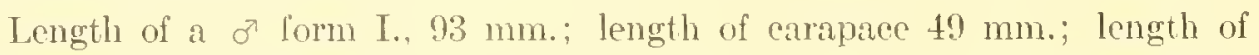
areola, $17 \mathrm{~mm}$; width of areola, $4 \mathrm{~mm}$; length of chela, $67 \mathrm{~mm}$; width of chela, $26 \frac{1}{2} \mathrm{~mm}$; ; length of dactylus, $45 \mathrm{~mm}$.

Type locality, Indian Creek, Baileysville, Wyoning Co., W. Ta.

Two males of the first form, sixteen males of the second form and seven females were collected by Mr. W. P. Hay at this place on the 16th of August, 1900. They are in the collection of the U. S. National Museum, Nos. 25,020, $28,609,44,712$ (type).

There are also in the National Museum one male of the second form and two females (No. 28,619) from Crane Creek, IV. Va., collected together with C.b. mobustus on the sth of August, 1900 , and one male of the first form from the Elk River, Cogar's Mills, W. Ta.

This peculiar form of $C$. bartonii rescmbles $C . b$. longulus in the form of the rostrum, the wide gape of the fingers of the large elaw, and in the absence of a sub-orbital angle. In otheir respects it is very different from longulus, especially in the shape of the chela which is strongly depressed, with deep longitudinal furrows at the base of the immovable finger, both above and below, as in $C . b$. robustus, while in $C . b$. longulus the fingers are cylindrical and bearded within at the base. The characteristic gape of the fingers is not present in regenerated claws, which are furnished with very long straight fingers whose cutting edges are straight and meet together throughout their whole length. 
Cambarus baltonit asperimanus, subsp. nov.

Even as these pages are going to press, two speeinens of a peculiar, new race of $C$. bartonii are sent to me from the U. . S. Nitional Muscum,- males of the first form, eolleeted by Mesis. P. C. Standley and H. C. IBolman in Flat Creek, near Montreat, Buncombe Co., N. C., Sept. 1, 1913. C. bartonii bartonii was also collected at the same time and place. The new form is eonspieuously different from any previously known race of ('. bartonii in haring seattered coarse setae upon the chelae, which are moreover deeply and coarsely pitted, with a tendeney toward corrugation: the inner horder of the propodus is furnished with a cristiform low of from five to seren teeth; the dorsal face of the carapace is extremely smooth and shows hardly a trace of the eustomary pits or impressed dots except a row along the margin of the rostrum; even on the areola the dots are searcely risible without high magnification: finally, the anterior process of the epistoma is broadly truncate in front.

Such are the diagnostic eharaeters of this sub-species, which in other regards agrees pretty closely with typieal C. bartonii. The hooks of the third segment of the third pair of legs are acute and attenuated at the tip.

Length, 54 mun., carapace, $27 \mathrm{~mm}$; cluela, 19 mm. Type, U. .. N. М., No. 47,375 .

\section{Cambarus bartonil acumnatus Faxon.}

Cambarus acuminalus FAxon, Proc. Amer. Acull, 1SSt, 20, p. 113.

New localities:- Marrund: Torthwest Branch, Hyattsville, Prince George's Co. (U.S. N. M.); Indian C'reek, Beltsville Prinee George's Co. (U. S. N. M.): North Carolina: Halifax, Halifax ('o. (U. ... N. M.).

As noted above under Crmbarus bartoniirobustus, speeimens from Fredericksburg, Va. (M. C. Z., Nos. 3,015, 3,797) approach elosely to the form acuminatus and seem to exemplify a transition from robustus to acuminatus.

\section{Cambartes bartonit laEvis, sulsp, not.}

This form of C. bartonii differs from the typieal race in having the carapace smoother and less eonspienously punctated, the posterior section proportionately longer, being equal in length to the distance from the cervical groove to the root of the eye-stalks; this lengthening of the hind section of the carapace involves a long areola which in also not nucely relativaly but also absolutely 
narrower than in the typical C. bartonii; the areola is so narrow as to allow barely room for two closely approximated longitudinal rows of dots; the rostrum is a little longer than in C. bartonii, with more convergent margins and a longer acumen; the upper or superior border of the hand and movable finger are more distinctly tuberenlate; the fingers are shorter, stronger, and more heavily ribbed, and the outer border" of the immobile one is more heavily and coarsely punctate. The posterior intemal spine of the carpus is obsolete; the anterior process of the epistoma is more broally triangular.

Type specimen, M. C. Z., No. 3,S12, W. S. Blatchley, Bloomington, Ind. o, form II. Measurements:- Length, $67 \mathrm{~mm}$., length of carapace, $33 \mathrm{~mm}$., length of areola, $14 \mathrm{~mm}$., breadth of areola at middle, $1 \mathrm{~mm}$., length of right chela, $24 \mathrm{~mm}$., length of right dactylus, $16 \mathrm{~mm}$.

Other localities:- Fall Creek, Indianapolis, Ind. (M. C. Z., No. 3,796), New Albany, Ind. (M. C. Z., No. 3,61S), Irvington, Ind. (U. S. N. M., Nos. 19,738, 22,204), May's Cave, Monroe Co., Ind. (U. S. N. M., No. 19,740).

The peculiarities of this crayfish, which appears to be a common form in the State of Indiana, were first pointed ont in my Notes on North American Crayfishes, Proc. U. S. Nat. Nus., 1890, 12, p. 622. It has been described and figured, as C. burtonii, by Mr. IV. P. Hay in the Twentieth Amm. Rep. of the Department of Geology and Natural Resources of Indiana, 1S96, p. 437-489. The features which distinguish it from the typical form of $C$. bartonii are so pronounced as to render it necessary to mark it as a subspecies of $C$. bartonii if not as a ralid species. In the great relative length of the posterior section of the carapace it resembles C. bartonii tencbrosus Hay from the Mammoth Cave of Kentucky.

According to letters which I received from Dr. John Sloan of New Albany, Ind., in the year 1883 , this crayfish was always found hy him in that region to be a, denizen of standing ponds and still water, being replaced by $C$. sloanii in the running streams. On the contrary, both Mr. W. P. Hay (l. c., p. 489) and Mr. A. M. Banta (The Fauna of Mayfiekl's Cave, Carnegie Inst. of Washington, Publ. No. 67, Sept. 1907, p. 73-75) aver that it is most commonly found in springs and small streams of elear ruming water where it seeks concealment under stones or in shallow burrows.

Messis. Hay and Banta have found this form a frequent inhabitant of the caves of southem Indiana in company with the blind species, C. pellucidus. Those that dwell in the cares appear to attain a greater size than those in the surface waters, specimens in the Mitchell Caves, Lawrence Co., often exceeding 
$100 \mathrm{~mm}$. in length accorling to Banta, while those from the outside do not exceed $84 \mathrm{~mm}$. A series of fifty-eight specinens from the outside waters compared with a series of six specimens from Mayfielel's Cave, Monroe Co., by Mr. Banta revealed the fact that the antennae of the cure speeimens averaged $11.89 \mathrm{p} . \mathrm{c}$. longer than the antennac of specimens taken outside the cuves in the immediate vicinity. The cave scries was also lighter-coluured than the series from above ground.

\section{Cambarus graysont, sp, not.}

Cephalothorax rohust, posterior section high, fiattened on the hack and compressed laterally so that the sides are nearly vertical, giving to the whole seetion a subquadrangular aspect; shell densely punctated on the dorsal face, gramulated on the lateral surfaces; distance from the tip of the rostrum to the cervical groove one and one half times the length from the cervical groove to the posterior end of the carapace; there are no lateral spines upon the carapace and only the rudiments of the branchiostegal spines: the areola is narrow (1.;) mm. broad at the middlo in a specimen measuring $21 \mathrm{~mm}$. from the cervical groove to the posterior border of the carapace) with but two rows of dots along the narrow part of its course; rostrum short, margins slightly convergent, middle exeavated, acumen short, upturned at the tip, without lateral spines or tecth; post-orbital ridges low, without spines: sub-orbital angles well marked but blunt.

Abdomen as long as the cephalothorax, smooth, pleural angles rounded.

Chelipeds short in proportion to the body; merus short, with low tubereles near the distal end of the superior margin and spines biserially antanged on the lower face; earpus decply furmowed along the upper fare, armed with al prominent median internal acute thorn or spine, one or two small tubereles in place of a median posterior spine: an inferior molian spine, with sometimes a small tuherele between it and the interior median spine completes the armature of the carpus; the ehela is short. broad and triangular, articulated with the earpus in sucle a way as to assume a vertical position when flexed and to form with its fellow a shich or operculum appressed to the front of the body; this conformation of the chelae is a sure token of the hurrowing habits of this suecies; the inner (or superior) margin of the palm, is very short, with a marginal mow of five or six low tubercles; immediately within this row (which forms a serrate odge to the hand) is another row of similar though smaller tubereles, with restiges of a few more irregularly disposed near the articulation of the dactylus: the fingers 
are rather short, strongly curred downward or inward, not conspicuously ribbed, their prehensile margins armed with rounded teeth, the free edge of the dactylus furnished with low, ciliated, squamous tubercles.

Antemal scale small, narrow. Anterior process of the cpistome broad, truncate, anterior border concave, with a median tooth. Sexual organs of male and female similar to those of $C$. bartonii.

Dimensions of a female specimen:- length, $113 \mathrm{~mm}$. length of cephalothorax, $54 \mathrm{~mm}$., breadth, $29 \mathrm{~mm}$, height of do., $21 \mathrm{~mm}$.; length of areola, $21 \mathrm{~mm}$., breadth of areola, $1.5 \mathrm{~mm}$.; length of eheliped, $75 \mathrm{~mm}$.; merus, $21 \mathrm{~mm}$.; length of chela, $39 \mathrm{~mm}$; ; breadth of chela, $19 \mathrm{~mm}$.; length of dactylus, $24 \mathrm{~mm}$.

Bear Creek, a tributary of Green River, (irayson springs, Grayson Co., Ky., Oet. 24, 1874, F. W. Putnam coll. 1 male of the second form, 3 females. M. C. Z., No. 3,593.

This species is nearly related to C. ortmanni. Its form, like that of $C$. ortmanni, denotes a species of fossorial habits, but not so preëminently addicted to subterranean life as the species of the $C$. diogenes group, in which the cephalothorax suffers a greater lateral compression. Compared with C. ortmanni, C. gruysoni is more depressed dorsally, more heavily punctated, the areola is broader (as broad as in the typical form of $C$. latimanus) the metathorax somewhat shorter in proportion to the prothorax, the suborbital angle is much more salient, the anterior process of the epistoma is deeply emarginate in front, with a prominent spine at the bottom of the emargination, the internal carpal spine is acute even in old and large examples, and the tubereles of the inner (superior) margin of the hand are stronger and biserially disposed.

The specimens which form the types of $C$.graysoni were referred to $C$. bartonii in my Revision of the Astacidae, p. 61, 159, 169. The peculiarities of the chelipeds, however, show that they belong to a distinet species, allied to $C$. ortmanni and C. latimomus and forming together with these species a group eonnecting $C$. bartonii and its near allies with $C$. dioyenes and the nearly related preeminently burrowing forms.

\section{Cambarus ortmanni Williamson.}

Cambarus ortmani Williamson, 31st Ann. Rept. Department Geol. Indiana, 1906, 1907, p. 754-760, pl. 35.

Cambarus ortmanni, a burrowing species, was described by Mr. E. B. Williamson from specimens captured in Wells Co., Ind., in the Wabash River drainage near Bluffton. There has been a single female specimen from Cincinnati, O., 
however, in the Museum of Comparative Zoology since the early days of the Museum. This specimen, No. 243, was referred to C. burtonii by Dr. Hagen in his Monograph and entered into his computation of the rariability of the width of the areola of that species, on p. 7S. In my subsequent Revision of the Astacidae, in 1855, p. 64, I referred to this individual as possibly a peculiar species related to C. latimanus.

In the shape of the body and the narrow areola $C$. ortmanni bear's a close resemblance to $C$. latimanus striatus, but in the outline of the rostrum and the seulpture of the claws it betrays a closer resemblance to C. bartonii. It is without doubt an immediate offshoot of the latter, modified by fossorial habits; the narrow areola, broad, conical elaws, small antemnal scale, long, narow and quadrangular epistome, all denote this. It forms a passage from $C$. bartonii to $C$. latimanus on the one hand and on the other to the more eminently fossorial forms, C. carolimus, C. diogenes, ete.

\section{Cambarus latminus (Le Conte).}

There is a cotype, a dried male, in the Museum of Comparative Zoölogy, No. 3,378, aequired by exchange of types with the smithsonian Institution in 1561 ; another cotype, a dried female, is preserved in the collection of the Aeademy of Natural Sciences of Philadelphia. There are also in the Museum of Comparative Zoölogy, No. 236, preserved in aleohol, 3 males of the first form, 6 males of the second form, 3 females, and 7 young, collected in Athens, Ga., and sent to Professor Agassiz by LeConte in the 50's. These are essentially paratypes, and are of interest as fixing the type locality, Athens, Ga., which was not specified in Le Conte's original description of the speeies nor on the labels aceompanying the type specimens in Cambridge and Philadelphia.

Two males, dried, M. C. Z., No. 3,366, sent by Prof. Tewis R. Gibhes from South Carolina as C. bartonii, without precise locality, are the only specimens reported from South Carolina so far as I know.

A small young female from Milledgeville, Ga. (M. C. Z., No. 3,365) and another from Roswell, Ga. (MI. C. Z., No. 3,502) probably belong to this species.

Specimens from Blount Spring and Cullman, Ala. (U. S. N. M., No. 4,953, M. C. Z., No. 3,639) differ from the typical form in having a uarrower rostrum, and in specimens from Bridgeport, Ala, and Nickajack Cave, Lshland City, and Nashrille, Tenn., the divergenee from the type is so promomeed that Mr. W. P. Hay has deseribed them as a subspecies, C. latimanus striatus (Proc. U. A'. Nat. Mus., 1902, 25, p. 437; type locality, Nashville, Temu.). 
Mr. C. F. Baker has sent me a fine lot of C. latimanus from Auburn, Ala., among them speeinens that have attained a lengtl of four inches.

\section{Cambarus carolinus Erichson.}

This species was described in 1846 (Arch. Naturgesch., 12, 1, p. 96). Erichson's type, a male of the first form, is preserved in the Berlin Museum. It was collected hy Dr. Cabanis, who assured Dr. Hagen that all the erayfishes that he collected in the United States came from a rivulet in a plantation called Tiger Hall, near Greenville, S. C. I In 1902 Mr. W. P. Hay procured from Dr. Johann Thiele of Berlin a plotograph of the type specimen together with drawings of the right claw and first and second abdominal appendages. By means of this photograph and the drawings Mr. Hay identified the species with the crayfish which I described in 1884, from Cranberry Summit (now Terra Alta), Preston Co., W. Ta., mnder the anme of Camburus dubius (sce Hay, Proc. Biol. Soc. Washington, 15, March 5, 1902, p. 38.

By the courtesy of Mr. Hay I have before me Dr. Thicle's photograph and drawings of Erichson's type, and find that, although it nearly resembles C.dubius, yet it presents some different characters. The carpus is armed on its imner margin with two prominent, aeute spines; of these the larger, anterior one is the so-called internal median carpal spine; on the left cheliped the photograph reveals a tuberele just behind, and at a lower level than, the median spine. In $C$. dubius there is but one carpal spine, the internal median. Furthermore, the outer margin of the hand of C. carolinus, as shown in Dr. Thiele's drawing, is rounded off and lacks the subserrate ridge characteristic of $C$. dubius; in this regard the hand of $C$. corolimus appears to be like that of $C$. monongalensis Ortm.

No. 14,314, U. S. N. M., male, form I., "among the Cherokees, James Mooney," agrees closely with the pictures of Erichson's type, and may be considered a typical C. carolinus. In a notice of this specimen as $C$. dubius in 1890 (Proc. U. S. Nat. Mus., 12, p. 624), I erred in ascribing it to the Indian Territory. I am advised by Mr. Mooney that it was in reality obtained in Swain Co. or in Jackion Co., N. C., among the Eastern Cherokees,-- a remmant of the Nation which eluded deportation in 1838 and still elings to the old home in western North

\footnotetext{
${ }^{1}$ Mr. W. P. Hay (l'roc. Biol. Soe. Washington, 15, p. 35, 1902) has unfortunately given this locality as western North Cerolina, and has been followed in this error by Mr. J. A. Harris (Kansas Univ. sici. Bull., 19003, 2, p. s1, 112, 15!).
} 
Carolina. It thus appears that Mr. Mooney's crayfish came from a region not far remote from the type locality of $C$. carolinus.

In this specimen (U. S. N. M., No. 14,314), which displays the normal features of $C$. carolinus, as I beliere, the rostrum is narrower than in C. dubius and less quadrangular in outline; the anterior process of the epistoma is nuch broader and more triangular in outline, the sides converging much more betreen the base and the truncated anterior angle; the carpus is armed with a prominent, acute, internal median spine, immediately behind which and at a lit the lower level lies a very small spiny tubercle; posteriorly to this, not far from the inner articulation with the merus, lies another distinet spine, smaller than the internal median spine; the lower face of the carpus bears one tubercle about half-way between the internal median spine and the outer articulation with the propodus: the lower face of the merus shows the biserial arrangement of spines as in $C$. dubius, as many as five or six spines adoming the external edge of the segment: the distal segment of the outer branch of the last pair of abdominal appendages is shorter and broader (less oval in contour) than in C. dubius. The living color of this specimen, as is shown by a MS. note accompanying the specimen, was red, the color of $C$. dubius also.

A large number of specimens in the U. S. National Museum collected at various places in the southwestern part of West Virginia (Nos. 28,591-2S,596, 2S,598-28,600, Horsepen Creek, War Creek, Baileysville, Lashmeet, Barranche Creek), agreeing in most respects with the typical $C$. dubius from northern West Tirginia and Pennsylvania tend to develop the accessory carpal spines and tubercles of $C$. carolinus.

Three specimens (male, form I.) in the U. S. National Mureum, No. 22,356, from a tributary of Stone River twenty miles from Columbia in central Temnessee are interesting. They agree in most respects with $C^{\prime}$. c. dubius, but the rostrum is a little narrower, with more convergent margins, the rostral acumen is less abrupt, and the outer border of the hand is rounded off without much indication of serrature. In these regards the specimens agree with the typical carolinus; the carpus, however, is very smooth, hearing no spines except the internal median, as in C.c. dubius. The outer inferior row of spine: on the merus is present, though slightly developed. The branchio-cardiac lines are in eloser contact than in any other specimens of this species that I have seen, reducing the areola to a narrow line.

1 See Myths of the Cherokee, by James Mooney, Nineteenth Ann. Rem. Burean Amor. Ethnol. $1897-98,1900, \mathrm{p}, 30 \mathrm{~s}$. 
The closely related Blue or Monongahela Crayfish was first diseovered at Pittsburgh, Pa., in 1898, by Mr. E. B. Williamson. Specimens were sent to me in the month of Augut of that year, which appeared to me to be a local form of $C$. dubius, and they were recorded as such by Mr. Williamson in a paper on the Crayfish of Allegheny County, Pennsylyania (Ann. Carnegie Mus., 1901, 1, p. 11). Compared with the type of $(C$. dubius these specimens showed a narrower rostrum with less pronounced angles at the base of the acumen; the outer border of the hand was evenly rounded, not ridged, and destitute of the imperfect serrature seen in C. dubius, where this feature results from the regular row of transversely elongated marginal punctations giving to the margin a milled appearance; further, the earpus of the Pittsburgh form was armed with several aceessory spines and tubereles, besides the prominent internal median spine which is all the armature of the carpus in C. dubius.

In a paper on the Crawfishes of western Pennsylvania published in 1905 (Ann. Carnegie Mus., 3, No. 2) and in a more elaborate memoir which appeared at the close of the following year (The Crawfishes of the State of Pennsylyania, Mem. Carnegie Nus., 2, No. 10), Dr. A. E. Ortmann showed that the Blue Crayfish and $C$. dubius both lived in western Pennsylvania, that they oceupied different areas separated by the Chestnut Ridge, a range of hills on the west of the Allegheny Mountains, the Blue Crayfish (to which he gave the name Cambarus monongalensis) being found on the hills lying on the west of this range while $C$. dubius lived in the momntain region to the east of Chestmut Ridge, between it and the principal range of the Alfegheny Mountains. Dr. Ortmann also brought out clearly, as a result of extensive field study, the color-difference between the two forms, the dominant color of $C$. dubius being red, of $C$. monongalensis blue. The range of the latter form appears to be rather narrow, being restricted, as far as is shown by Dr. Ortmann's most interesting investigations, to Westmoreland, Allegheny, Beaver, Washington, Fayette and Green Counties, Pa., and Haneoek, Brooke, Ohio, Marshall and Monongalia Counties, W. Va., at altitudes ranging from 800 feet to 1200 feet above the sea-level.

Dr. Ortmann compared his speeimens of $C$. monongalensis with the northern race of $C$. carolinus, $i$. e., C. dubius Fax., and came to the conclusion that they represented a distinet species. But as appears from what has been said above, three of the characters which Ortmann thought were peculiar to C. monongalensis are also present in the southern, typical form of $C$. carolinus, viz., the narrower rostrum, non-serrated outer margin of the hand, and the presence of more than one spine on the inner side of the carpus. There are thus left but two features 
to separate $C$. monongalensis from $C$. carolimus, viz., the uniserial disposition of the spines on the lower face of the merus of the cheliped, and the colour.

So, with a broader overlook of the geographical variations of these interesting forms it woukd seem to be more logical to consider C. carnlimus Eriehs., C. dubius Fax. and C. monongalensis Ortm. as three geographical races, or subspecies of one species. The three subspecies may be distinguished by means of the subjoined key:-

Lower face of merus with only one row of spines developed. Colour, blue.

Lower face of merus with two rows of spines developed. Colour, red.

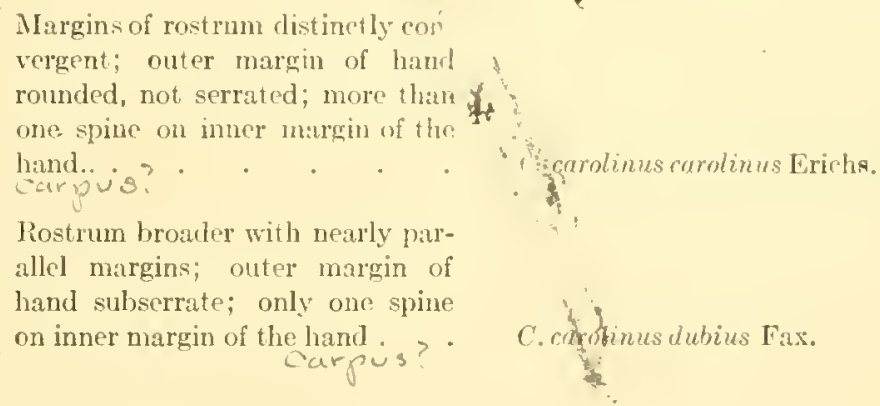

The geographical range of C.c. monongalensis, so far as it has been worked out by Dr. Ortmann, has been given above. More exploration is needed to elucidate the dispersal of the typical C.carolinus. The type locality is near Greenville, Greenville Co., S. C. The specimen in the U. S. National Museum, collected by James Mooney and described above, came from swain or Jackson Co., western North Carolina. Ortmann (Mem. Carnegie Mus., 2, p. 397) mentions some specimens in the Acadeny of Natural seiences of Philadelphia, collected by Prof. J. P. Moore at Blowing Rock, Watauga Co., N. C., which have a narrower rostrum than $C$. c. dubius, and are therefore probably $C . c$. carolinus.

Specimens collected by Mr. H. G. Hubbard at Penmington's Ciap, Lee Co., Va. (M. C. Z., No. 3,489) and by myself at Cumberland (iap, at the junction of the three states of Virginia, Kentucky and Tennessee (M. C. Z., No. 3,594) are too young to detemine subspecifically with assurance, but they appear to be C.c. dubius. The form spread over the southwestern parts of Mest Virginia, as has been pointed out (p. 397) is more or less intermediate between carolinus and dubius, while the pure C.c. dubius has been reported from Westmoreland, Fayette, and Somerset Cos., Pa., Carrett Co., Mck., and Preston, Tucher, and Mineral Cos., IT. Va. 


\section{Cantbarts diogenes Girard.}

New localities:- Maryland: Iaurel, Prince Georges Co. (U. S. N. M.). Tirginia: Dismal simamp (U. S. N. M.). North Carolina: Near Beaufort, Carteret Co. (Coll. W. P. Hay). Alabana: Auburn, Lee Co. (M. C. Z.). Mississtppi: Muldon, Monroe Co. (U.S. N. M.); Agricultural College, Oktibbeha Co. (T. S. N. M.). OHı: Toledo, Lucas Co. (U. S. N. M.). Indana: Near Milltown, (rawford Co. (U. A. N. M.); Lake Maxinkuekee, Malshall Co. (U.S. N. M.); White Co. (U. S. N. M.). Ilumnors: Wabash Co. (U. S. N. M.) ; Henderson Co. (U. S. N. M.); near Olney, Riehland Co. (U. S. N. M.). Iowa: Burlington, Des Momes Co. (U.S. N. M.). Michigan: Raisin River, Monroe, Momoe Co. (U.S. N. M.). Nebraska: Omaha, Douglas Co. (M. C. Z.); Creightom ('reek, south of Niobrara, Knox Co. (U.S. N. M). ColoRADO: Fort Collins, Loriner Co. (M. C. Z.).

Fnox Co., Indiana, given as a station for $C$. diogenes in my Revision of the Astacidae, page 71, should be transferred to C. argillicola, p. 77.

\section{Cambarts dogenes ludovicianus Faxoll.}

Ncu localitics:- Frierson, De Soto Co., La.; Rosedale, Bolivar C@o., Miss.; U. S. N. M.).

\section{Cambarus argillicola Faxon.}

Ncw localitics:- Olney, Richland Co., Ill. (U. S. N. M.); Frierson, De Soto Co., La., in bumows 15 inches deep, sumounted by low mud "chimneys" (U. N. N. M.).

\section{Cambarts uhleri Faxon.}

Mr. IV. P. Hay captured one specimen of this species near Beaufort, N. C., lug. 17, 1912. 'This specimen, a female, was taken from a hole in the bank of a pond on the soutli side of Adley's Creek, about fourteen miles north of Beaufort. On the other side of the sane creek, about a mile away, Mr. Hay collected three specimens of $C$. diogenes (also females) in holes on the edge of a swamp. The specimen of $C$. whleri differs from the type speeinens from Maryland but very slightly, the rostrum being a trifle more concave above, and the foveola at the base of the rostrum rather nore pronounced.

Uhler's Crayfish has heretofore been known only from the tidewater Ocean and Bay counties of eastern Maryland. 
Cambarus clyestús flay.

Proc. 1... Nat. Mus.. ()et. 11, 14!)!, 22, p. 12:, fig, 2.

The type specimen of this species, a female, U. N. Nat. Mus., No. 17:277, is the only one known. It was found by Mr. C. 1. Coleman, of the L. s. Biologieal Survey, in April, 1892, in a skiff at Bay st. Louis, Mist. Mr. Hay surmises that it belongs in the neighbourhood of C. cubensis; I should incline rather, on aceount of the structure of the annulus ventralis and the shape of the hody, to place it in $C$. bartonii group. 


\section{IIST OF THE DESCRIBED SPECIES OF CRAYFISHES (PARAS- TACIDAE AND ASTACIDAE). \\ $-19 / 4-$ \\ PARASTACIDAE.}

Astacopsis Huxley.

Astacorsin Hluxley, Proc. Zoöl. Soc. London, 1878, p. 7134.

1. Astacopsis franklinit.

Astacus franlitimii Gray, Eyre's Jounals of Expeditions of Discovery into Central Australia, 1845, 1, p. 409.

Type locality:- Tasmania.

2. AstaCOPSIS NOBILIS.

Astacoïdes nobitis Dana, Crustacea U. S. Expl. Exped., 1852, 1, p. 526.

Type locality:- New South Wales?

3. Astacopsis spiniFERA.

'Cancer sematus Shaw, Zoölogy of New Holland, 1794, pl. S, (nec Cancer serratus Forski̊l, 1775).

? Astacus australasiensis Milne Edwards, Hist. Nat. Crustacés, 1837, 2, p. 332. Type locality:- Sydney, Australia. Two colypes, Paris Mus.

? Astacus anstratiensis Erichson, Arch. Naturgesch., 1846, 12, 1, p. 94 (nom. emend.).

Astacoïdes spinifer Heller, Reise der Novara, Zool. Th., 2, pt. 3, Crust., 1865, p. 102.

Astacus amatus Martens, Inn. Mag. Nat. Hist., 1866, ser. 3, 17, p. 359. Type locality:- Muray River, Australia. Type, Berlin Mus.

?Astacopsis paramattensis Bate, Rept. Challenger, 24, Crust. Macrura, 1S8S, p. 202. Type locality:- Paramatta River, Sydney, Australia. Type, Brit. Mus., 1 \%.

?Astacopsis sydneyensis Bate, Rept. Challenger, 24, Crust. Macrura, 1888, 1. 204. Type locality:- Sydney, Australia. Type, Brit. Mus., 1 ㅇ.

Type locality:- Australia.

\section{Incertae Sedis.}

1. Astaropsis? tasmanicus.

Astacus tasmanicus Erichson, Arch. Naturgesch., 1846, 12, 1, p. 94.

Type locality:- Tasmania. Type, Berlin Mus., No. 1,579, 우 


\section{CHER IPS Erichson. \\ Cheraps Erichson, Arch. Naturgesch., 15ti, 12, 1, p. 101.}

1. Cheraps preissit.

Astacus (Cheraps) preissii Erichson, Arch. Naturgesch., 1816, 12, 1, p. 101.

?Astacoüdes plcbejus Hess, Arch. Naturgesch., 1S65, 31, 1, p. 164. Type locality:-Sydncy, Australia. Type, Göttingen Mus.

Type locality:- Southwestern Australia.

2. Cheraps bicarinatus.

Astacus bicarinatus Gray, Eyre's Joumals of Expeditions of Discovery into Central Australia, 1845, 1, p. 410.

Type locality:- Port Essington, North Australia.

3. Cheraps quadricarinatus.

Astacus quadricarinatus Martens, Monatsber. Akad. Wissensch. Berlin, 1868, p. 617.

Type locality:- Cape York, Australia. Typc, Berlin Mus., No. 2972.

4. Cheraps quinquecarinatus.

Astacus quinquecarinatus Gray, Eyre's Journals of Expeditions of Discovery into Central Australia, 1845, 1, p. 410.

Typc locality:- Western Australia, near Swan River.

\section{ENGAEUS Erichson. \\ ENrateus Erichson, Mreh. Naturgesch., 1st6, 12, 1, p. 102.}

1. Engaeus fossor.

Astacus (Engacus) fossor Erichson, Arch. Naturgesch., 1S $16,12,1$, p. 102.

Type locality:- Tasmania. Types, Berlin Miss., Nos. 1123, 1124.

2. Engaeus cunicularius.

Astacus (Engacus) cunicularius Erichson, Arch. Naturgesch., 1S46, 12, 1, p. 102 .

Engaeus cunicularis Haswell, Cat. Australian Stalk- and Sessile-eyed Crustacea, 1S82, p. 179. (Err.typograph.?)

Typc locality:- Tasmania. Type, Berlin Mus., No. 1122.

Paranephrops White.

Paranerhrops White, Gray's Zoöl. Miscell., June, IS12, p. 7!!.

1. Paranephrops planifrons.

Paranephrops planifrons White, Gray's Zoöl. Miscell., June, 1812, p. 79. 
ZParanephrops tenuicornis Dana, Crustacea U. S. Explor. Exped., 1852, 1, p. 527. Type locality: - Fresh-water streams about the Bay of Islands, North Island, New Zealand.

Type locality: - River Thames, North Island, New Zealand. Types, Brit. Mus.

2. Paranephrops zealandicts.

Astaeus zealandieus Thite, Proc. Zoöl. Soe. London, 1S47, part 15, p. 123.

Paranephrops neo-zclanicus C'hilton (in part), Trans. and Proc. New Zealand Inst., 1SSS, 21, p. 249 (nom. emend.).

Type locality: - New Zealand. Types, Brit. Mus.

3. Paranephrops setosus.

Paranephrops setosus Hutton (in part), Ann. Mag. Nat. Hist., Nov. 1873, ser. 4, 12, p. 402 .

Paranephrops horridus "S[cmpcr?] MS.," Miers, Cat. Stalk and Sessileeyed Crust. New Zealand, 1876, p. 73. (nom. nudum). Brit. Mus.

?Astacrïles tridentatus Wood-Mason, Proc. Asiatic Soc. Bengal, 1876, p. 4. Typc locality: - New Zealand.

Type locality: - River Aron, near Christchurch, South Island, New Zealand.

\section{Astaconel'hrops Nobili.}

Astaconephors Nobili, Annali dil Mus. Civ. Storia Nat. Genova, 1899, 40, p. 244.

1. AstaCONEPHROPS ALBERTISII.

Astaconephrops albertisii Nobili, Annali del Mus. Civ. Storia Nat. Genora, 1S99, 40, p. 244.

Type locality: - Katau, southern New Guinea. Type, Genova Mus., 1 \% .

\section{Astacoïnes Guérin.}

Astacol̈bes Guérin, Revue Zoologique, 1839, 2, p. 109.

1. AstacoÏdes Madagascariensis.

Astacus madagascariensis Aud. et M. Edw., Journ. de l'Institut, 1 \$39, p. 152.

Astacoüdes goudotii Guérin, Revue Zoologique, 1839, 2, p. 109. Type locality:- Madagascar. Type, Acad. Nat. Sci. Philad., Guérin Coll., No. 290. 
Astacus ealluclli Bate, Proc. Zoöl. Soc. London, 1865, p. 469. Type locality:- Near Intananarivo, Madagascar.

Type locality: - Madagascar.

\section{Parastacus Huxley. \\ Parastacus Huxley, Proc. Zoöl. Soc. London, 1878, p. 771.}

1. Parastaces pilinanus.

Astacus pilimame Martens, Arch. Naturgesch., 1869, 35, 1, p. 15.

Type locality: - Porto Alegre, Brazil. Types, Berlin MIus., Nos. 3,323, 3,447 .

2. Parastacus brasiliensis.

Astacus brasiliensis Martens, Arch. Naturgeseh., 1869, 35, 1, p. 16.

Type locality: - Porto Alegre, Brazil. Types, Berlin Mus., Nos. 3,322, 3,448 .

3. Parastacus defossus.

Parastacus defossus Faxon, Proe. U. S. Nat. Nus., Feb. 17, 189S, 20, p. 686.

Type locality: - Monterideo, Uruguay. Types, U. S. N. M., No. 19,647; paratype, M. C. Z., No. 4,776.

4. Parastacus Saffordi.

Parastacus saffordi Faxon, Proe. U. S. Nat. Mus., Feb. 17, 1898, 20, p. 683.

Type locality: - Montevideo, Uruguay. Types, U. S. N. M., No. 12,581; paratype, M. C. Z., No. 4,775.

5. Parastacus varicosus.

Parastacus varicosus Faxon, Proe. U. S. Nat. Mus., Feb. 17, 1898, 20, p. 685.

Type locality: - Colima, Mexico (by error?). Type, U. S. N. M., No. 4,133.

6. Parastacus chilensis.

Astacus chilensis M. Edw., Hist. Nat. des Crustacés, 1837, 2, p. 333.

Type loeality: - Coasts of Chile. Type, Mus. Hist. Nat. Paris.

7. Parastacus binaculatus.

Astacus bimaeulatus Philippi, Anales Universidad Chile, 1894, 87, p. 378.

Parastacus agassizii Faxon, Proc. U. S. Nat. Mus., Feb. 17, 1898, 20, 1. 690. Type locality: - Talcahuano, Chile. Typcs, M. C. Z., No. 3,400; paratypes, U. S. N. M., No. 12,045 .

Type loculity: - Chile. 
S. Parastacus spinifrons.

Astacus spinifrons Pliilippi, Inales Universidad Chile, 1882, 61.

Type locality: - Chile.

9. Parastacus nicolett.

Astacus chilcnsis Nicolet (nee M. Edw.), Gay's Hist. Chile, Zool., 1849, 3,

p. 211. Type locality: - Chile.

Astacus nicoleti Philippi, Anales Universidad Chile, 18S2, 61.

Type locality: - Chile.

10. Parastacus 11assleri.

Parastacus hasslcri Faxon, Proc. U. S. Nat. Mlus., Feb. 17, 1898, 20, p. 687.

Type locality: - Talcahuano, Chile. Types, M. C. Z., No. 3,401; paratypes, U. S. N. M., No. 19,689 .

11. Parastacus araucanius.

Parastacus araucanius Faxon, supra, p. 353.

Typc locality: - Corral, Chile. Type, M. C. Z., No. 7,355.

Astacus Fabricius.

Astaces Fabricius, Syst. Entomol., 1775, p. 413.

1. Astaces colchicus.

A stacus colchicus Késsler, Bull. Soc. Imp. Moscou, 1876, 50, p. 2.

Type loculity: - Upper Rion River and tributaries, Transeaueasia.

2. Astacus pachypus.

A stacus pachypus Rathke, Mém. Acad. Imp. St. Pétersbourg, 1S36, 3, p. 365.

A stacus caspius Eichwald, Bull. Soe. Imp. Moscou, 1838, p. 149. Type locality:-Caspian Sea, near Baku.

Typc locality: - Neighborhood of Nikolaiev, Boug River, Russia.

3. Astacus leptodactylus.

Astracus leptodactylus Esehseholtz, Mém. Soe. Imp. Moscou, 1823, 6, p. 109.

A stacus leptodactylus salimes Nordmann, Observations sur la Faune Pontique, in Demidoff's Voyage dans la Russie Méridionale et la Crimée, Atlas, Crustacea, 1842, Tab. 1. Type locality: - Black Sea.

Type locality: - Government of Taurida, Russia. 
3a. Astacus leptodactrlus caspius.

A stacus lcptodactylus, var. caspia Eichwald, Bull. Soc. Imp. Moscou, 1838, p. 148 .

Type locality: - Caspian Sea, near Lenkoran.

3b. Astacus leptodactrlus angUlOsUs.

Astacus angulosus Rathke, Mém. Acad. Imp. Stt. Pétersbourg, 1836, 3, p. 364.

Type locality: - Crimea, Russia.

4. Astacus kesslert.

A stacus kessleri Schinkewitsch, Bull. Soc. Imp. Imis Hist. Nat. Moscou, 18S6, 50 (Proc. Zool. Sect., 1, pt. 1, p. 20).

Type locality: - Near the town of Turkestan, Govermment of Syr-Darya, Asiatic Russia.

5. Astacus astacus.

Cancer astacus Limné, Syst. Nat., Ed. 10, 175S, 1, p. 631.

Astacus fluriatilis Fabr., Syst. Entomol., 1775, p. 413. Type locality: Europe.

Cancer nobilis Schrank, Fauna Boica, 1803, 3, 1 Abth., p. 246. Type locality:-Bavaria.

Aslacus fluviatilis communis Gerstfeldt, Mém. Acad. Inp. St. Pétersbourg, 1859, 9, 1. 554. Type locality: - Europe.

Type locality: - Europe.

6. Astacus pallipes.

Astacus pallipes Lereboullet, Mém. Soc. Sci. Nat. Strasbourg, 1858, 5, 1) 7.

Astacus fontinalis Carbonnier, I’'Ecrerisse, 1S69, p. S. Type Incality:France.

Type locality: - In canals and ditches, Strasbourg, Hsace.

6a. Astacus pallipes fulcisianus.

Astacus pallipes, var. fulcisiana Ninni, Atti Soc. Ital. Ści. Nat. Milano, 1S86, 29, p. 326 .

Type locality: - Province of Belluno, Italy.

6b. Astacus pallipes italicus.

A stacus pallipes italicus Faxon, supra, p. 361. 
Type locality: - River Sarno, Pompeii, Italy. Types, U. S. N. M., No. 28,638; paratypes, M. C. Z., No. 7,409.

7. Astacus torrentium.

Cancer torrentium Sehrank, Fauna Boiea, 1803, 3, 1 Abth., p. 247.

Astacus suxatilis Koch, Deutsehlands Crustaceen, Myriapoden und Araehniden, 1835?, 7, No. 1 (Panzer and Herrieh-Schäffer's Deutschlands Inseeten, 140, No. 1). Type locality: - Bavaria, in mountain brooks of the Oberpfalz and also in the Danube under stones.

Astacus tristis Koch, Deutschlands Crustaceen, Myriapoden und Araeh niclen, 1835?, 7, No. 2 (Panzer and Herrieh-Sehäffer's Deutsehlands Inseeten, 140, No.2). Type Locality: - Bavaria, in a mountain brook at Bodenstein, Regen River system.

A stucus longicormis Lereboullet, Mém. Soc. Sei. Nat. Strasbourg, 1858, 5, p. 2. Type loculity: - Ill and Bruehe Rivers, Alsace.

Typc locality: - Bavaria, in stony streams and also in lakes, e. g. Würm-See.

8. Astacus gambelit.

Cambarus gambelii Girard, Proc. Aead. Nat. Sei. Philad., 1852, 6, p. 90.

Type locality: - "California." Types, Aead. Nat. Sci. Philad.

Sa. Astacus gambeli connectens.

Astacus gambelii connectens Faxon, supra, p. 360.

Type locality: - Snake River, Upper Sahmon Falls, Idaho. Type, U. S. N. M. No. 23,096; paralype, M. C. Z., No. 7,385.

9. Astacus nigrescens.

Astacus nigrescens Stimpson, Proc. Boston Soc. Nat. Hist., Feb., 1857, 6, p. 87.

Type locality: - Neighborhood of San Franeiseo, Cal. Types probably destroyed in the. Chieago fire in 1871.

9a. Astacus nigrescens fortis.

Astacus nigrescens fortis Faxon, supra, p. 360.

Type locality: - Fall River, Fall City Mills, Shasta Co., Cal. Type, U.S. N. M., No. 44,404; paratypes, M. C. Z., No. 7,383.

10. Astacus trewbridgit.

Astacus trowbridgii Stimpson, Proc. Boston Soc. Nat. Hist., Feb., 1857, 6, p. 87 . 
Type locality:-Columbia River above Astoria, Oregon. Cotypes, U. S. N. M., No. 2,080; M. C. Z., No. 3,510; Bost. Soc. Nit. Hist.; Peabody Mus. Yale Univ.

11. Astacus leniusculus.

Astacus leniusculus Dana, Crustacea U. S. Expl. Exped., 1S52, 1, 1. 524.

PAstacus oregamus Randall, Jomrn. Acad. Nat. Sci. Philad., 1S40, 8, p. 138. Type locality: - Columbia River. Type destroyed.

Type locality: - Columbia River and Puget's Sound. Colype, U. S. N. M., No. 2,019, and probably No. 2,161.

12. Astacus KLAMATHENSIS.

Astacus klamathcnsis Stimpson, Proc. Boston Soc. Nat. Hist., Feb., 1S57, 6, p. 87 .

Type locality: - Klamath Lake, Oregon. Type probably destroyed in the Chicago fire in 1871.

\author{
CAMBAROÏDES Faxon. \\ Cambaroödes Faxon, Proc. Amer. Acad., 1884, 20, p. 150.
}

1. Cambaroïdes japonictes.

Astacus japonicus De Haan, Crustacea of Siebold's Fauna Japonica, 1842, p. 164 .

Type locality: - Japan.

2. CambaroÏdes similis.

Astacus (Cambaroüdes) similis Koelbel, Anz. Akad. Wissensch. Wien, math.nat. Classe, 1892, 29, p. 176; Sitzungsber., 1892, 101, pt. 1, p. 650.

Type locality: - Province of Kjöng-Kurur-do, Korea.

3. CambaroÏdes dauuricus.

- Astacus daunricus Pallas, Spicilegia Zoologica, 1772, Fasc. 9, p. 81.

Astacus leptorhinus Fischer, Bull. Soc. Imp. Moseou, 1836, 9, p. 467. Type locality: - Dauria. Types, St. Petersburg Mus. ${ }^{1}$

4. CambaroÏdes schrenckit.

Astucus schrenclii Kiessler, Bull. Soc. Imp. Moseou, 1874, 48, p. 361.

Type locality: - Lower Amur River Basin.

1. $l$., were there when the species was described. 


\section{CAMBARUS Erichson.}

Cambartos Erichson, Arch. Niturgesch., 1846, 12, 1, p. Ss.

\$I. Third segment of the third pair of legs of the male furnished with hooks. First pair of abdominal appendages of the male stout, inner and outer parts closely appressed, laterally compressed, with a holny (in the first form) spine at the tip; anterior margin with a prominent shoulder near the distal end. (Subgemus Procambarus of Ortmamm.)

1. Cambarus diguett.

Cambarus digueti Bouvier, Bull. Mus. Hist. Nat. Paris, 1897, 3, p. 225.

Cambarus carinatus Faxon, Proc. U. S. N. M., Feb. 17, 1898, 20, p. 648. Type locality: - Guadalajara, Mexico." Type, U. S. N. M., No. 17,699, 1 or f. I; paratymes, U. S. N. M., No. 16,085 (Ameca, State of Jalisco, Mex.), 17,707 (Hacienda de Villachuato, State of Michoacan, Mex.); M. C. 7., No. 4,338 (Ameca, Mex.).

Type locality: - Affuents of River Santiago, State of Jalisco, Mexico. Cotypes, Mus. Hist. Nat. Paris; U.S. N. M., No. 30,579; Carnegie Mus. Pittsburgh.

2. Cambarus wilitamsont.

Cambans (Procambarus) williamsoni Ortmamn, Ammals Carnegie Mus., 1905,3, p. 439 .

Type locality: - Los Amates, Province of Izabal, Guatemala. Types, Carnegie Mus. Pittsburgh.

3. Cambarus pilosimanus.

Cambarus (Procambarus) pilosimanus Ortmann, Proc. Washington Acad. Sci., May 3, 1906, 8, p. 6.

Type locality: - Coche, near Coban, Guatemala. Types, Mus. Hist. Nat. Paris; paralypes, Carnegie Mus. Pittsburgh ( 1 or f. I., 1 ㅇ).

4. Cambarus mexicanus.

Astacus (Cambarus) mexicanus Erichson, Arch. Naturgesch., 1846, 12, 1, p. 99.

Cambarus aztecus Saussure, Rev. et Mag. Zool., 1857, ser. 2, 9, p. 503. Type locality: - Tomatlan [State of Tera Cruz?] Mexico. Cotypes, Geneva Mus.; U. S. N. M., No. 20,682 (1 or ex Geneva Mus.).

Cambarus rutheni Pearse, 13th Rept. Mich. Acad. Sci., 1911, p. 110. Type locality: - Cuatotolapam, Canton of Acayucan, State of Vera Cruz, Mexico. Types, Mus. Univ. Michigan, No. 41,704, 41,705, 1 지, 1 우.

Type locality: - Mexico. Type semingly lost from the Berlin Mus. 
5. Canbarus cubensis.

Astacus (Cambams) cubcnsis Erichson, Arch. Naturgesch., 1St6, 12, 1, p. 100 .

Type locality: - Cuba. Typc, Berlin Mus.

5a. Cambarus cubensis consobrinus.

Cambarus lcubensis' consobrinus Saussure, Rev. et. Mag. Zool., 1S57, ser. 2, 9, p. 101 .

Type locality: - Ponds in the central part of Cuba. Cotypes, Genera MIus. $\left(2 \sigma^{7}\right)$; Mus. Hist. Nat. Paris $\left(1 \sigma^{7}\right)$; Berlin Mus. (2 q); U. S. N. M., No. 20,6S4 (1 ơ ex Genera Mus.).

jb. Cambarus cubensis rivalis.

Cambarus cubensis rivalis Faxon, Bull. M. C. Z., October, 1912, 54, p. 459 .

Type locality: - San Diego de los Baños, Province of Pinal del Rio, Cuba. Type, M. C. Z., No. 7,406.

6. Cambarus atkinsont.

Cambarus (Procambarus) atkinsoni Ortmann, Annals Carnegie Mus., May 5, 1913,8, p. 414.

Type locality: - Tributaries of Rio de los Indios, Los Indios, Isle of Pines. Types, Carnegie Mus. Pittsburgh, No. 74,924.

\$I. Third segment of third pair of legs of the male provided with hooks. First pair of abdominal legs of the male truncate, outer part elosely applied to the inner and armed at the tip with from one to three horny, recurved teeth; inner part ending in a sharp spine generally directed ontward. (Subgenus Cambarus of Ortmann, in part.).

7. Cambarus bouvieri.

Cambarus (Cambarus) bouricri Ortmann, Ann. Sci. Nat., 1909, sér. 9, 7, p. 159.

Type locality: - Uruapan, Michoacan, Mexico. Cotypes, Mus. Hist. Nat. Paris (2 of f. I., 1 क ); Carnegie Mus. Pittsburgh ( $1 \sigma^{x}$ f. I.).

S. Cambarus simulans.

Cambarus simulans Faxon, Proc. Amer. Acad., 1SS4, 20, p. 112.

Cambarus gallinus Cockerell and Porter, Proc. Aead. Nat. Sc.i. Philad., 1900, 
p. 434. Type locality: - Gallinas River at Las Vegas, N. Mex. Types, U. S. N. M., No. 23,916; paralypes, M. C. Z., No. 7,342; Acad. Nat. Sci. Philad.

Type locality: - Dallas, Texas. Types, M. C. Z., No. 3,646; paratypes, M. C. Z., No. 3,647; U.S. N. M., No. 4,150; St. Petersburg Mus.

9. Cambarus gracilis.

Cambarus gracilis Bundy, Bull. Illinois State Lab. Nat. Hist., Dec. 1976, 1, p. 5 .

Type locality: - Nommal, McLean Co., Ill., and Racine, Racine Co., Wisconsin. Cotypes, Ill. State Lab. Nat. Hist., Urbana, Ill.; M. C. Z., No. 3,794 (Nomal, Ill.), No. 3,454 (Racine, Wis.).

10. Cambarus hagentanus.

Cambarus hagenianus Faxon, Proc. Amer. Acad., 1884, 20, p. 141.

Type locality: - Charleston, S. C. Type, M. C. Z., No. 232 (1 ơ f. I.).

11. Cambarus adiena.

Cambarus advena LeConte, Proc. Acad. Nat. Sci. Philad., 1855, 7, p. 402.

Type locality: - Lower Georgia. Cotypes, M. C. Z., No. 3,379; Acad. Nat. sici. Pluilad.

\$11. Third segment of third and fourth pairs of legs of the male furnished with a hook. First pair of abdominal appendages of male truncate, outer part closely applied to inner part and armed at the end with from one to three horny recurved teeth; inner part ending in a sharp spine which is often directed outward. (Subgen. Cambarus of Ortmann in part.)

12. Cambarus spiculifer.

Astacus spiculifer Le Conte, Proc. Acad. Nat. Sci. Philad., 1855, 7, p. 401.

Type locality: - Athens, C'larke Co., Georgia. Cotypes, M. C. Z., No. 3,376

(1 ơ f. 1.); Acad. Nat. Sci. Philad. (1 o f. II); paratypes, M. C. Z., No. 172 (11); U.S. N. M., No. 4,962 (1 $\left.\sigma^{7}\right)$; Mus. Hist. Nat. Paris (2).

13. Cambarus versutus.

Cumbarus versutus Hagen, Mem. M. C. Z., 1870, 2, p. 51.

Type locality: - Spring Hill, Mobile Co., Ala. Types, M. C.Z., No. 190; paratypes, U. S. N. M., No. 4,963, $\left(1 \sigma^{7}\right)$; Mus. Hist. Nat. Paris (2); Australian Mus., Sydney.

14. Cambarus pubescens.

Cambarus pubescens Faxon, Proc. Amer. Acad., 1884, 20, p. 109. 
Type locality: - MeBean Creek, Augusta, Georgia. Types, L. .. N. M., No. 3,181 (1 o7. II., 1 क ); paratypes, M. C. Z., No. 3,551 (2 q).

15. Canbarus angustatus.

Cambarus angustatus LeConte, Proe. Acad. Nat. Sci. Philad., 1855, 7, p. 401.

Typc locality: - Lower Georgia, in streams of elear water, between sandhills. Type, Acad. Nat. Sci. Philad. (1 o f. I.).

16. Cambarus lecontei.

Cambarus lecontei Hagen, Mem. M. C. Z., 1870, 2, p. 47.

Type locality: - Mobile, Ala. Types, M. C. Z., No. 217; paratypes, U. S. N. M., No. 4,958; Mus. Hist. Nat. Paris (2); Mus. Würzburg (2); Mus. St. Petersburg (2); Australian Mus., Sydney.

17. Cambarus blandingit.

Astacus blandingii Harlan, Trans. Amer. Philos. Soe., 1830, 3, p. 464.

Type locality: - Marshes and rivulets, Southern United States [Camden, Kershaw Co., S. C.?]. Type, Acad. Nat. Sci. Philad. (I or).

17a. Camibarus blandingit acutus.

Cambarus acutus Girard, Proe. Aead. Nat. Sci. Philad., 1S52, 6, p. 91.

Cambarus acutissimus Girard, Proc. Acad. Nat. Sci. Philad., 1852, 6, p. 91. Type locality: - Affluent of Mobile River, Kemper Co., Miss. Type probably destroyed in the Chieago fire in 1871; paratypes (?), Aead. Nat. Sci. Philad. (2).

Type locality: - Affluent of Mobile River, Kemper Co., Miss. Type probably destroyed in the Chieago fire in 1871 .

18. Cambarus hayt.

Cambarus hayi Faxon, Proc. Amer. Acad., 1S\$1, 20, p. 108.

Type locality: - Maeon, Noxubee Co., Miss. Type, M. C. Z., No. 3,ä33; paratypes, U. S. N. M., No. $19,752,21,850$.

19. Cambarus fallax.

Cambarus fallax Hagen, Mem. M. C. Z., 1S70, 2, p. 45.

Type loculity:-Florida. Cotypes, Boston Soc. Nat. Hist. (1 or f. II.. 1 \&); M. C. Z., No. 3526 (1 or f. I., 1 or f. II.).

90. Cambarus fenerontis.

Cambarus acherontis Lömberg, Bihang K. Svenska Vet.-1kad. Handl., 1894,20 , af. 4, no. 1, p. 6. 
Type locality: - Subterranean rivulet about 42 feet from surface, Lake Brantley, Orange Co., Fla.

21. Cambarus clarkil.

Cambarus clarkii Girard, Proc. Acad. Nat. Sci. Philad., 1S52, 6, p. 91.

Type locality: - Between San Antonio and El Paso del Norte, Texas. Types probably destroyed in the Chicago fire in 1871.

21a. Cambarus clarkit paeninsulanus.

Cambarus clarkii paeninsulanus Faxon, supra, p. 369.

Type locality: - Three miles below Horse Landing, St. John's River, Florida. Type, M. C. Z., No. 3,530 (1 o7, f. II.); paratypes, U. S. N. M., No. 28,557, 25,589; M. C. Z., No. 7,370 (Beecher Point, St. John's Rivel', Fla.).

22. Cambarus troglonytes.

Astacus troglodytes LeConte, Proc. Acad. Nat. Sci. Philad., 1S55, 7, p. 400. Astacus fossarum LeConte, Proc. Acad. Nat. Sci. Philad., 1855, 7, pl. 401. Type locality: - Ditches, Lower Georgia. Cotypes, M. C. Z., No. 3377; Acad. Nat. Sci. Philad.

Type loculity: - Rice-fields, Georgia. Cotypes, M. C. Z., No. 3,375 (هั, f. I.); Acad. Nat. Sci. Phila. (or f. I.).

23. Cambarus evermanni.

Cambarus evermanni Faxon, Proc. U. S. Nat. Mus., May 22, 1890, 12, p. 620 .

Type locality: - Escambia River, at Flomaton, Escambia Co., Ala. Type, M. C. Z., No. 3,834 (1 of f. I.).

24. Cambarus Viaf-Viridis.

Cambarus viae-viridis Faxon, supra, p. 370.

Type locality: - St. Francis River, Greenway, Clay Co., Arkansas. Type, M. C. Z., No. 7,336.

25. Cambarus barbatus.

Astacus penieillotus LeConte (nec Olivier, 1791), Proc. Acad. Nat. Sci. Philad., 1855, 7, p. 401. Type locality: - Lower Georgia.

Cambarus barbatus Faxon, Proc. U. S. Nat. Mus., May 22, 1890, 12, p. 621. Type locality: - Georgia. Type, M. C. Z., No. 279 (1 of f. 1.); paralypes, M. C. Z., No. 3,845, Escambia River, Flomaton, Alabama. 
26. Cambarus mieghann.

Astacus (Cambarus) wicgmanni Erichson, Arehiv Naturgesch., 1846, 12 , 1, p. 99 .

Type locality: - Mexico. Type apparently lost from the Berlin Mus.

27. Cambarus hinei.

Cambarus (Cambarus) hinei Ortmann, Ohio Naturalist, Dec. 1905, 6, p. 401.

Type locality: - Neas Cameron, Cameron Co., La.

28. Cambarus allent.

Cambarus alleni Faxon, Proc. Amer. Aead., 18S4, 20, p. 110.

Type locality: - St. John's River, Hawkinsville, Orange Co., Fla. Type, M. C. Z., No. 3,531 (1 or f. I.).

29. Cambarus pellucidus.

Astacus pellucidus Tellkampf, Areh. Anat. Physiol. wiss. Med., 1844, p. 383.

Orconectes inermis Cope, Amer. Nat., July, 1872, 6, p. 419; 3d and 4th Ann. Rept. Geol. Surv. Indiana, 1S72, p. 173. Type locality: - Wyandotte Cave, Indiana.

Type locality: - Mammoth Cave, Fentucky. Type, Berlin Mus.

29a. Cambarus pellucidus testi.

Cambarus pellucidus, var. testii Hay, Proc. Indiana Acad. Sci., 1891, p. 148; Proe. U. S. Nat. MIus., Sept. 28, 1893, 16, p. 285.

Type locality: - Mayfield's Cave, Momroe Co., Ind. Types, U. S. N. M., No. 17,702 ; paratypes, U. S. N. M., No. $19,765,19,766,22,431$; M. C. Z., No. 7,431 .

\$IV. Third segment of fourth pair of legs of nule booked. Inner and outer parts of the first pair of abdominal appendages of male closely appressed, outer part terminating in a reeurved horny (in form I.) tooth; the inner part giving off a long horny (in form I.) spine at an acute angle with the axis of the limb. (Subgen. Paracambarus of Ortmann.)

30. Cambarus paradoxus.

Cambarus (Paracambarus) paradoxus Ortmann, Proc. Washington Aead. Sei., May 3, 1906, 8, p. 3.

Type locality: - Sierra de Zacapoastla, State of Puebla, Mexico ("ruisseaux torrentueux des montagnes, a le cañada de Tetela de Oeampo"). Types, 
Mus. Hist. Nat. Paris (1 or f. I., 1 or f. II., 1 q); paratypes, Carnegie Mus.

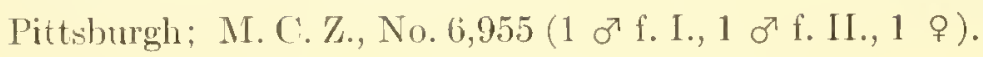

$\$ V$. Third segment of seeond and third pairs of legs of male hooked. First pair of abdominal appendages of male not trumeate, inmer and outer parts separate and divergent for some distanee from the tip; onter branch cleft into two slender tecth at the end; inner branch either acute or spatulate at the tip. (Subg. Cambarellus of Ortmam.)

31. Cambarus shufeldti.

Cambarus shufeldtii Faxon, Proe. Amer. Aead., 1S84, 20, p. 134.

Type locality: - Near New Orleans, La. Cotypes, U.S. N. M., No. 4,860; M. C. Z., No. 3,684.

32. Cambarus montezumae.

Cambarus mantezmmae Saussure, Rev. et Mag. Zool., 1857, sér. 2, 9, p. 102.

Type locality: - Swamps of the Valley of Mexico; specifically, ponds in the park of Chapultepec, Mexico. Cotypes, Geneva Mus.; Berlin Mus.; U.S. N. M., No. 20,683 (ex Geneva Mus.).

32a. Cambarus montezumae dugesit.

Cambarus montezumae dugesii Faxon, Proc. U. S. Nat. Mus., Feb. 17, 189S, 20, p. 660 .

Type locality: - State of Ginanajuato, Mexico. Types, U. S. N. M., No. 16,087; paratypes, M. C. Z., No. 4,339.

32b. Cambarus nontezumae areolatus.

Cambarus montezumae, var. areolata Faxon, Mem. M. C. Z., 18S5, 10, p. 123.

Type locality: - Near Parras, Cohahuila, Mexico. Type, M. C. Z., No. 3,650 .

32e. Cambarus montezunae cilapalanus.

Cambarus chapalanus Faxon, Proc. U. S. Nat. Mus., Feb. 17, 189s, 20, p. 661.

Type locality: - Lake Chapala, State of Jalisco, Mexico. Type, U. S. N. M., No. $17,69 S$ (1 $\left.\sigma^{7}\right)$; paratypes, U. S. N. M., No. 16,294 (2 ơ); M. C. Z., No. $4,777\left(1 \quad \sigma^{7}\right)$.

32d. Cambarus montezumae occidentalis.

Cambarus montezumae necidentulis Faxon, Proc. U. S. N. M., Feb. 17, 189S, 20, p. 661 . 
Type locality: - Mazatlan, State of Cinaloa, Mexico. Types, M. C. \%., No. 3,652 .

\$ V. Third segment of third pair of legs of male hooked. First pair of abdominal appendages of male (usually elongate) split into two rami, straight or somewhat recurved, and acute at the tips. (Sul)g. FAxonius of Ortmann.)

33. Cambarus harrisonit.

Cambarus harrisonii Faxon, Proc. Amer. Acad., 1884, 20, p. 130.

Type locality: - Irondale, Washington Co., Mo. 'Types, MI. C. Z., No. 3,586; paratypes, U.S. N. M., No. $25,826$.

34. Cambarus sloanit.

Cambarus sloanii Bundy, Bull. Illinois State Lab. Nat. Hist., Dec., 1876, 1, p. 24.

Type locality: - New Albany, Floyd Co., Ind. Types, M. C. Z., No. 3,806 (1 ㅇํ f. I., 1 우).

35. Cambarus indianensis.

Cambarus indianensis Hay, 20th Ann. Rept. Depart. Cieol. \& Nat. Resources Indiana, 1896, p. 494.

Type locality: - Patoka River at Patoka, Gibson Co., Ind. Types, U. s. N. M., No. 14,624, 2 o f. I., 2 क ; paratypes, M. C. Z., No. 3,859, 2 or f. I., 2 ㅇ․ 36. Cambarus affinis. 372

?Cambarus limosus Rafinesque, Amer. Monthly Mag. \& Crit. Rev., Nov. 1817, 2, p. 42. Type locality: - In the muddy banks of the Delaware River, near Philadelphia, Pa. (Indeterminable from the description; types not extant.)

Cambarus affinis Say, Journ. Acad. Nat. Sci. Philad., 1S17, 1, p. 168.

Cambarus pealci Girard, Proc. Acad. Nat. Sci. Philad., 1552, 6, p. 87. Type locality: - Potomac River at Washington, D. C. Type, U. S. N. M., No. 2,0S1 (2 $\sigma^{7}, 2$ 우).

Type locality: - Delaware River.

37. Cambarus propinquUs.

372

Cambarus propinques Girard, Proc. Lead. Nat. Fici. Philad., 1852, 6, p. SS.

Type locality: - Garrison Creek, Sacket Harbor, Jefferson Co., N. I., Four-mile Creek, Oswego, Oswego Co., N. I. Types probably destroyed in the Chicago fire in 1871; paratype (?), Acad. Nat. Sei. Philad. (1 $\left.\sigma^{7}\right)$.

37a. Cambarus propineuUs sanborni.

Cambarus sanbornii Faxon, Proc. Imer. Icad., 1884, 20, p. 128. 
Type locality: - Oberlin, Lorain Co., Ohio. Types, M. C. Z., No. 3,692; parutypes, M. C. Z., No. 3,587 (Smoky Creek, Carter Co., Ky.).

38. Cambarus oliscurus.

Cambarus obscurus Hagen, Mem. M. C. Z., 1870, 2, p. 69.

Type locality: - Genesee River, Rochester, Monroe Co., N. Y. Cotypes, M. ('. Z., No. 181, 3,353, 3,354; U. S. N. M., No. 4,971; Mus. Hist. Nat. Paris; Würzburg Mus.; Australian Mus., sydney.

39. Cambaruts erichsonianus.

Cambarus erichsoniamus Faxon, Proc. U. S. Nat. Mus., Feb. 17, 1S98, 20, P. 659 .

Type locality: - Rip Roaring Fork, five miles northwest of Greeneville, Greene Co., Tenn. Cotypes, U.S. N. M., No. 20,787; M. C. Z., No. 4,347.

40. Cambarus rusticts. "3

Cambarus rusticus Girard, Proc. Acad. Nat. Ści. Philad., 1852, 6, p. SS.

Cambarus placidus Hagen, Mem. M. C. Z., 1870, 2, p. 65. Type locality:Lebanon, Wilson Co., Tenm.; Quincy, Adams Co., Ill.; Texas. Cotypes, M. C. Z., No. 289, 296, 170; U. S. N. M., No. 4,966; Mus. Hist. Nat. Paris; IVürzburg Mus.; Australian Mus., Aydney.

Cambanus juvenitis Hagen, Mem. M. C. Z., 1870, 2, p. 66. Type locality: Little Hicknan, Jessanine Co., Ky. Cotypcs, M. C. Z., No. 213, 3,347; U. S. N. M., No. 4,967; Mus. Hist. Nat. Paris; Würzburg Mus.; Australian Mus.

Camburus wisconsinensis Bundy, Bull. Ill. State Lab. Nat. Hist., Dec., 1876, 1, p. 4. Type locality:- Racine, Racine Co., Wisconsin. Type, M. C. Z., No. 3,448 (1 or f. II).

Type locality: - Ohio River, at Cincinnati, Ohio. Types probably destroyed in the Chicago fire in 1871; paratype (?), Acad. Nat. Sei. Philad.

41. Cambarus Forceps.

Cambarus forceps Faxon, Proc. Amer. Acad., 1884, 20, p. 133.

Type locality: - Cypress Creek, Lauderdale Co., Ala. Cotypes, U. S. N. M., No. 4,8s0; M. C. Z., No. 3,582 .

42. Cambarus neglectus.

Cambarus neglectus Faxon, Bull. Washburn College Lab. Nat. Hist., Oct. 31, $18 S 5,1$, p. 142.

Type locality: - Mill Creek. Wabaunsee Co., Kansas. Cotypes, M. C. Z., No. 3,757; Mus. Washbunn College, Topeka, Kans. 
43. Cambarus spinosus.

Cambarus spinosus Bundy, Proc. Acad. Nat. Sci. Philad., 1877, p. 173.

Type locality: - Etowah, Oostanaula, and Coosa Rivers, near Rome, Floyd Co., Georgia. Colypes, M. C. Z., No. 3,540, 3,541 ( o f. II., 3 q); U.S. N. MI., No. 19,779 (3 or f. II., 2 \&).

43a. Cambarus spinosus gulielia.

Cambarus spinosus gulielmi Faxon, supra 1). 375.

Type locality: - Near Rossville, Walker Co., Cieorgia. Types, U.S. N. MI., No. 26,379; paratypes, M. C. Z., No. 7,448 (1 or f. II., 1 ㅇ).

\section{Cambarus putnami.}

Cambárus putnami Faxon, Proc. Amer. Acad., 1S54, 20, p. 131.

Type locality: - Bear Creek, a tributary of Green River, Grayson Springs, Grayson Co., Ky. Types, M. C. Z., No. 3,568; paralypes, M. C. Z., No. 3,569 (Green River, near Mammoth Cave, Ky.), No. 3,570 (Rocky Creek, near Grayson Springs, Ky., 1 ₹) ; U. S. N. M., No. 10,130 (Grayson Springs, Ky.); St. Petersburg Mus. (Green River, Ǩy., 1 ơ , 2 우).

45. Cambarus hylas.

Cambarus hylas Faxon, Proc. U. S. Nat. Miss., May 22, 1890, 12, p. 632.

Type locality: - West Fork of Black River, Reynolds Co., Mo. Types, M. C. Z., No. 3,85S; paratypes, U. S. N. M., No. 25,827 (1 o7, 1 ㅇ).

46. Cambarus medius.

Cambarus medius Faxon, Proe. Amer. Acad., 1S\$4, 20, p. 121.

Type locality: - Irondale, Washington Co., Mo. Types, M. C. Z., No. 3,585 ( 1 or f. I., 1 ㅇ).

47. Cambarus compressus.

Cambarus compressus Faxon, Proc. Amer. Acad., 18S4, 20, p. 127.

Type locality: - Second Creek, Waterloo, Lauderdale Co., Ala. Cotypes, U. S. N. M., No.4,87S; M. C. Z., No. 3,583.

48. Cambarus meeti.

Cambarus meeli Faxon, Proc. U. S. Nat. Mus., Feb. 17, 1898, 20, p. 657.

Type locality: - Walnut Fork of Big Piney Creek, Swain, Newton Co., Ark. Types, M. C. Z., No. 4,303; paratypes, U. S. N. II., No. 19,680; Mus. Zool. Torino. 
49. Cambarus longidigitus.

Cambarus longidigitus Faxon, Proc. U. S. Nat. Mus., Feb. 17, 1898, 20, p. 653.

Cambarus whitmani Stecle, Univ. Cineinnati Bull., 1902, no. 10, p. 24. Type locality: - James River, Mo.

Type locality: - Oxford Bend, White River, [Izard Co.?], Ark. Types, M. C. Z., No. 4,364; paratypes, U. S. N. MI., No. 19,683.

50. Cambarus virilis.

Cambarus viritis Hagen, Mem. M. C. Z., 1870, 2, p. 63.

Cambarus debilis Bundy, Bull. Illinois State Lab. Nat. Hist., Dec., 1876, 1, p. 24. Type locality: - Baraboo River, Ironton, Sauk Co., Wis. Cotype, M. C. Z., No. 3,449 (1 ơ f. II.).

Cambarus concsi Streets, Bull. U. S. Geol. Surv. Terr., 1877, 3, p. 803. Typc locality: - Red River of the North, near Pembina, Pembina Co., N. Dakota. Cotypes, U. S. N. MI., No. 3,154 ; M. C. Z., No. 3,545.

Cambarus viridis Moenkhaus, Proc. Indiana Acad. Sei. for 1902, 1903, p. 111 (per errorem vice "viritis").

Type locality:-Lake Superior. 'Types, M. C. Z., No. 1,151; paratypes, M. C. Z., No. 194, 203 (Lake Superior), No. 196 (Quincy, Ill.), No. 3,342 (Lake Wimnipeg), No. 3,343 (Red River of the North), No. 3,344 (Saskatchewan River); Mus. Hist. Nat. Paris (Lake Superior); Würzburg Mus. (Lake Superior); Australian Mus., Sydney.

51. Cambarus pilosus.

Cambarus pilosus Hay, Proc. U. S. Nat. Mus., Oct. 11, 1S99, 22, p. 121.

Type locality: - Beloit, Mitehell Co., Kansas. Cotypes, U. S. N. M., No. 19,761 (6 요. II.); M. C. Z., No. 7,389 (1 ठ f. II.).

52. Cambarus alabamensis.

Cambarus alabamensis Faxon, Proc. Amer. Acad., 1884, 20, p. 125.

Type locality: - Second Creek, Waterloo, Lauderdale Co., Ala. Cotypes, U.S. N. M., No. 4,876; M. C. Z., No. 3,565.

53. Cambarus nais.

Cambarus nais Faxon, Bull. Washburn College Lab. Nat. Hist., 1885, 1, p. 140 .

Type locality: - Labette Co., Kansas. Cotypes, Mus. Washburn College, Topeka, Kan.; M. C. Z., No. 3,755. 
54. Cambarus muUnis. $p 370$

Cambarus immunis Hagen, Mem. M. C. Z., 1870, 2, p. 71.

Cambarus signifer Herrick, 10th Inn. Rept. Cicol. Surv. Minn., 1882, p. 253. Type locality: - Grass Lake, Richfield, Hennepin Co., Minn. Cotype, M. C. Z., No. 3,515, (2 o f. I., 1 우).

Type locality: - Lawn Ridge, III. Types, M. C. Z., No. 1SS; paratypes, M. C. Z., No. 3,355 Belleville, Saint Clair Co., Ill.); MIus. Hist. Nat. Paris (Lawn Ridge, Ill., 1 o').

54a. Cambarus imuunis spinirostris.

Cambarus immumis spinirostris Faxon, Proe. Amer. Aead., 1SS4, 20, p. 146.

Type locality: - Creek running into the east side of Redfoot Lake, near Idlewild Hotel, Obion Co., Teunessee. Cotypes, U. S. N. M., No. 4,655; M. C. Z., No. 3,562 .

55. Cambarus validus.

Cambarus validus Faxon, supra, p. 382.

Type locality: - Huntsville, Madison Co., Ala. Type, M. C. Z., No. 301 (1 ơ f. I.).

56. Cambarts PALMeri.

Cambarus palmeri Faxon, Proc. Acad., 18S4, 20, p. 124.

Type locality: - Creck ruming into the east side of Redfoot Lake, near Idlewild Hotel, Obion Co., Tenn. Cotypes, U. S. N. M., No. 4,872; M. C. Z., No. 3,564 .

56a. Cambarus palmeri longimanus.

Cambarus palmeri longimanus Faxon, Proc. U. S. Nat. Mus., Feb. 17, 1S9S, 20, p. 655 .

Type locality: - Red River, Arthur City, Lamar Co., Texas. Types, M. C. Z., No. 7,390; paratypes, M. C. Z., No. 4,361, 4,362, (Cioorlland, and Kiamichi, Indian Terr. [now Oklahoma]); U. S. N. M., No. 19,684 (Arthur, Tex., Indian Terr.); Mus. Zool. Torino.

57. Cambarus difficilis.

Cambarus difficilis Faxon, Proc. U. S. Nat. Mus., Feb. 17, 1898, 20, p. 656.

Type locality: - Creek tributary to a southern branch of the Canadian River, Medlester, Pittslourg Co., Oklahoma. Types, M. C. Z., No. 4,359; paratypes, U. S. N. M., No. 19,687; Mus. Zool. Torino. 
58. Cambarts mississippiensis.

Cambarus mississimpiensis Faxon, Proc. Imer. Acad., 1854, 20, p. 123.

Type locality: - Macon, Noxubee Co., Miss. Types, Coll. O. P. Hay; paratype, M. C. Z., No. 3,563 (1 ㅇ) .

59. Cambarus lancifer.

Cambarus laneifer Hagen, Men. M. C. Z., 1870, 2, p. 59.

Cambarus faronii Neek, Iner. Nat., Dec. 1894, 28, p. 1042. Type locality: St. Francis River at Greenway and Big Bay, Lrkansas. Cotypes, U. S. N. M., No. 19,331; M. C. Z., No. 4,220; Mus. Zool. Torino.

Type locality: - Root Pond, Miss. Type, M. C. Z., No. 306 (1 万 f. I.).

\$VII. Third segment of third pair of legs of male hooked. First pair of abdominal appendages of male short and thick, terminating in two large reeurved tooth-like processes, the larger formed by the outer part of the appendage, the smaller by the imner. (Subgen. BarTonius of Ortmamn.)

60. Cambarus hamulatus.

Orconectes hamulatus Cope and Packard, Amer. Nat., Nov. 1881, 15, p. 881.

Type locality: - Nickajack Cave, Tennessee. Cotypes, M. C. Z., No. 3,678 (1 o' f. II., 1 ㅇ ).

61. Cambarus setosus.

Cambarus setosus Faxon, Bull. M. C. Z., Dec. 1889, 17, p. 237.

Type locality: - Wilson's Cave, Jasper Co., Missouri. Types, M. C. Z., No. 4,200; paratypes, M. C. Z., No. 4,201, 4,202; U. S. N. M., No. 25,82S.

62. Cambarus ayersil.

Cambarus ayersii Steele, Univ. Cincinnati Bull., 1902, No. 10, p. 18.

Type locality: - Fisher's Cave, near Springfield, Greene Co., Missouri.

63. Cambarus extraneus.

Cambarus extraneus Hagen, Mem. M. C. Z., 1870, 2, p. 73.

Type locality: - Tennessee River, Temm., near the boundary of Georgia. Types, M. C. Z., No. 175; paralype, U. S. N. M., No. 4,957.

63a. Cambarus extraneus girardianus.

Cambarus givardianus Faxon, Proe. Amer. Acad., 1S\$4, 20, p. 117.

Type locality:-Cypress Creek, Lauderdale Co., Ala. Colypes, U. S. N. M., No. 4,882; M. C. Z., No. 3,560 . 
64. Cambarus jordani.

Cambarus jordani Faxon, Proe. Amer. Acad., 18\$4, 20, p’. 119.

Type locality: - Etowah River, near Rome, Floyd Co., Georgia. Type, M. C. Z., No. 3,561 (1 ơ f. II.).

65. Cambarus connutus.

Cambarus cornutuis Faxon, Proe. Inıer. Aead., 1SS4, 20, p. 120.

Type locality: - Green River near Mammoth Cave, Kentucky. Type, M. C. Z., No. 3,566 (1 శ7 f. I.).

66. Cambarus bartonit.

Astacus bartonii Fabricius, Suppl. Entomol. Syst., 1798, p. 407.

A stacus ciliaris Rafinesque, Imer. Monthly Mag. and Crit. Rev., Nov. 1817,

2, p. 42. Type locality:-Brooks near Fishkill, Dutchess Co., and Newburgh, Orange Co., New Tork.

Astacus pusillus Rafinesque, Amer. Monthly Mag. and Crit. Rer., Nor. 1S17, 2, p. 42. Type locality: - Brooks near Saratoga Springs, Saratoga Co., N. I.; Lake George, N. Y.; Lake Champlain; Utica, Oneida Co., N. Y.; Oswego, Oswego Co., N. Y.

Type locality:- North America [probably neighborhood of Philadelphia, Pa.]. Type (fragment only), Kiel Nusemm.

66a. Cambarus bartonil carinimostris.

Cambarus bartonii carinirostris Hay, supra, p. 384.

Type locality: - Gandy Creek, Osceola, Randolph Co., West Virginia. Type, U. S. N. M., No. 23,962; paratypes, M. C. Z., No. $7,399$.

66b. Cambarus bartonil montanus.

Cambarus montames Girard, Proc. Acad. Nat. Sei. Philad., 1S52, 6, p. S8.

Type locality: - Within the Alleghany ranges in Virginia, West Virginia, and Maryland; tributaries of James River, Rockbridge Co., Va.; Shenandouh River, Clarke Co., Va.; Cumberland, Allegany Co., Md.; Silphur Spring, Greenbrier River, II. Va. Types probably destroyed in the Chieago fire in 1S71; paratype (?), Acad. Nat. Sci. Philad. (1 ơ jur., James River, Va.).

66e. Cambarus bartonit robustus.

Cambarus robustus Girard, Proc. Aead. Nat. Sci. Philad., 1S52, 6, p. 90.

Type locality:-Humber River, near Toronto, Canada. Type probably destroyed in the Chicago fire in 1S71; paratype (?), Acad. Nat. Sci. Philad. $\left(1 \sigma^{7}\right)$. 
66d. Cambarus bartonit longirostris.

Cambarus bartonii, var. longirostris Faxon, Mem. M. C. Z., Oct. IS85, 10, p. 64 .

Cambarus bartonii spinirostris Faxon, Proe. U. S. Nat. Mus., May 22, 1890, 12, p. 623 (lapsu calami pro "longirostris").

Type locality: - Near the boundary between western North Carolina and eastern Tennessee. Type, M. C. Z., No. 3,629 (1 ơ f. II.).

66e. Canbarus bartoni longulus.

Cambarus longulus Girard, Proe. Acad. Nat. Sci., Philad., I852, 6, 1* 90.

Type locality: - Unknown; "its range however, is within the Middle States of the Union." Type probably destroyed in the C'licago fire in 1871.

66f. Cambarus bartoni veteranus.

Cambarus bartonii veteranus Faxon, supra, p. 389.

Type locality: - Indian Creck, Baileysville, Wyoming Co., West Virginia. Type, U.S. N. M., No. 44,712; paratypes, U.S. N. M., No. 25,020; M. C. Z., No. 7,402 .

66g. Cambarus bartonit asperimanus.

Cambarus bartonii asperimanus Faxon, supra, p. 391.

Type loeality: - Flat Creek, near Montreat, Buncombe Co., N. C. Types, U. S. N. M., No. 47,375 (2 ठ f. I.). $3=4$

66h. Cambarus bartonil acuminatus.

Cambarus acuminatus Faxon, Proc. Amer. Acad., 1S\$4, 20, p. 113.

Type locality: - Saluda River at Farr's Mills, west of Greenville, Greenville Co., Sonth Carolina. Cotypes, Butler Univ., Irvington, Ind. (1 or f. II., 1 ㅇ); M. C. Z., No. 3,624 (I ㅇ).

66i. Cambarus bartonil laevis.

Cambarus bartonii laevis Faxon, supra, p. 391.

Type locality: - Bloomington, Monroe Co., Indiana. Types, M. C. Z., No. 3,812 .

66j. Cambarus bartonit tenebrosus.

Cambarus bartonii tenebrosus Hay, Proc. U. S. Nat. Mus., Sept. 12, 1902, 25, p. 232 .

Type locality: - Mammoth Cave, Kentucky. Types, U. S. N. M., No. 22,346 . 
66k. Cambarus bartonil cavatus.

Cambarus bartonii cavatus Hay, Proc. U. S. Nat. Mus., Sept. 23, 1902, 25, p. 435 .

Type locality: - Powell River at Tazewell, Claiborne Co., Tennessee. Types, U. S. N. M., No. $25,017$.

67. Cambarus latimanus.

Astacus latimanus LeConte, Proc. Acad. Nat. Sci. Philad., 185.5, 7, p. 402.

Type locality: - Athens, Clarke Co., Georgia. Cotypes, M. C. Z., No. 3,37S (1 or f. I); Acad. Nat. Sci. Philad. (1 q); paratypes, M. C. Z., No. 236.

67a. Cambarus latimanus striatus.

Cambarus latimanus striatus Hay, Proc. U. S. Nat. Mus., Sept. 23, 1902, 25, p. 437.

Type locality: - Nashville, Teun. Type, U.S. N. M., No. 25,019; paratype, M. C. Z., No. 7,348.

6S. Cambarus graysoni.

Cambarus graysoni Faxon, supra, p. 393.

Type locality: - Bear Creek, Grayson Springs, Grayson Co., Kentucky. Types, M. C. Z., No. 3,593.

69. Cambarus ortmanni.

Cambarus ortmanni Williamson, 31st Ann. Rept. Dept. Geol. Indiana, 1907, p. 754 .

Type locality: - Six-Mile Creek and Craven Ditch, tributary to Wabash River, above Bluffton, Wells Co., Indiana. Typcs, Carnegie Mus., Pittsburgh: paratypes, Coll. W. P. Hay; M. C. Z., No. 7,5S7 (1 q).

70. Cambarus carolinus.

Astacus (Cambarus) carolinus Erichson, Arch. Naturgesch., 1846, 12, p. 96. Type locality: - Farm called "Tiger Hall," near Greenville, Greenville Co., S. C. Type, Berlin Mus. (1 ơ).

70a. Cambarus carolinus dubius.

Cambarus dubius Faxon, Proc. Amer. Acad., 18St, 20, p. 114.

Type locality: - Crambery Summit [now Terra Alta], Preston Co., West Virginia. Type, M. C. Z., No. 3,631.

70b. Cambarus carolinus monongalensis.

Cambarus mọnongalcnsis Ortmann, Annals Carnegie Mus., 1905, 3, p. 395. 
Type locality: - Head of Gordon's Valley, Edgewood Park, Allegheny Co., Pa. Types, Carnegie Mus.; paratypes, M. C.Z., No. 6,953; U. S. N. M., No. 30,613 .

71. Cambarus diogenes.

Cambarus diogenes Girard, Proc. Acad. Nat. Sci. Philad., 1852, 6, p. 88.

?Cambarus nebraseensis Girard, Proc. Acad. Nat. Sci. Philad., 1S52, 6, p. 91. Type locality: - Fort Pierre, Nebraska [now in Stanley Co., South Dakota].

Cambarus obesus Hagen, Mem. M. C. Z., 1870, 2, p. 81. Type locality: Lawn Ridge, Illinois. Types, M. C.Z., No. 195; paratypes, M. C. Z., No. 165 (Belleville, Saint Clair Co., Ill.), No. 336 (Evanston, Cook Co., Ill.), No. 229 (Arkansas), No. 3,363 (Petersburg, Dinwiddie Co., Va.); Mus. Hist. Nat. Paris (Lawn Ridge, Ill., Belleville, Ill.); St. Petersburg Mus. (Belleville, Ill.).

Type locality: - Near Washington, D. C. Paratype (?), Acad. Nat. Sci. Philad.

71a. Cambarus diogenes ludovicianus.

Cambarus diogenes, var. ludoviciana Faxon, Proc. Amer. Acad., 1884, 20, p. 144 .

Type locality: - New Orleans, La. Cotypes, U. S. N. M., No. 5,625; M. C. Z., No. 3,617.

72. Cambarus argillicola.

Cambarus argillicola Faxon, Proc. Amer. Acad., 1S84, 20, p. 115.

Type locality: - Detroit, Mich. Types, M. C. Z., No. 3,459.

73. Cambarus uhleri.

Cambarus uhleri Faxon, Proc. Amer. Acad., 1SS4, 20, p. 116.

Type loeality: - Swamp on Eastern Road near Felsburg, Somerset Co., Maryland. Type M. C. Z., No. 3,634 (1 o f. I.); paratypes, M. C. Z., No. 3,633, 3,635, 3,636 (Dorchester, Somerset, and Worcester Cos., Md.).

74. Cambarus clypeatus. ${ }^{1}$

Cambarus clypeatus Hay, Proc. U. S. Nat. MIus., Oct. 11, 1S99, 22, p. 122.

Type locality: - Bay saint Louis, Hancock Co., Miss. (found in a skiff). Type, U. S. N. M., No. 22,778 ( 
DOUBTFUL SPECIES, NOT INCLUDED IN THE PRECEDING LIST.

1. Cambarus maniculatus.

Astacus maniculatus LeConte, Proc. Icad. Nat. Sci. Philad., 1855, 7, p. 401. Typc locality: - In ditches, Lower Georgia.

2. Cambarus stygius.

Cambarus stygius Bundy, Bull. Illinois State Lab. Nat. Hist., 1S76, 1, p. 3.

Type locality: - Lake Michigan at Racine, Racine Co., Wisconsin (washed up during a violent storm).

3. Cambarus typhlobius.

Cambarus typhlobius Joseph, 57th Jahresber. Schlesischen Gesellsch. vaterl. Cult., 1879, 1880, p. 202.

Cambarus coecus Joseph, Berl. Entomol. Zeitsclır., Dee. 1851, 25, p. 237.

Cambarus stygius Joseph, Berl. Entomol. Zeitschr., April, 1Ss2, 26, p. 12 (nee Bundy, 1876).

Type locality: - Recea River, Grotto of St. Kanzian at Metaùn, near Divazza, Carniola (doubtless an error). 

EXPLANATION OF PLATES.

Note.- Plates 1-3 are after colour-drawings of living specimens, by E. N. Fischer. Plates 4- 8 are from India-ink drawings by E. N. Fischer. Plates $9-13$ are from photographs by George Nelson. 

PLATE 1. 
PLATE 1.

Fig. 1.-Camburus hugrnianus Faxon. क. Muldon, Miss. M. C. Z., No. 7,425. $\quad \times 1$. Fig. 2.-Camburne hagenianus Faxon. OP. Muldon, Miss. M. C. Z., No.7,425. $\times 1$. 


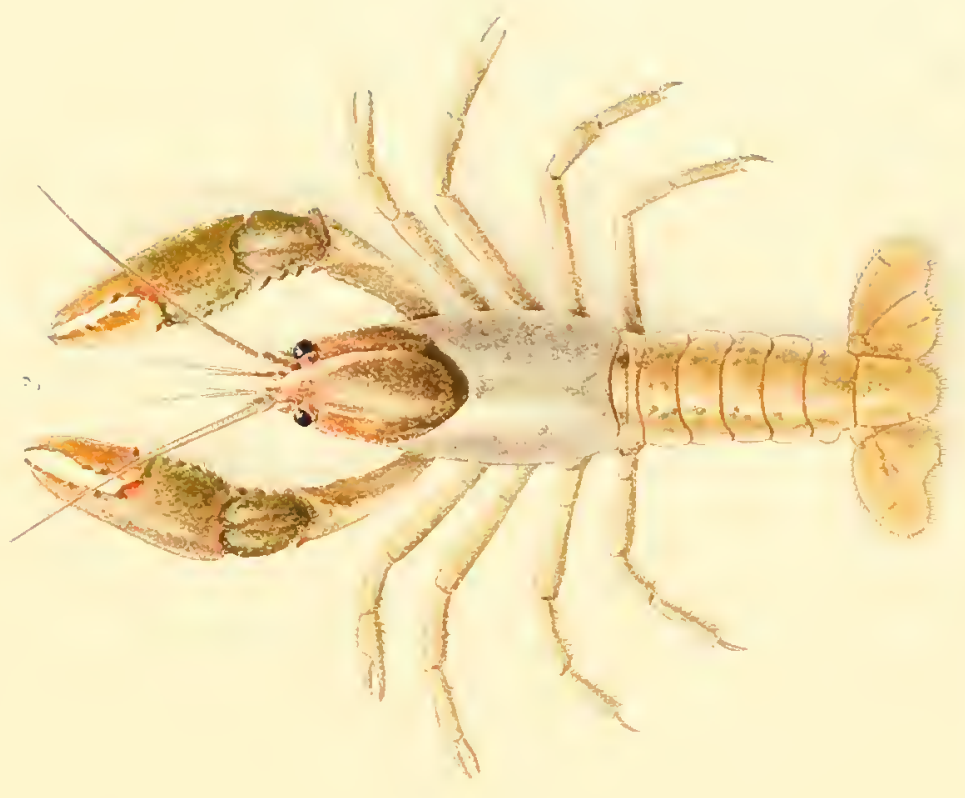

$\overrightarrow{0}$
0
0
0
$\sum$
0
0
$\sum$
$\sum$
$\Sigma$
$\Sigma$
$\Sigma$
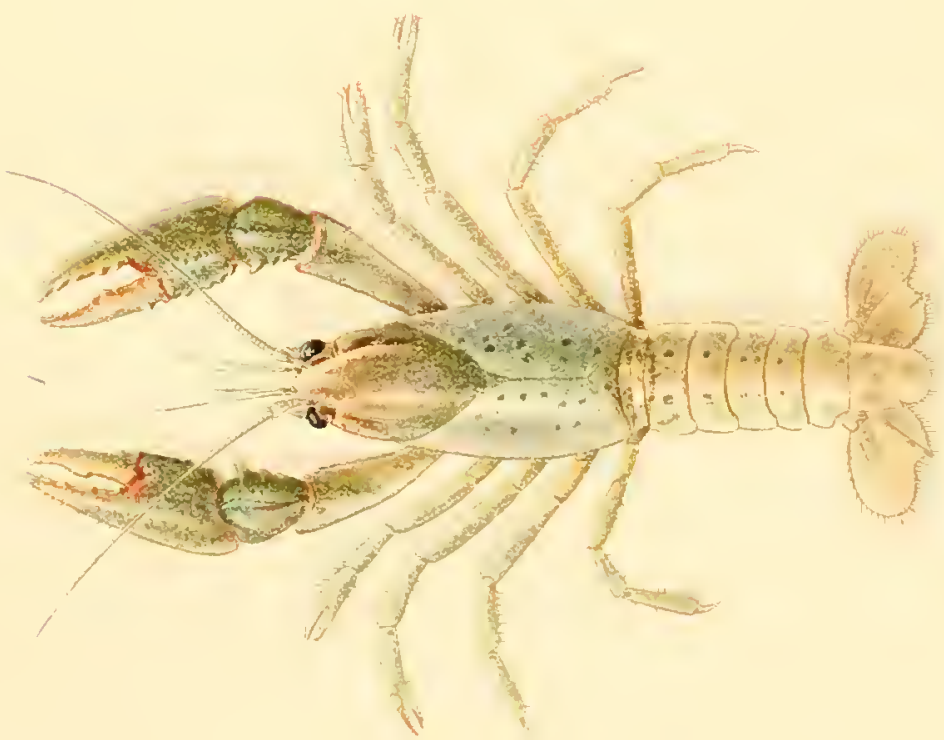
. 
PLATE 2. 


\section{PLATE 2.}

Fig. 1.- Cambarus immunis spimiostris Faxon. Young o. Pontoosuc Lake, Lanesboro, Mass, Aug. 12, 1911. M. C. Z., NTn. 7,364. ×3.

Fig. 2.-Camburus immunis spinirostris Faxon. of, form I. Pontoosuc Lake, Lanesboro, Mass., Aug. 12, 1911. M. C. Z., No. $7,363 . \times 1$. 


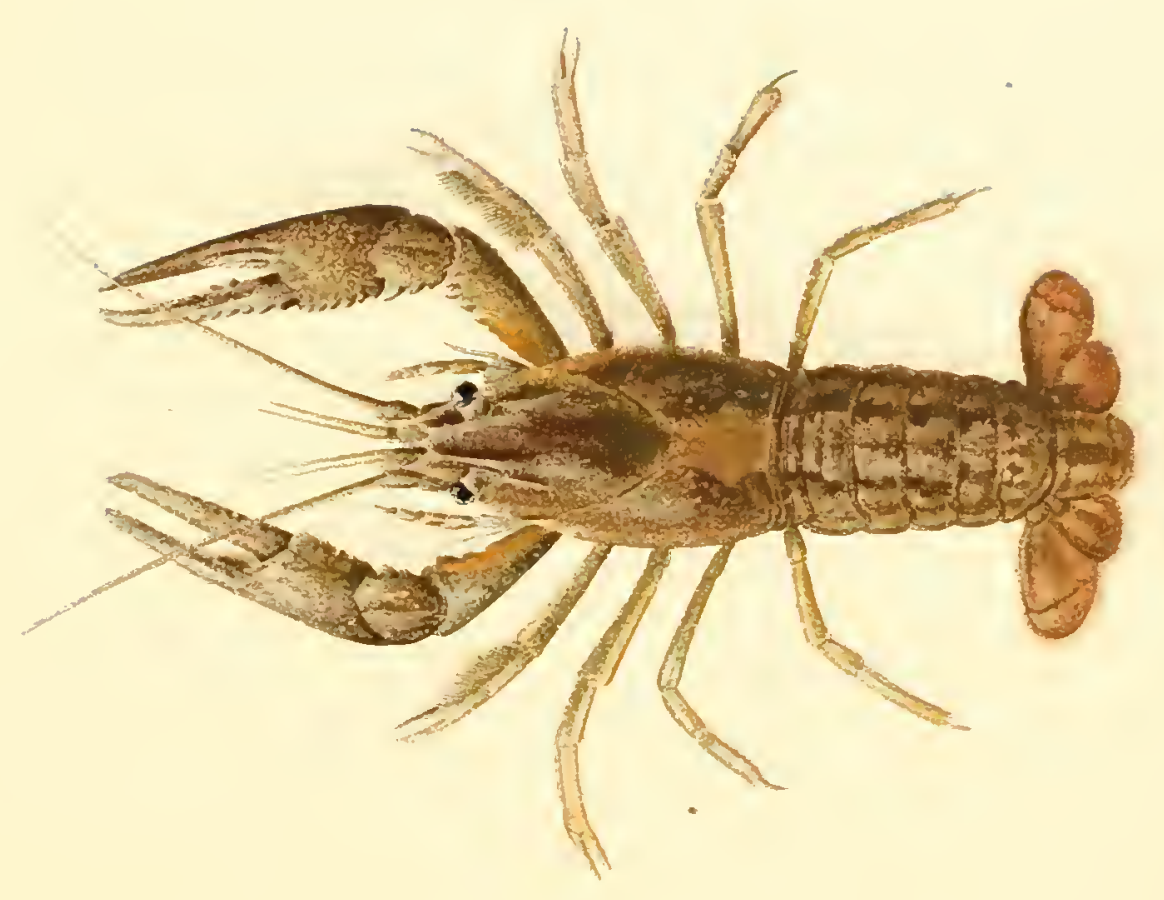


PLATE 3. 
PLATE 3.

Cambarus bartonii robustus (Girard). Bog River, St. Lawrence Co., N. Y., July, 1912. M. C. Z.. No. $7,440 . \times 1 \frac{1}{2}$. 


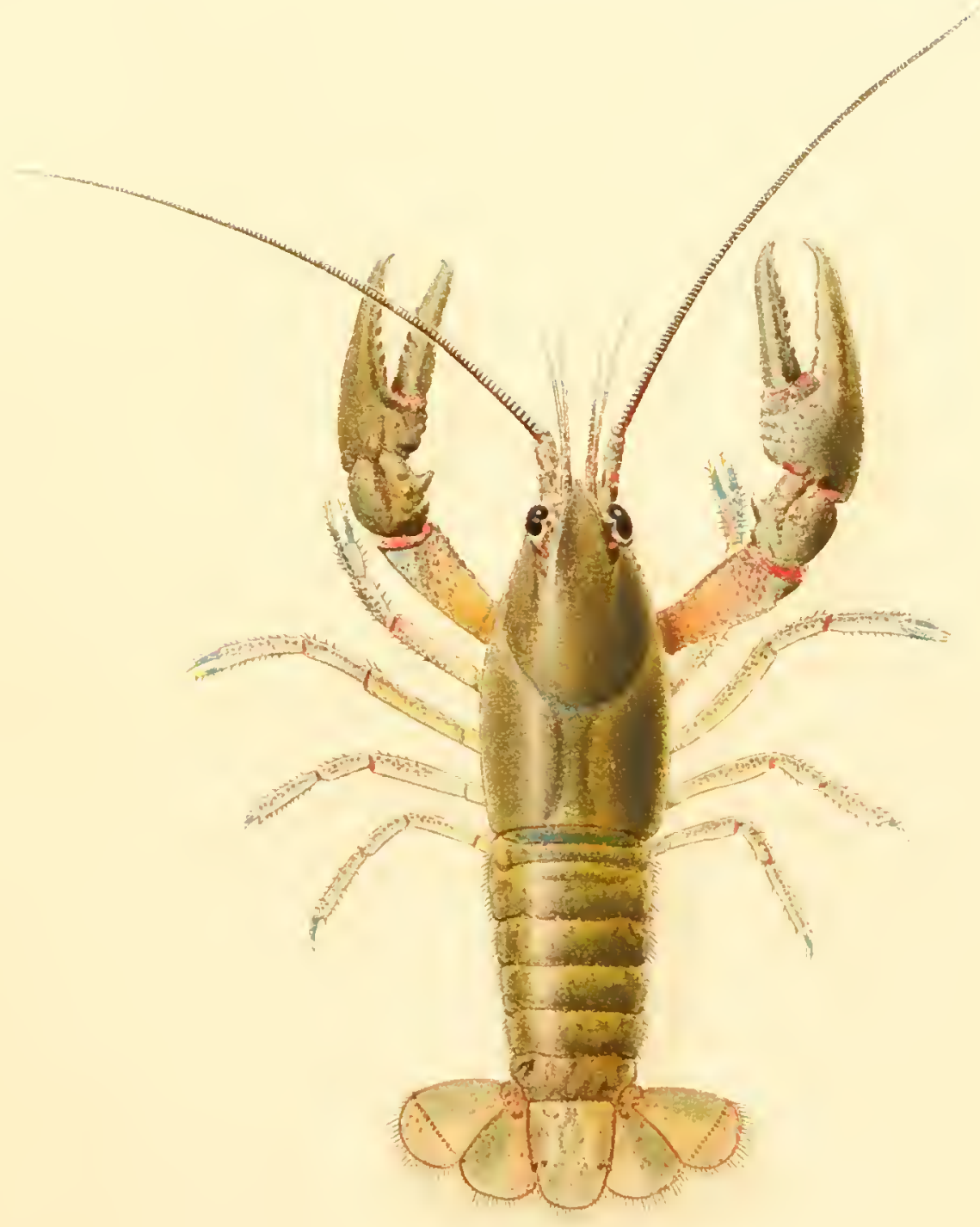



PLATE 4. 


\section{PLATE 4}

Fig. 1.- Parastacus araucunius Faxon. -7. Corral, Chile, Dee. 15, 1905. Trpe. M. C. Z., Jo. 7,355 .

Fig. 2.- Epistoma of the sine.

Fig. 3.- Antennal seale from the right antenaa, upper face. 


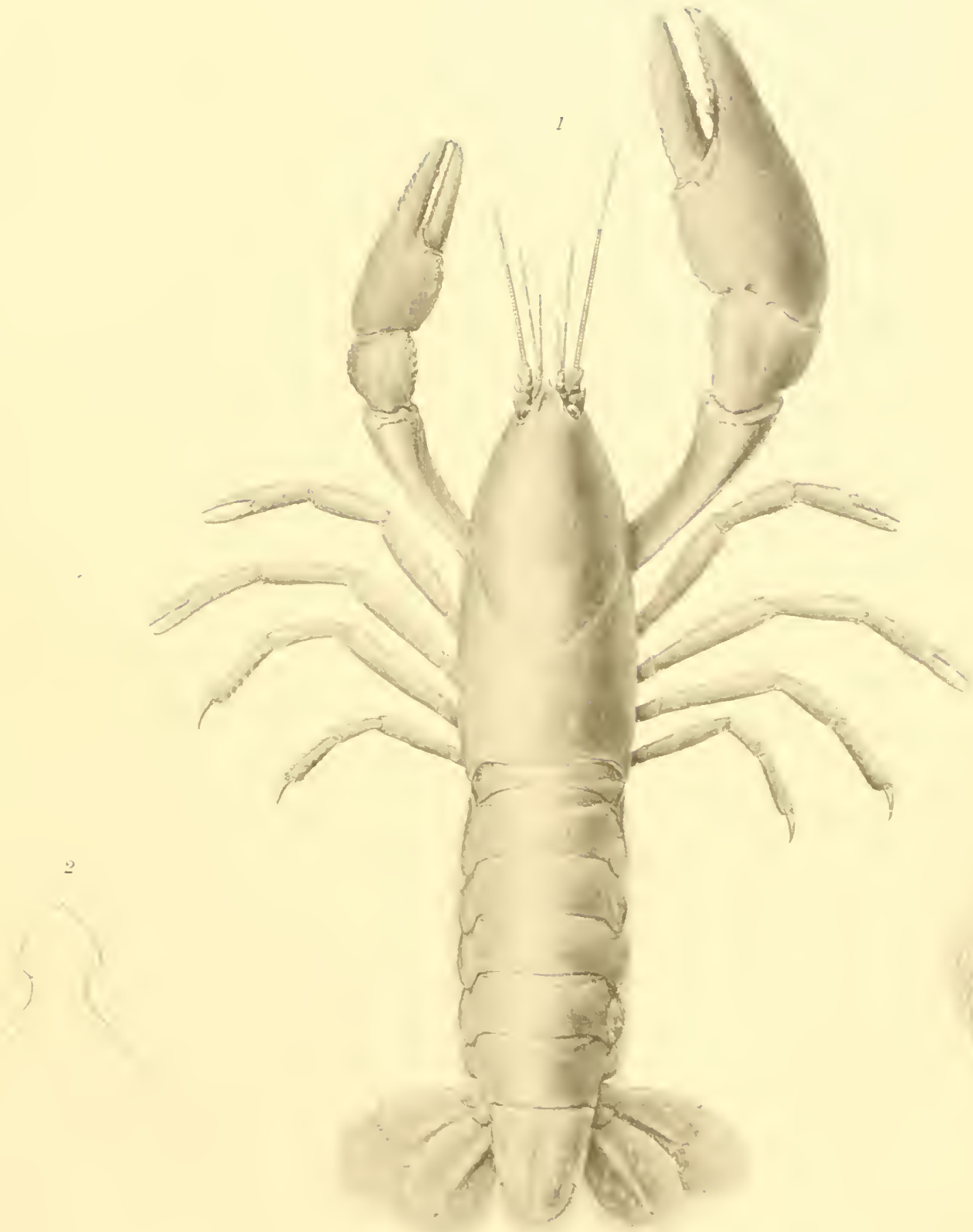



PL.ITE 5.

1 
PLATE 5.

Fig. 1.-Cambarus vinc-mindis Faxon. ơ, form I. St. Francis R., Greenway, Ark., Aug., 1894. Type. M. C. Z., No. 7,336.

Fig. 2.- Epistoma of tlie same.

Fig. 3.- Antronnal scale of the same.

Fig. 4- Gonopod of the same, inner side.

Fig. 4a.- Gonopod of the same, onter side.

Fig. 5.- Right eheliped of the same.

Fig. 6.- Annulus ventralis of the female Cambarus viac-viridis. 


$$
\frac{1}{1}
$$



PLATE 6. 
PLATE 6.

Fig. 1.-Cambanus immunus spinirostris Faxon. Pontoosue Lake, Lanesboro, Mass., Aug. 12, 1911. M. C. Z., No.7,363. Gronopod of the $\sigma^{7}$, form I. I $a$, outsicle, $1 b$, front, $1 c$, inside.

Fig. 2.- Gonoporl of the $\sigma^{7}$, form II of the same, $2 a$, ontside, $2 b$, front, $2 c$, inside.

Fig. 3.- Epistonia of the same.

Fig. 4.- Antennal scale of the same.

Fig. 5.- Annulus ventralis of the of of the same.

Fig. 6.- Chela of the of, form I. of the same. 

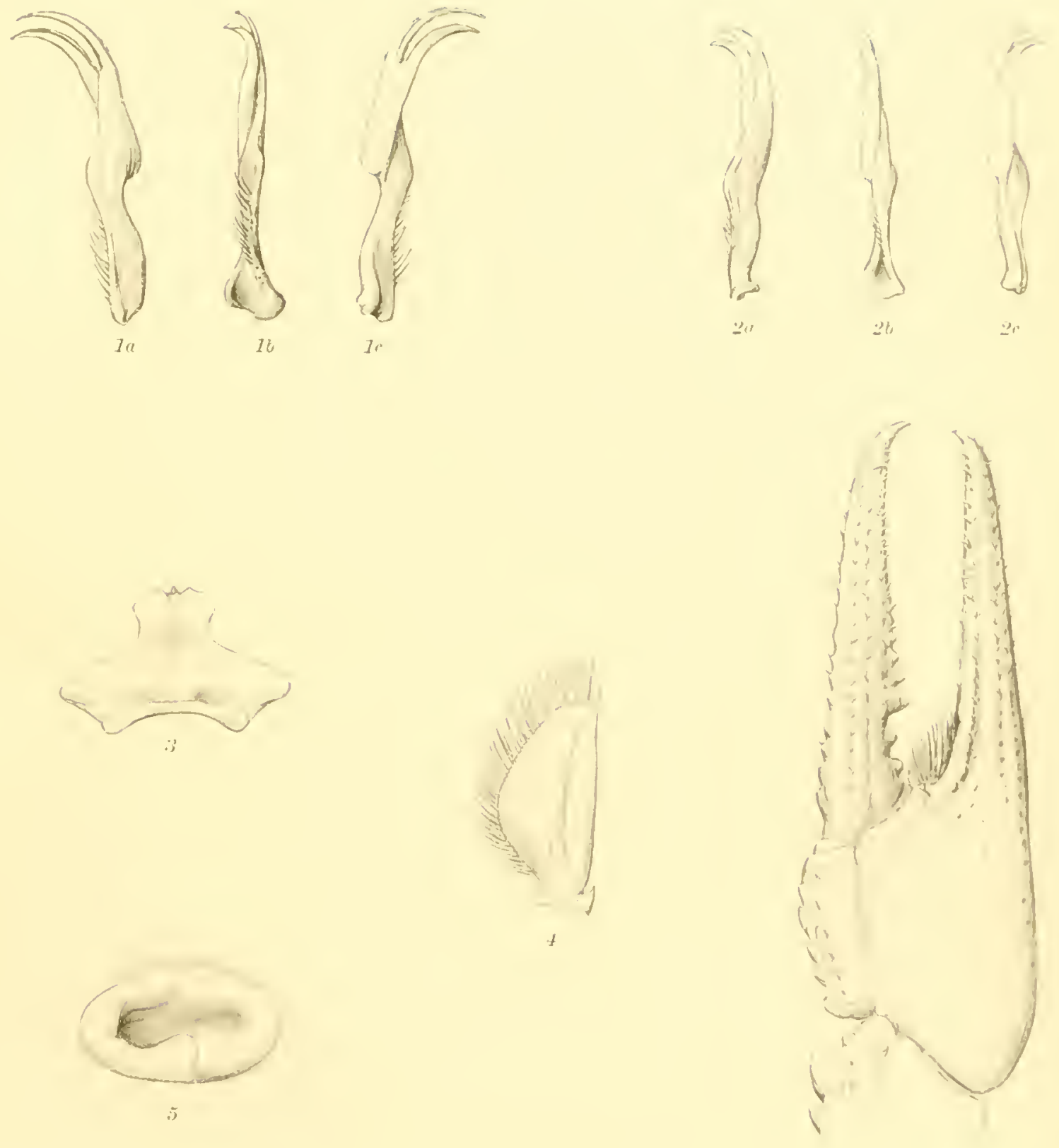

ILATE 7. 


\section{PLATE 7.}

Fig. 1.- Cambarus hagenianus Faxon. Muldon, Miss. Conopol of or. form I. 1a, outer siele, 1b, inner side, $1 c$, front.

Fig. 2.- Cambarus pellucidus (Tellkampf). Manmoth Cave, Ly. Conopod of or, form I. 2a, outer side, $2 b$, innel side, $2 c$, front.

Fig. 3.- Cambarus validus Faxon. Huntsville, Ala. Type. M. C. Z., No.301. Gonopod (o form I.). $3 a$, outer side, $3 b$, inner side, $3 c$, front.

Fig. 4.-Cambarus validus Faxon. Type. Antennal seale.

Fig. 5.- Astacus nigrescus fortis Faxon. or. Fall R., Fall City Mills, Cal. Type. U. S. N. M. Antemal seale.

Fig. 6.- Astacus gambeli connectens Faxon. o'. Snake R., Lpper Salmon Falls, Idaho. Type. U.S. N. MI., No. 23,096. Antenual scale.

Fig. 7.-- Cambarus hagenianus Faxon. q. Muldon, Miss. Annulus ventralis.

Fig. 8.- Camban valilus Faxon. o. Type. Epistoma.

Fig. 9.-Astacus nigrescens fortis Faxon. or. Type. Epistoma.

Fig. 10.- Astacus gambitic connecters Faxon. o'. Type. Epistoma. 
ILm. M[un. Comp. Yäl.

(ratales. Plate -.
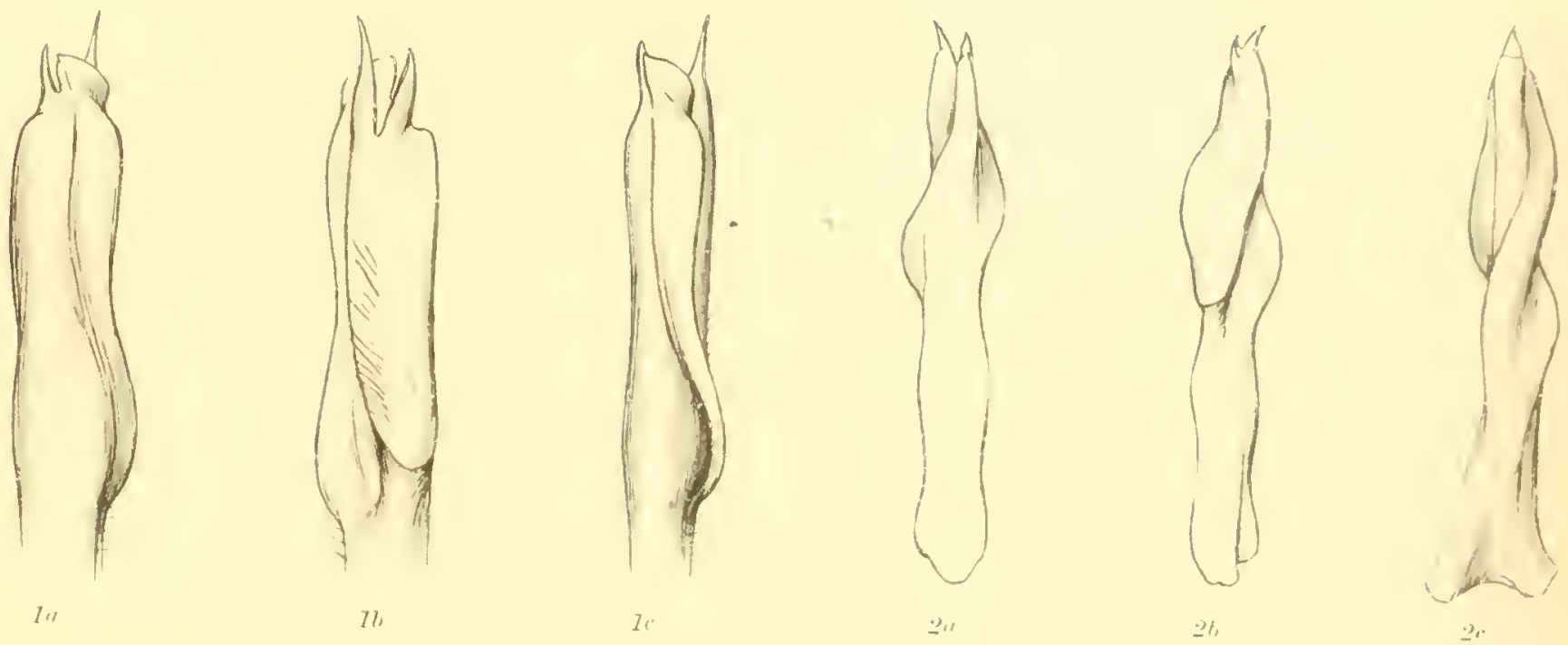
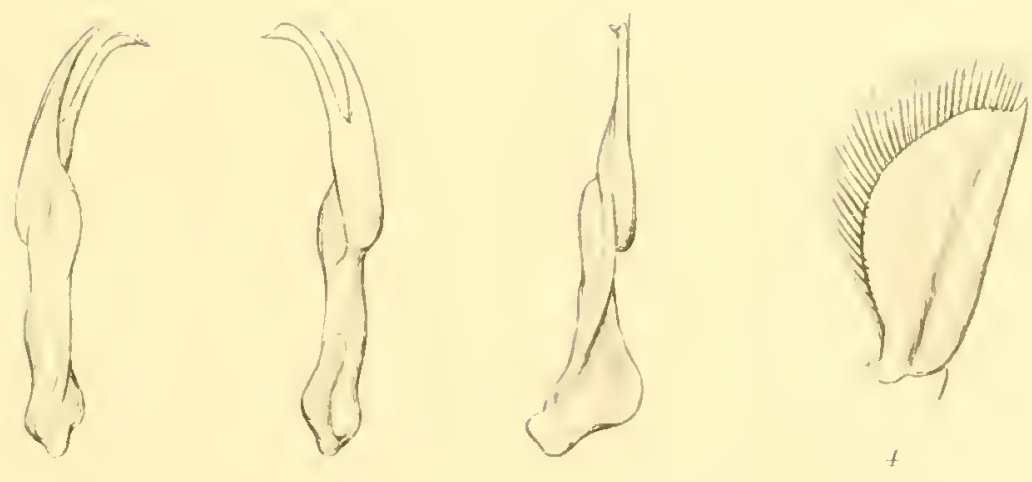

in

$3 \%$

ir<smiles>CCCCCCCCC</smiles><smiles>C1C2C3CC4C1C1C2C3C41</smiles>

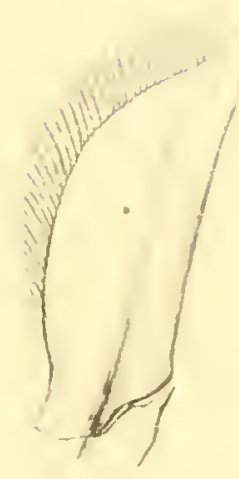

is

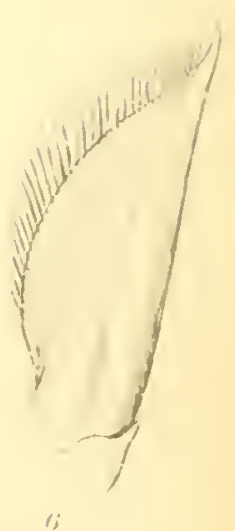

i,

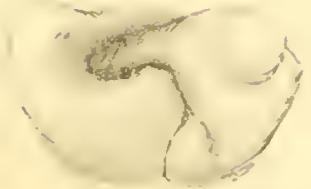

i 

PLATE 8. 


\section{PLATE 8}

Fig. 1. Lstucus astucus (Linné). - ج?. Leipzig, Germany. M. C. Z., No. 3403.

Fig. 1a.- Gononod of the same.

Fig. 16.- Chela of the sime.

Fig. 1c.-Antrinal seale of the same.

Fig. 1d. Anterior procens of the epistoma of the same.

Fig. 1e.-Profile of anterior end of rostrum of the same.

Fig. 1f- - Pleura of the second and third alydominal segments of the same.

Fig. 2.- Astucus prllipes italicus Faxon. o. Sarno R., Pompeii, Italy, June 10, 1900. Type. U. S. N. M., No. 28,638.

Fig. 24.-Cromolul of the same.

Fig. 2b.-Chuta of the same.

Fig. 2c- - Antemnal seale of the sume.

Fig. 2d.- Antrior process of the epistoma of the same.

Fig. 2e-- Profile of anterior end of rostrum of the sane.

Fig. 2f.- Plenra of the second and third abdominal segments of the same.

Fig. 3-Asmcus pallipes Lereboullet. or. Swone R., lyons, France. M. C. Z., No. 3,372.

- Fig. 3rt-Cunomud of the same.

Fig. 3h.-Cheliz of the same.

Fig. 3c- - Antenual srale of the same.

Fig. 3l.- Anterion process rif the epistoma of the same.

Fig. 3e- - Profile of anterior end of rostrum of the sume.

Fig. 3f.- Ploura of the second and thirt abdominal segments of the same. 

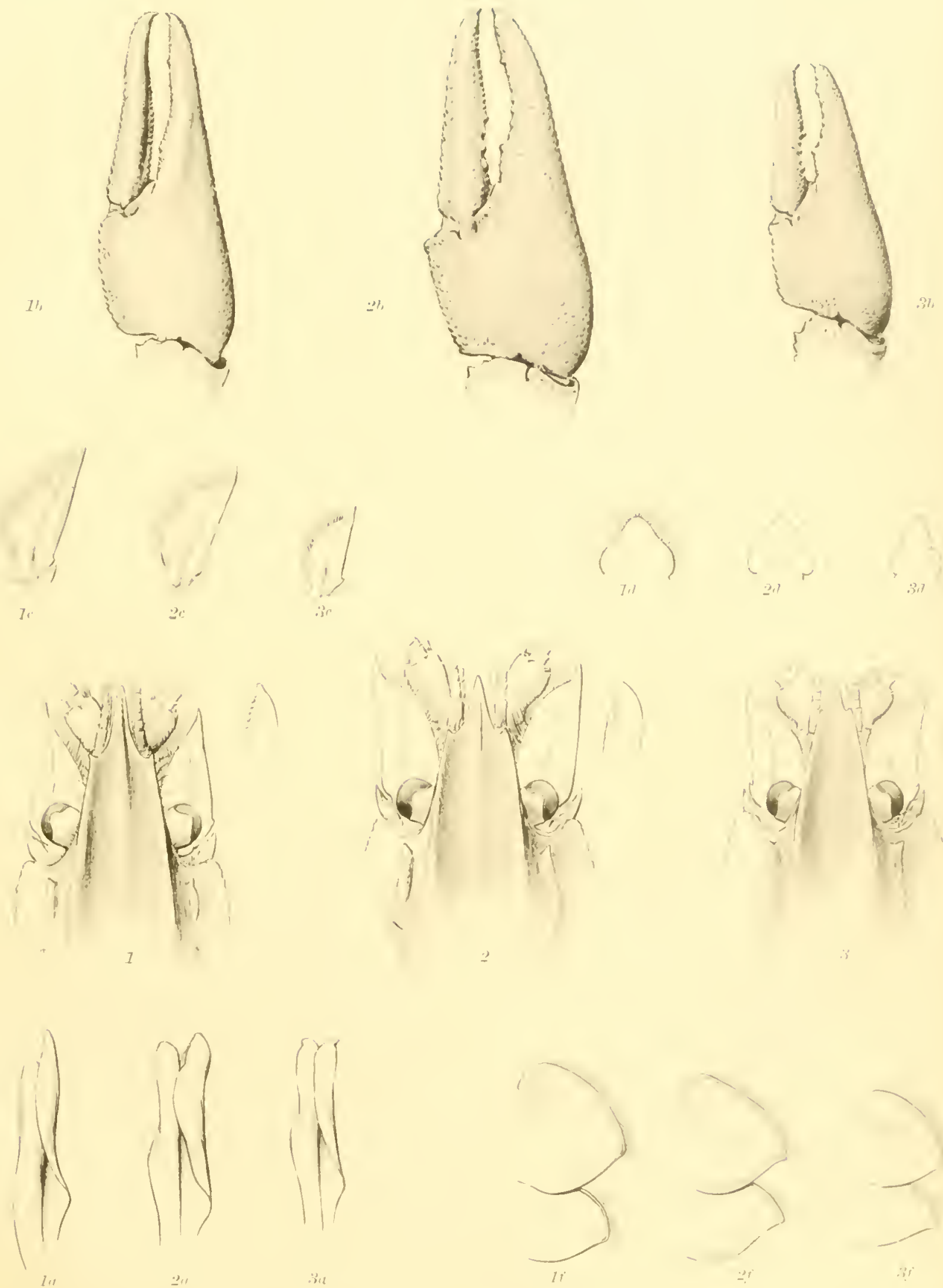

PLATE 9. 
PLATE 9.

Fig. 1.- Parastacus spunifrons (Plilippi)? Mus. d'Hist. Nat, Puris. $\quad \times 1$.

Fig. 2-Astacus nigresens fortis Faxon. o7. Type. Fall R., Fall City Mills, Cal., Aug. 29, 1895. U.S. A. M. Slightly enlarget. 

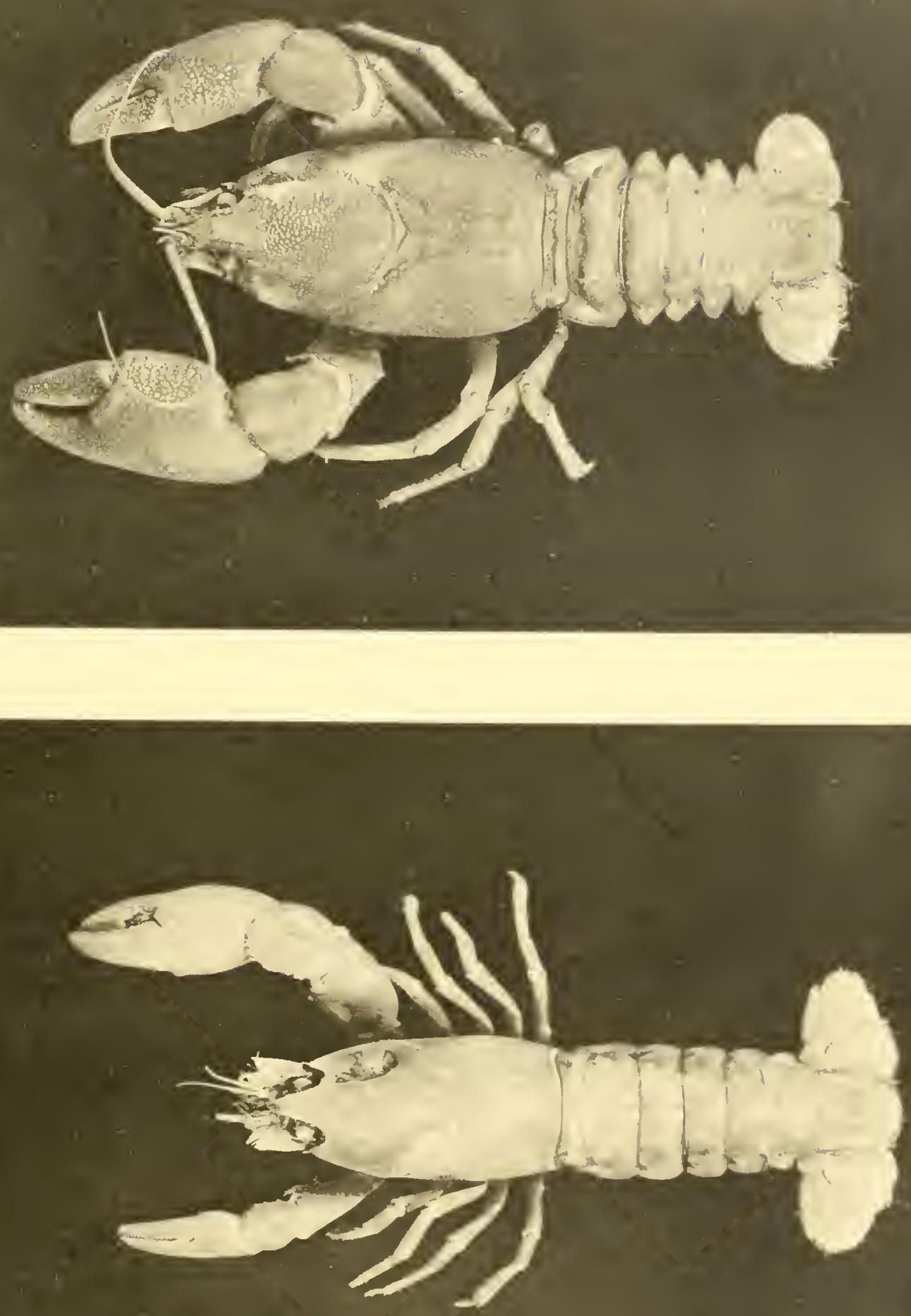

PLate 10. 
Fig. 1.-Astacus gambeliz connectens Faxon. os. Type, Snake R., Upper Salmon Falls, Idaho, Oct. 3, 1S94. U. S. N. M., No. 23,09f. Enlarged.

Fig. 2.- Astacus gambelii with most of the characters of A.g. connectens. O3. Mouth of St. Joe R., Coeur d'Alene Lake, Idaho. U. S. N. M. $\times 1$. 

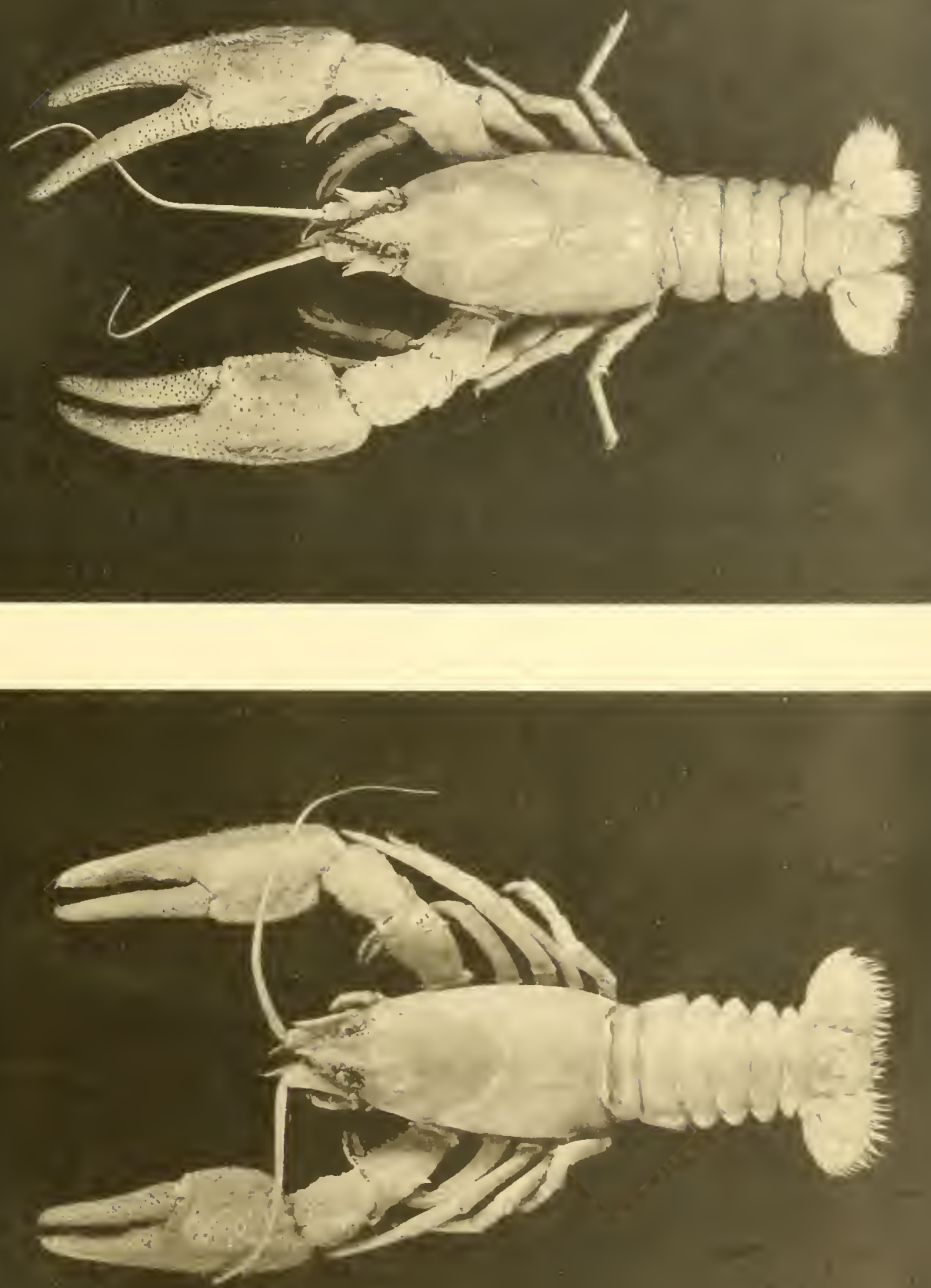

PLATE 11. 
PLATE 11.

Fig. 1.- Astacus hlamathensis Stimpson. or. Portland, Or. U.S.N.M., stightly enlarged. Sloning the chelipeds of normal shape.

Fig. 2.- Aslacus hlamathensis itimpson. of. Portland, Or. U.S. N. M., slightly reduced. Showing the ahromal, atavistic form of the regenerated claw of the left side. 

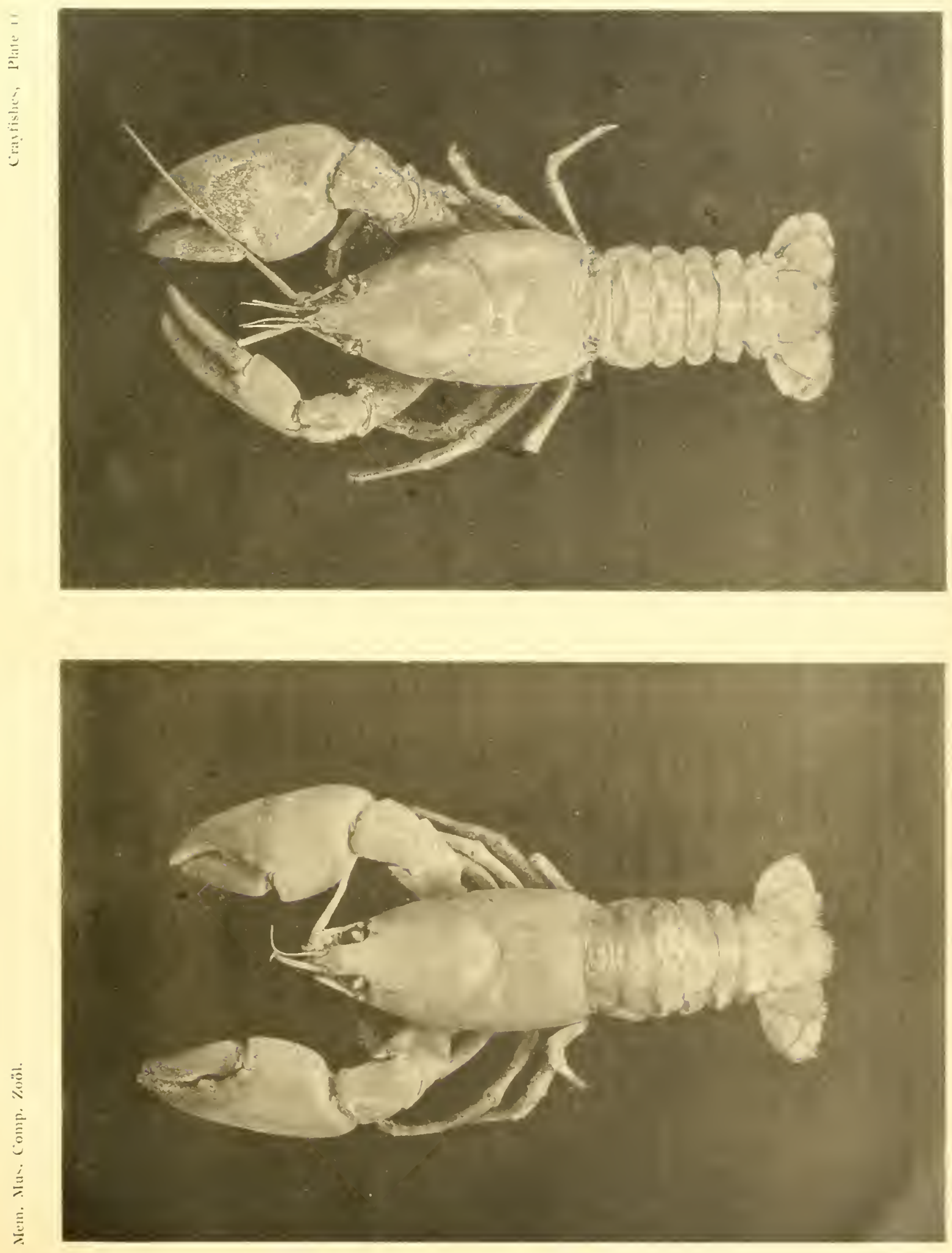

PLATE 12. 
PL_tTE 12.

Fig.--Astacus 7.lamathensis simpson. 3. Portland, Or. L. S. X. M. X 1. Both of the chelipeds are second growths, the leit the older.

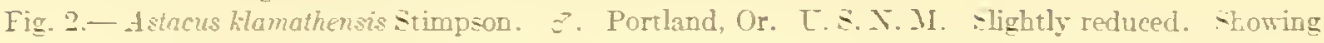
both claws regenerated, of full size. and nearly symmetrical: yet very different in shape from the normal claw as seen in Plate 11, Fig. 1. 

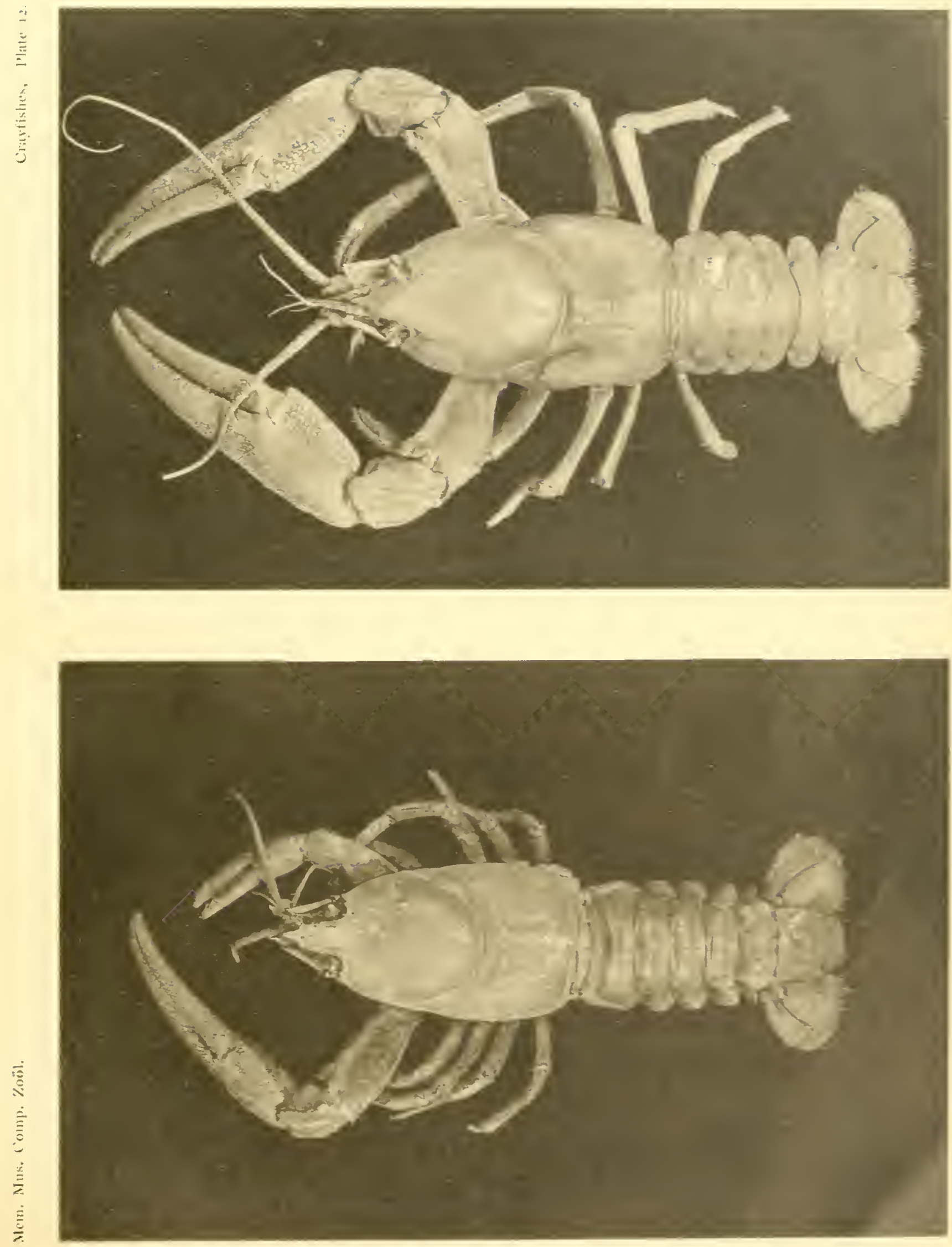

PLATE 13. 
PLATE 13.

Fig. 1.-Cambarus validus Faxon. O form I. Type. Huntsville, Ala. M. C. Z., No. 301. $\times 1 \frac{1}{2}$.

Fig. 2.-Cambarus bartonii veteranus Faxon. ơ, form I. Type. Indian Creek, Baileysville, IT. Va. Aug. 16, 1900. U.S. N. M., No. 25,020. Reduced. 

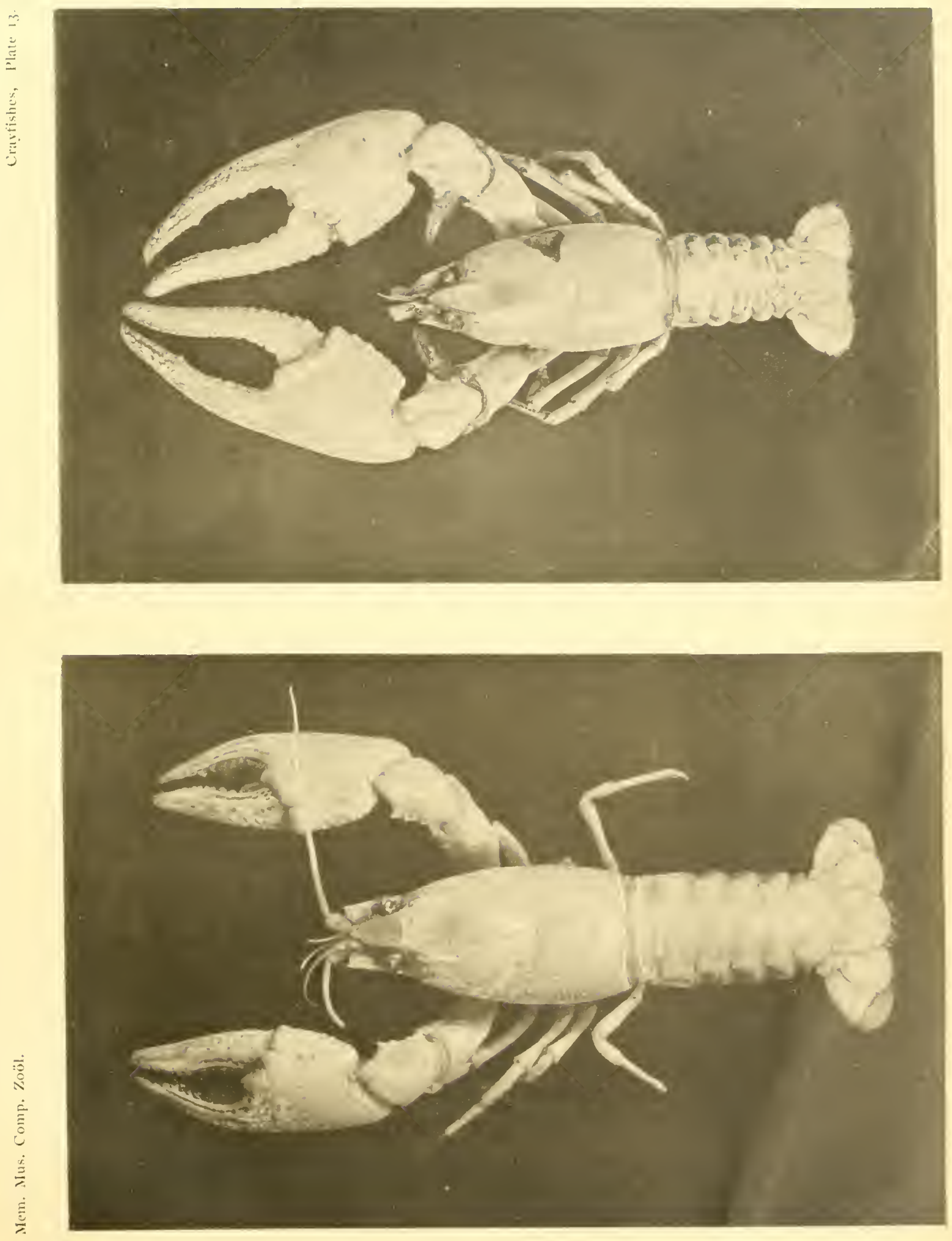




\section{PUBLICATIONS}

OF THE

\section{MUSEUII OF COMPARATIVE ZOÖLOGY AT HARVARD COLLEGE.}

There have been published of the Bulletin Vols. I. to LIV.; of the Memoirs, Fuls. I. to XXIV, and also Vols. XXVI, to XXIX., XXXI. to XXYIV., XXXYI. to XXXYII, XL1, and XLIV.

Tols. LT. to LTIII, of the Bulletin, and Fols. XXY., XXX., XXXY, XYXIX., XL., XLII., XLIII, XLV. to XLVIII. of the Menotrs, are now in course of publication.

1 price list of the publications of thr Mussum will be sent on application to the Dirretor of the Mussum of Comparative Zoölog!!, Cambridge, Mass.

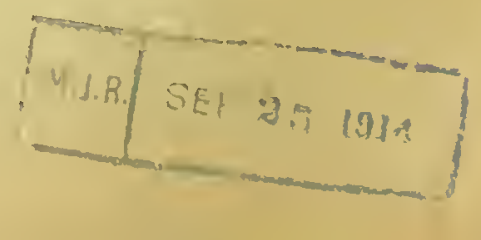








SMITHSONIAN INSTIUUTION LIBRARIES 